\title{
REVISION OF THE NEOTROPICAL GENUS PSEUDOXANDRA (ANNONACEAE)
}

\author{
PAUL J.M. MAAS \& LUBBERT Y.TH. WESTRA \\ Nationaal Herbarium Nederland, Utrecht University branch, W.C. van Unnikgebouw, \\ Heidelberglaan 2, 3584 CS Utrecht, The Netherlands
}

\section{SUMMARY}

A taxonomic revision is made of the Neotropical genus Pseudoxandra. This genus forms part of the Cremastosperma alliance which consists of Bocageopsis, Cremastosperma, Ephedranthus, Klarobelia, Malmea, Mosannona, Onychopetalum, Oxandra, Pseudephedranthus, Pseudomalmea, Pseudoxandra, Ruizodendron, and Unonopsis, all from the Neotropics. Within Pseudoxandra 22 species are recognized, four of which were described quite recently by the first author (Maas et al., 1986). Fourteen species are described here as new. Two dichotomous keys are provided, one for the genera of the Cremastosperma alliance, and the other for the species of Pseudoxandra. The species treatments include descriptions, geographical and ecological notes, distribution maps, synonymy, taxonomic notes, and vernacular names. A complete index of exsiccatae is included.

Parallel to the taxonomic revision, a leaf anatomical survey was made by E.-J. van Marle. One of the intriguing features in Pseudoxandra is the frequent presence of minuscule warts on the leaves in dried specimens, while fresh material does not show any such warts. Osteosclereids found in the mesophyll of most species are probably responsible for this feature.

This revision is meant as a precursor for a future Flora Neotropica treatment of the integral Cremastosperma alliance. Revisions of Klarobelia, Malmea s.s., Mosannona and Pseudomalmea, once constituting the genus Malmea s.l., were published earlier by Chatrou (1998). Treatments of other genera are under way, or planned for the near future.

Key words: Annonaceae, Pseudoxandra, leaf anatomy, osteosclereids, taxonomy.

\section{INTRODUCTION}

The genus Pseudoxandra was described in 1937 by the Swedish botanist and longtime authority on Annonaceae, Robert E. Fries. The same author (1959) placed the genus in the 'Asimina-Gruppe', an informal group with eight genera occurring in the Neotropics and six in Australia and/or Asia. Distinctive features mentioned by Fries for Pseudoxandra were (among others) short, articulate flower stalks with 2-several bracts below the articulation, but lacking bracts above it; small flowers, more or less globular in bud, with concave, rounded, imbricate petals; pointed carpels with one ovule and lateral placentation; and globular monocarps containing a single, somewhat flattened seed with equatorial furrow. In his original paper Fries also described the presence of a weak marginal vein in the leaf. In the opinion of the first author of the present paper the latter feature appears to be the most practical by which to recognize the genus, this in combination with a primary vein which is raised on the upper side of the lamina. No other Neotropical genus shares both character states (except for one or two species of Oxandra). 
In his first publication and at the same time taxonomic treatment of the genus (1937), as well as in his later overview (1959), Fries recognized a total of six species, namely P. leiophylla, P. coriacea (now a synonym of P. leiophylla), P. williamsii, P. guianensis (united in the meantime with the next species), P. lucida, and P. polyphleba.

The genus did not undergo any further revisional work in the period between 1937 and the middle 1980s. It was then that the present first author described four additional species (P. bahiensis, P. cuspidata, P. pacifica, and P. sclerocarpa; Maas et al., 1986). Monographic study of the genus started about 1990 and finally resulted in the present treatment which includes a total number of 22 species, 14 of them new (plus an additional incompletely known and thus not yet described species). If we include the four species from 1986, we count 18 newcomers, or more than $80 \%$ of the total number. This is much more than compared to other recently revised Neotropical genera of Annonaceae, e.g., Rollinia: 44 species of which 12 (c. 30\%) were new (Maas \& Westra, 1989; Maas, Westra \& Collaborators, 1992), and Duguetia: 93 species of which 28 (c. 30\%) are new (Maas, 1996, 1999; Maas, Westra \& Chatrou, in press). The remarkably high increase in number of species in Pseudoxandra is duly explained by a better understanding of this very uniformly looking genus. The species, while resembling each other, are quite distinct upon closer examination. This applies equally well to the largest and most problematical complex of $P$. lucida and $P$. polyphleba, that until recently we believed to constitute one polymorphic species. However, flower characters show them to be clearly different (small, glabrous flowers in P. polyphleba, and larger, hairy flowers in P. lucida). Moreover, $P$. polyphleba has coriaceous leaves, versus chartaceous leaves in $P$. lucida. The practical problem is that over $90 \%$ of collections of Pseudoxandra that are brought in lack flowers, and the difference between 'thick' (coriaceous) and 'thinner' (chartaceous) often is rather subtle, and depending upon personal judgement. This problematical group, like many of the other species, certainly needs additional field studies.

There have been several studies on the position of the genus Pseudoxandra within the family of Annonaceae.

1) Walker (1971) in his survey of pollen characters in the family distinguished the Malmea subfamily and within that the Malmea tribe. In the Malmea tribe he included 10 Neotropical genera, viz. Bocageopsis, Cremastosperma, Ephedranthus, Malmea s.1., Onychopetalum, Oxandra, Pseudephedranthus, Pseudoxandra, Ruizodendron, and Unonopsis, and one African genus: Annickia (Enantia Oliver, non Falconer [Sabiaceae]). Pseudoxandra appears to be unique in this tribe because of pollen in tetrads, and because some of the species have retained the primitive anasulcate condition characteristic of many of the older 'ranalean' dicots.

2) In 1992 Van Heusden published her survey of floral characters in Annonaceae, based on an intensive study of the flowers of most genera in the family. Pseudoxandra was placed by her in the Cremastosperma group, a group characterized by imbricate, often ciliate sepals and petals, and one basal to lateral ovule. The Cremastosperma group included the following genera: Cremastosperma, Ephedranthus, Malmea s.1., Oxandra, Pseudephedranthus, Pseudoxandra, and Ruizodendron.

3) In the same year a comparable survey was published by Van Setten and KoekNoorman, who investigated fruits and seeds of most genera of Annonaceae. They distinguished 16 informal groups within the family. Group 4 consisted of 5 Asian 
genera, viz. Enicosanthum, Neouvaria, Phaeanthus, Trivalvaria, and Woodiellantha and 7 Neotropical genera, namely Cremastosperma, Ephedranthus, Malmea s.1., Oxandra, Pseudephedranthus, Pseudoxandra, and Ruizodendron (the former Malmea complex at present includes four distinct genera, viz., Klarobelia, Malmea s.s., Mosannona, and Pseudomalmea; Chatrou, 1998). This group was defined by uni-ovulate carpels with mostly basal placentation (but lateral to apical in Pseudoxandra), seeds transversely striate to pitted, and endosperm ruminations peg-shaped to lamellate (Fig. 11f-h).

4) Doyle et al. (2000) performed a combined analysis of morphological and molecular $(r b c \mathrm{~L})$ data. They placed Pseudoxandra in the Malmeoid clade, together with the Neotropical genera Ephedranthus, Malmea, and Unonopsis, the African genus Annickia, and an Asian species of Polyalthia (P. sumatrana).

In short, the results of recent taxonomic investigations suggest that the Neotropical genera Cremastosperma, Ephedranthus, Klarobelia, Malmea, Mosannona, Onychopetalum, Oxandra, Pseudephedranthus, Pseudomalmea, Pseudoxandra, and Ruizodendron form a more or less natural group within the family. The three genera Bocageopsis, Onychopetalum, and Unonopsis, included by Walker in 1971, have become separated as a small group of their own in the studies on flowers and fruits in 1992 by Van Heusden and Van Setten \& Koek-Noorman, respectively. However, Doyle et al. in 2000 placed Unonopsis again into the larger group.

\section{MATERIAL AND METHODS}

Herbarium material was investigated from the following herbaria: A, AAU, B, BR, C, CAY, CEPEC, COAH, COL, CUVC, E, ECON, F, FHO, G, GB, GH, HUA, HUAM, IAN, INPA, JAUM, K, LE, LZ, M, MBML, MG, MICH, MO, MOL, NA, NY, OWU, OXF, P, RB, S, U, UB, UC, US, USM, USZ, VEN, W, WAG, WIS, WU, Z.

Measurements as a rule were made on dried material. Measurements on material in spirit are given between accolades \{\} ; measurements on living material are given between square brackets [ ].

Colour indications and descriptions of surface structures are based on dried material, unless stated otherwise. We have tried to give an indication of the density of the tiny warts so characteristic for dried Pseudoxandra leaves by using the following gradations: very densely (see Fig. 11b), densely, rather densely (see Fig. 17b), and sparsely.

\section{KEY TO THE NEOTROPICAL GENERA OF THE CREMASTOSPERMA ALLIANCE}

1a. Flowers and fruit axillary or sometimes terminal on a short, axillary shoot ... . 2

b. Flowers and fruit terminal, leaf-opposed, or supra-axillary . . . . . . . 13

2a. Primary vein raised (or rarely flat) on upper side of lamina $\ldots \ldots \ldots \ldots \ldots$

b. Primary vein impressed on upper side of lamina. . . . . . . . . . . 10

3a. Marginal vein of lamina distinct (except in P. spiritus-sancti); petals 4-15 mm long. - Tropical S America . . . . . . . . . . . . . Pseudoxandra

b. Marginal vein of lamina absent (except in Oxandra p.p.); petals 4-35 mm long 4 
4a. Lamina glaucous on the lower side; monocarps transversely ellipsoid, 1-seeded; petals 25-35 mm long. - W part of tropical S America ..... R Ruizodendron

b. Lamina of different colour, not glaucous, on the lower side; monocarps (longitudinally) ellipsoid to globose, 1 -several-seeded; petals 4-20 mm long . . . . 5 5

5a. Monocarps 1 or 2, sessile, 2-4-seeded; petals provided with an apical tail-like appendage, 4-8.5 mm long. - Tropical S America ........ Onychopetalum

b. Monocarps generally many more (up to 30), mostly distinctly stipitate, often 1-seeded; petals without an apical appendage, $2.5-20 \mathrm{~mm}$ long . . . . . . 6

6a. Lamina asymmetrical; petals $2.5-4.5 \mathrm{~mm}$ long; monocarps 1-seeded (except in B. pleiosperma), short-stipitate. - Tropical S America . . . . . . . Bocageopsis

b. Lamina symmetrical; petals mostly $>5 \mathrm{~mm}$ long; monocarps 1 -several-seeded,

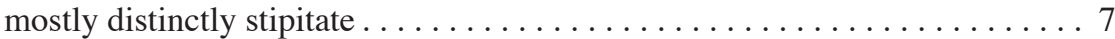

7a. Primary vein on upper side of lamina distinctly grooved. - Central America (Costa Rica, Panama), tropical S America............ Cremastosperma

b. Primary vein not grooved on upper side of lamina $\ldots \ldots \ldots \ldots \ldots \ldots$

8a. Venation of lamina raised on both sides, and very conspicuous; petals $10-15 \mathrm{~mm}$ long; seeds 25-30 mm long. - NW Amazon Region of Brazil, adjacent Vene-

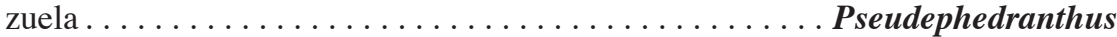

b. Venation of lamina, except for the midvein, not or only inconspicuously raised on the upper side; petals $4-10 \mathrm{~mm}$ long; seeds $8-20 \mathrm{~mm}$ long . . . . . . . 9

9a. Inflorescences consisting of single flowers or clusters of 2-several flowers, flower stalks articulate with a varying number of bracts below the articulation, and 0 -several bracts above the articulation; monocarps 1-seeded. - Mexico, Central America, the Greater Antilles, tropical S America . . . . . . . . Oxandra

b. Inflorescences often branched or, if single-flowered, the pedicel much longer than the contracted supporting short shoot, with 1 bract above the articulation; monocarps 1-several-seeded. - Central America, tropical S America. . . Unonopsis

10a. Venation of lamina distinctly impressed on upper side; monocarps long-stipitate (stipes 5-35 mm long); petals 8-12 mm long. - Tropical S America, mainly in

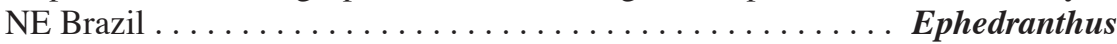

b. Venation of lamina flat on upper side; monocarps shortly to long-stipitate; petals

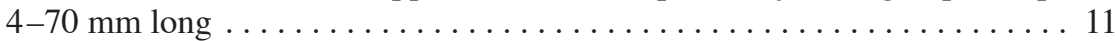

11a. Pedicels bearing about 3-6 very small bracts; stipes $<8 \mathrm{~mm}$ long; petals $4-8$ mm long. - Mexico, Central America, the Greater Antilles, tropical S America

Oxandra

b. Pedicels provided with 1 or 2 bracts; stipes $>10 \mathrm{~mm}$ or generally much longer (except Mosannona p.p.); petals 7-70 mm long . . . . . . . . . . . 12

12a. Pedicels without a bract above the articulation; petals $10-30 \mathrm{~mm}$ long, covering floral centre during development of flower. - Amazonian Brazil, Colombia,

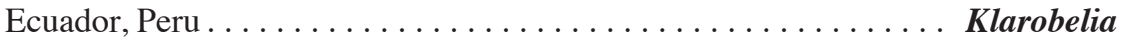

b. Pedicels with one bract above the articulation; petals 8-21 mm long, spreading during development of flower. - W part of tropical S America Pseudomalmea

13a. Primary vein raised (or rarely flat) on upper side of lamina; rumination of seeds broadly to narrowly lamellate; petals $10-70 \mathrm{~mm}$ long. - Central America, tropical

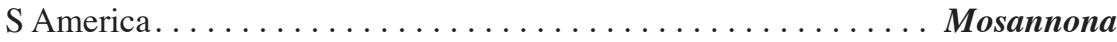

b. Primary vein impressed on upper side of lamina; rumination of seeds spiniform; petals 7-17 mm long. - Tropical S America 


\section{SYSTEMATIC TREATMENT}

\section{PSEUDOXANDRA - Map 1}

Pseudoxandra R.E. Fr. (1937) 222, f. 1-3; (1959) 65. - Lectotype (selected by R.E. Fries, 1959): Pseudoxandra leiophylla (Diels) R.E. Fr. [”Unonopsis leiophylla Diels].

Trees or shrubs $2.5-30 \mathrm{~m}$ tall, in P. cuspidata sometimes with whitish bark; leafy twigs terete, often covered with appressed, simple hairs when young, but very soon becoming glabrous. Leaves distichous, simple, entire, shortly petiolate, exstipulate; lamina medium-sized, mostly narrowly elliptic to narrowly oblong-elliptic, leaf index varying from 1.5-8, chartaceous to coriaceous, when dry often more or less densely covered with minute wartlike outgrowths (verruculose) on both sides, but most visibly so above, base acute to obtuse, often with angular to toothlike projections on either side (see Fig. 11), apex acuminate to acute, very rarely obtuse to rounded or even emarginate, upper side glabrous, rarely covered with appressed hairs, lower side glabrous or sometimes covered with appressed hairs, venation brochidodromous, primary vein raised above, prominent and generally rounded below (sharply protruding in P. cauliflora), secondary veins mostly indistinct, straight to curved, between $8-25$ on either side of the primary vein, angles with primary vein $45-90^{\circ}$, flat to raised above, united into a distinct marginal vein at $0.5-6 \mathrm{~mm}$ from the margin (except in P. spiritus-sancti), intersecondary veins commonly present, tertiary venation reticulate, flat to raised above. Inflorescences axillary, appearing simultaneously with new leaves or often developing on leafless branches, or rarely from the main trunk, consisting of a single flower or clusters of two to several flowers; flower stalks generally short, articulate, the part below the articulation (henceforth referred to as peduncle) covered with a varying number of caducous or more or less persistent bracts increasing in size towards the distal end, the upper part (henceforth referred to as pedicel) without bract. Indument: inflorescence, including peduncles, pedicels, outer side of bracts, sepals, and outer petals glabrous or sparsely to densely covered with appressed hairs (outer side of inner petals glabrous or only with a hairy ridge from base to apex). Flower buds depressed globose to globose. Flowers actinomorphic, bisexual, perianth consisting of one whorl of sepals and two whorls of petals; sepals three, imbricate, free or basally connate, thin, mostly much smaller than the petals, margins often ciliate; petals six, imbricate, free, thin, often cream to white, margins often ciliate, the outer ones often broadly ovate and slightly concave, the inner ones often strongly concave and somewhat reflexed at the apex; torus depressed ovoid; stamens many, spirally arranged, extrorse, filament very short, connective apex discoid, often with adaxially protruding edge (described earlier as 'obliquely truncate', Maas et al., 1986; Fig. 13f-h), glabrous; carpels few to many, spirally arranged, free, ovary 1-locular with 1 lateral to apical ovule, stigma obovoid to ovoid. Fruit apocarpous, composed of 1-30, free monocarps, often with persistent sepals; monocarps mostly globose, green, fleshy, maturing red, purple to almost black, 5-25 mm diam., mostly glabrous, apex apiculate (apicle $0.1-3 \mathrm{~mm}$ long) to rounded, wall $0.2-3 \mathrm{~mm}$ thick, stipes of monocarps 4-15 by 1-3 mm. Seed 1, lateral to apical, transversely ellipsoid to globose, glabrous, brown, foveolate, raphe flat, a shallow groove or sunken rib, aril absent, ruminations spiniform. 


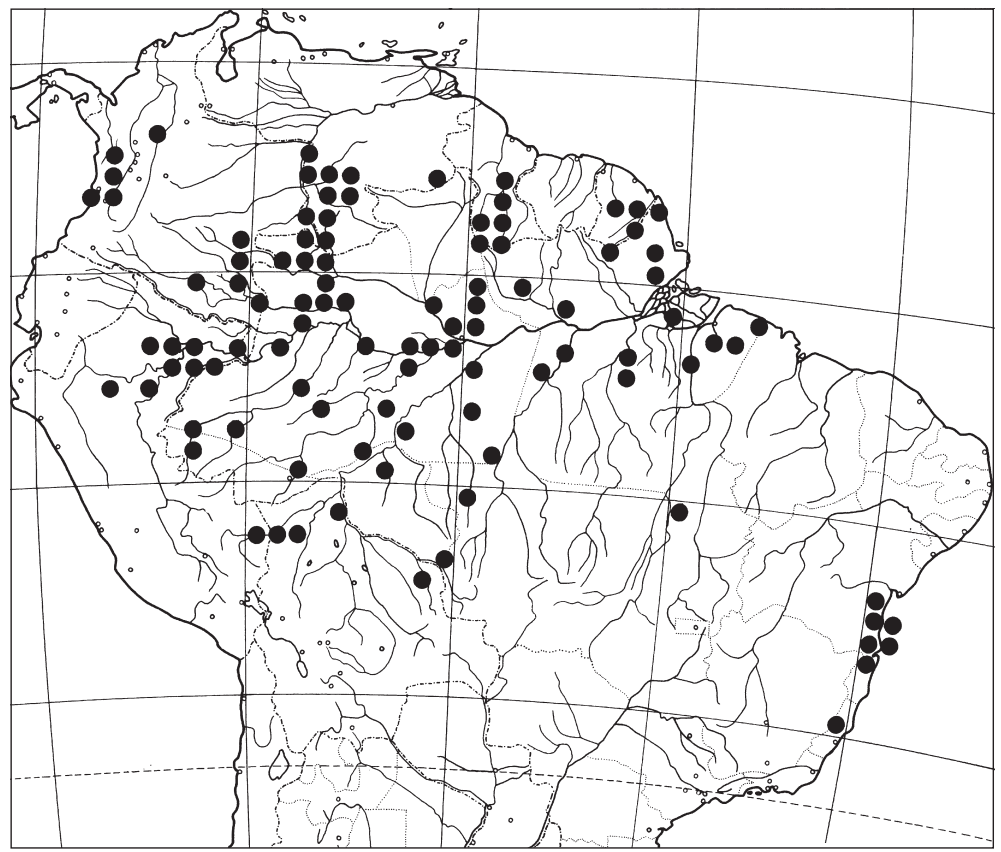

Map 1. Distribution of the genus Pseudoxandra R.E. Fr. in S America.

Chromosome number $-2 \mathrm{n}=18$ (P. polyphleba; Morawetz, pers. comm.).

Distribution - 22 species, restricted to tropical South America.

Habitat \& Ecology - In non-inundated forest, but some of the common species (P. lucida and P. polyphleba) occurring in temporarily inundated forest. At low elevations, but a few species reaching up to $950 \mathrm{~m}$.

Note - The genus was named Pseudoxandra by Robert E. Fries because of its general resemblance to Oxandra, another Neotropical genus of Annonaceae (from Old Greek 'oxys' = sharp, pointed, and 'aner' = man, i.e., stamen: referring to the sharply pointed connective apex in [part of] the latter genus).

\section{LEAF ANATOMY OF PSEUDOXANDRA}

(Erik-Jan van Marle)

\section{MATERIAL AND METHODS}

The collections studied are cited in the List of vouchers for leaf anatomical studies (Table 1). From these herbarium collections samples were taken from mature leaves at $1 / 3$ of the lamina length, as seen from the base. The removed leaf parts were rehydrated by boiling in water and were used for the preparation of transverse sections of the central part of the lamina including the primary vein, as well as cuticular macerations. All sections were bleached and stained with Astra-blue and Safranin. Cuticular macerations were put in equal volumes of acetic acid $100 \%$ and hydrogen acid $30 \%$ at $60{ }^{\circ} \mathrm{C}$ for several days, and stained with Sudan IV. 
Table 1. Vouchers for leaf anatomical studies.

\begin{tabular}{|c|c|c|c|c|c|}
\hline & Slide & Collector & & Slide & Collector \\
\hline P. acreana & B-1802 & Cid et al. 10570 & P. obscurinervis & B- 732 & Prance et al. 11468 \\
\hline P. atrata & B-1804 & Vásquez et al. 16888 & P. pacifica & B-1809 & A.H. Gentry et al. \\
\hline P. bahiensis & B-1798 & Amorim et al. 1193 & & & 40279 \\
\hline P. borbensis & B-1806 & Henderson et al. 355 & P. papillosa & B-1810 & Cid \& Lima 3781 \\
\hline P. cauliflora & B-1816 & Daly et al. 4424 & P. parvifolia & B-1811 & Berry et al. 6196 \\
\hline P. cuspidata & B-1799 & Berg et al. 757 & P. pilosa & B-1812 & Cid et al. 9925 \\
\hline \multirow[t]{2}{*}{ P. duckei } & B-1801 & W.A. Rodrigues \& & P. polyphleba & B- 588 & Krukoff 4882 \\
\hline & & D. Coêlho 7815 & P. revoluta & B-1813 & N. Arévalo et al. 74 \\
\hline P. leiophylla & B-1805 & Berry et al. 5449 & P. rionegrensis & B-1814 & Stevenson et al. 898 \\
\hline P. leiophylla & B-1807 & Amaral et al. 576 & P. sclerocarpa & B- 1800 & Cogollo et al. 1206 \\
\hline P. longipes & B-1808 & Monsalve B. 1168 & P. spiritus-sancti & B-1815 & Maas et al. 8835 \\
\hline P. lucida & B- 589 & A.C. Smith 2665 & P. vallicola & B-1817 & Juncosa 2137 \\
\hline P. lucida & B- 797 & Berg et al. P18462 & P.spec.nov. A & B-1803 & Murillo \& Román 616 \\
\hline
\end{tabular}

One specimen was taken from each species, only for P. leiophylla and P. lucida two specimens from each were studied. For $P$. williamsii insufficient material was available.

Minimum and maximum values are given in $\mu \mathrm{m}$, with extremes between brackets.

Examination was done with a Leitz Dialux microscope. Slides used for this study are deposited at the Nationaal Herbarium Nederland, Utrecht University branch.

For SEM photographs fragments of dried leaves were used (no additional drying was required). The fragments were mounted on stubs with double-sided sticking tape, and sputtercoated with gold using a Bal-tec SCD 005 sputtercoater. Photography was done with a JEOL JSM-5300 scanning electron microscope in combination with a SemAfore digital camera.

The terminology used is according to Metcalfe \& Chalk $(1979,1983)$.

$$
\text { RESULTS - Table } 2
$$

In surface view

Adaxial side - Indument mostly lacking or, if present, consisting of appressed or upright, uniseriate simple trichomes of 3-8 cells, 200-850 $\mu \mathrm{m}$ long, apical cell pointed. Cuticula present, smooth. Unspecialized epidermal cells $16-32$ by $12-23$ $\mu \mathrm{m}$, polygonal, anticlinal walls straight to strongly undulate.

Stomata present in very low density $\left(0-1 \mathrm{~mm}^{2}\right)$ in most species; if present, mainly along the leaf margin; about rounded, all paracytic with 2 subsidiary cells, 28-34 by 22-28 $\mu \mathrm{m}$, slightly sunken in P. atrata.

Crystals present in epidermis cells (as seen in macerations) of most species, as needles, rhombic crystals, star crystals, or druses. No crystals observed in P. obscurinervis, $P$. pilosa and one specimen of P. leiophylla.

Abaxial side - Indument present in about half of the species, consisting of appressed or upright simple, uniseriate trichomes, of 1-11 cells, 0.1-2 mm long, apical cell pointed. Cuticula mostly present, smooth. Unspecialised epidermal cells 19-44 by $12-24 \mu \mathrm{m}$, polygonal, anticlinal walls straight to strongly undulate. 


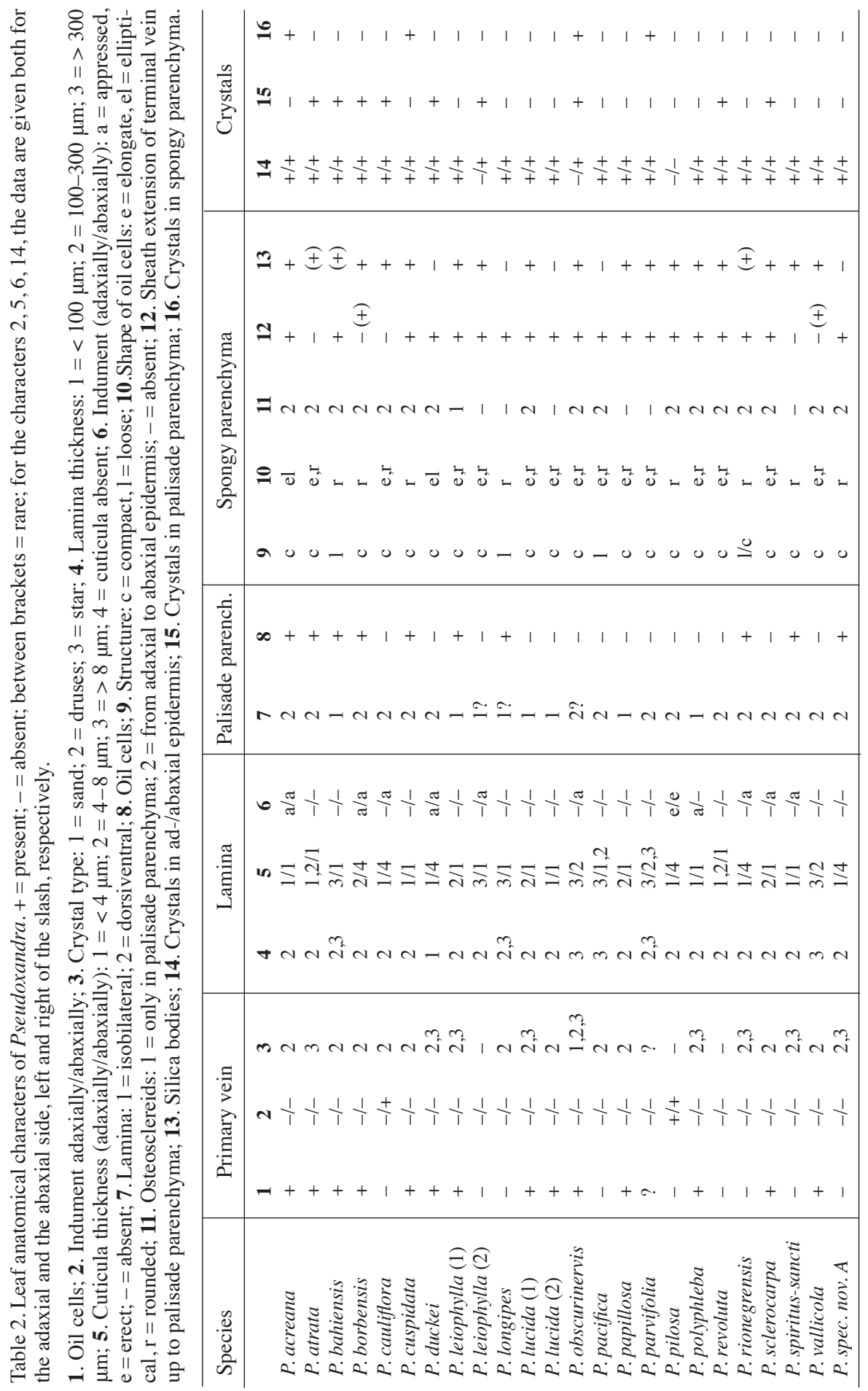



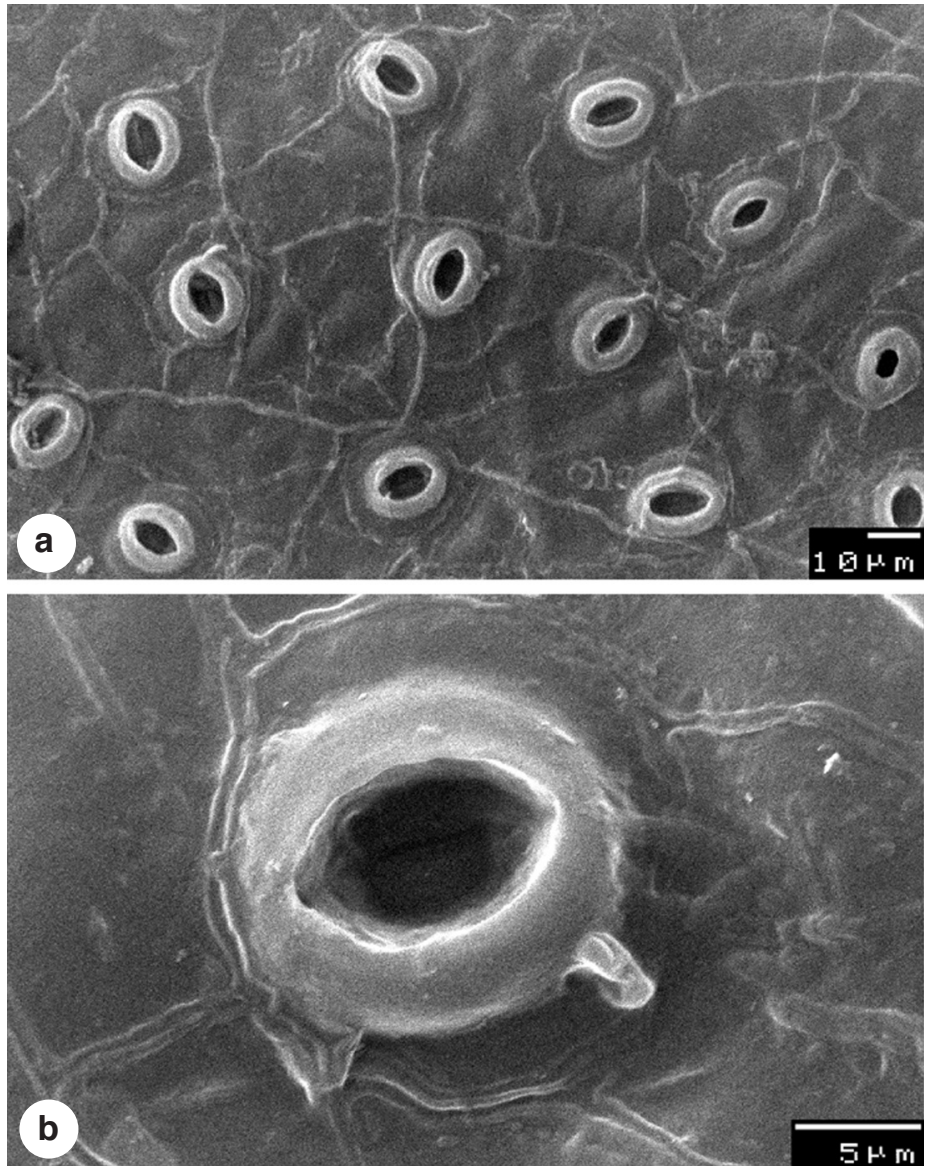

Fig. 1. Pseudoxandra papillosa Maas, SEM photographs. a. Stomata on abaxial surface, note guard cells with highly cutinized outer rim; b. close-up view of stoma (Cid \& Lima 3781).

Stomata paracytic with 2 subsidiary cells, about rounded, regularly distributed, $20-25$ by $17-23 \mu \mathrm{m},(150-) 315-385(-560) \mathrm{mm}^{2}$. In P. papillosa the guard cells have a highly cutinized outer rim (Fig. 1a, b).

Crystals present in epidermis cells (as seen in macerations) of all species but one, as needles, rhombic crystals, or druses. Only in P. pilosa no crystals observed.

\section{In transverse section (Fig. 2)}

Lamina dorsiventral or isobilateral, (50-)195-225(-335) $\mu \mathrm{m}$ thick. Cuticula adaxially $5-7.5 \mu \mathrm{m}$ thick, and abaxially $2-3.5 \mu \mathrm{m}$ thick, if present. Epidermis 1-layered on both sides, 16-22 $\mu \mathrm{m}$ thick adaxially, 9-13 $\mu \mathrm{m}$ abaxially. Stomata flat, but with heavy cutinized rim in $P$. papillosa (cf. Fig. 1).

Mesophyll consisting of 1-3(-4) layers of palisade parenchyma, 46-69 $\mu \mathrm{m}$ thick, and 3-8(-10) layers of usually compact spongy parenchyma. In isobilateral lamina abaxial palisade parenchyma 1-layered, 23-30 $\mu \mathrm{m}$ thick. Oil cells present in all species 

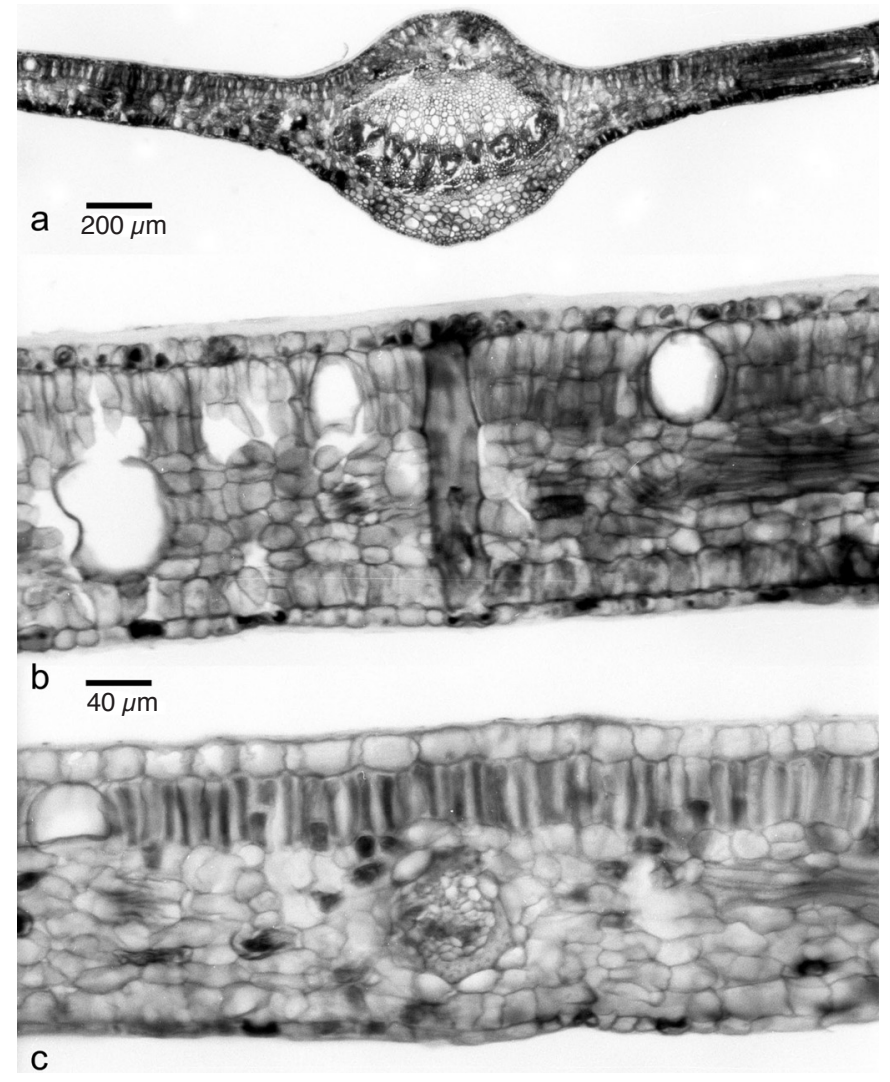

Fig. 2. Transverse sections of lamina. a, b: Pseudoxandra lucida R.E. Fr. a. Primary vein. b. isobilateral lamina with oil cells (idioblasts) and osteosclereid. - c: P. spiritus-sancti Maas. Dorsiventral lamina with secondary vein (a, b: A.C. Smith 2665; c: Maas et al. 8835).

in the spongy parenchyma and in about half of the species in the palisade parenchyma as well. Osteosclereids occurring in most species and reaching from the adaxial to the abaxial side (Fig. 2b). In most species also silica bodies occurring in the spongy parenchyma.

Primary vein (Fig. 1b) always raised adaxially and consisting of one vascular bundle surrounded by a continuous vascular cap of sclerenchymatous cells. Vascular bundle arc-shaped with continuous or interrupted phloem tissue at the abaxial side of the xylem tissue. In the ground tissue many stone cells, usually in clusters, and few to many oil cells present. Terminal veins collateral with sclerenchymatic caps with or without collenchymatic extensions reaching abaxially into the spongy parenchyma and adaxially up to the palisade parenchyma.

Crystals present in the epidermal cells and in the primary vein, mainly as needles, druses or star crystals of varying size (sand crystals observed in P. obscurinervis), or lacking; in mesophyll crystals usually absent. Rhombic crystals can be found around the terminal veins. 


\section{Discussion}

This first leaf anatomical survey covering (almost) the whole genus shows Pseudoxandra as rather homogeneous (Table 2) making it quite difficult, at least at this stage, to distinguish species. The results presented here are principally in agreement with those given by Van Setten \& Koek-Noorman (1986). In addition to crystal types reported in that paper, we also found star (or rosette) crystals in the primary vein and other parts of the lamina. It appears that the finely 'papillate' character of the lower side of dried leaves of P. papillosa is caused by the highly cutinized outer rim of the guard cells of the abaxial stomata (Fig. 1a, b).

One of the striking features of Pseudoxandra is the presence of tiny warts on the surface of dried leaves (when seen under a good hand lens or dissecting microscope). In contrast, fresh leaves or material preserved in spirit show a smooth surface, without a trace of warts. T. Lawrence (Kew, pers. comm.) suggested that osteosclereids are probably the cause of this phenomenon. Osteosclereids are found in most of the species of this genus, and they traverse the leaf blade from one side to the other. They are not or slightly branched with pointed tapering ends, and will press into the epidermis when the leaf dries, thus suggesting the presence of warts and supporting Lawrence's view.

No osteosclereids were found in the lamina of the investigated specimens of P.papillosa and P. parvifolia. In P. longipes some sclereids were found close to the primary vein only, but not elsewhere in the lamina. The two specimens examined of both $P$. leiophylla and $P$. lucida showed that there can be quite some variation in the shape of crystals within the same species, though not necessarily in quantity.

All characters examined vary a great deal, and independently from each other, making it impossible to delimit any species groups within the genus.

As said, from most species one specimen was examined, except for P.leiophylla and $P$. lucida from which two specimens each were studied. The variation range within those two species appeared comparable to the total variation as seen within the genus itself. This suggests that little or no taxonomical value can be attributed to leaf anatomical character states at the species level.

Pseudoxandra completely falls within the leaf anatomical variation range as known for the Neotropical genera (Van Setten \& Koek-Noorman, 1986), as well as Palaeotropical genera of the Annonaceae (Van Marle, unpublished results). Based on leaf anatomical data as far as known, it is not possible to come to an undisputable classification for Pseudoxandra.

\section{KEY TO THE SPECIES OF PSEUDOXANDRA}

1a. Persistent sepals $5-12 \mathrm{~mm}$ long; petals densely hairy $\ldots \ldots \ldots \ldots \ldots \ldots$

b. Persistent sepals $1-4 \mathrm{~mm}$ long; petals glabrous or hairy $\ldots \ldots \ldots \ldots \ldots . \ldots$

2a. Base of lamina cordate to truncate. - W Amazonian Brazil (non-inundated

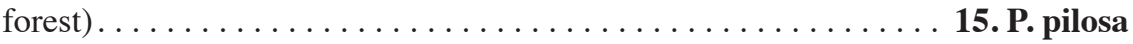

b. Base of lamina acute to obtuse $\ldots \ldots \ldots \ldots \ldots \ldots \ldots \ldots \ldots \ldots \ldots \ldots \ldots \ldots \ldots \ldots \ldots$

3a. Lamina $18-32$ by $5-11 \mathrm{~cm}$, densely hairy below. - Brazil (Acre) and Peru (Loreto)

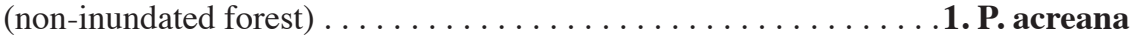

b. Lamina $9-20$ by $3-6 \mathrm{~cm}$, sparsely hairy, but soon glabrous, below . . . . . 4 4 
4a. Leaves 9-16 cm long, leaf index 2.5-3; angle of secondary veins with primary vein 50-65 . - C Amazonian Brazil near Manaus (non-inundated forest) . . . . .

7. P. duckei

b. Leaves 16-20 cm long, leaf index 4; angle of secondary veins with primary vein 45-50 ${ }^{\circ}$. - Amazonian Peru (non-inundated forest) . . . . . . 22. P. williamsii

5a. Lamina 5-7.5 cm long, apex obtuse to rounded, sometimes slightly emarginate. - Amazonian Venezuela (periodically inundated forest) . . . . 14. P. parvifolia

b. Lamina mostly (or at least partly) $\geq 10 \mathrm{~cm}$ long, apex acute to acuminate . . . 6

6a. Margins of base of lamina revolute over most of the length. - Amazonian Peru

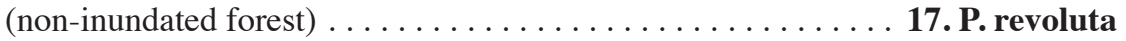

b. Margins of base of lamina not revolute (or inconspicuously so at the base only) 7

7a. Lamina $>6 \mathrm{~cm}$ wide (when in doubt, consult this lead first) . . . . . . . 8

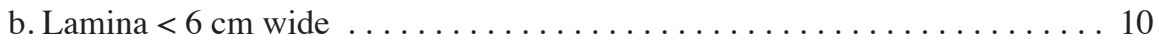

8a. Marginal vein running 2-5 $\mathrm{mm}$ from margin; corolla glabrous. - Pacific coast

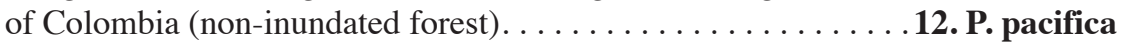

b. Marginal vein running $1-2 \mathrm{~mm}$ from margin; corolla hairy . . . . . . . . . 9

9a. Stipes of monocarps 1-5 mm long; lamina varying from densely to sometimes hardly verruculose. - Amazonian Colombia and adjacent Brazil (periodically inundated forest) $\ldots \ldots \ldots \ldots \ldots \ldots \ldots \ldots \ldots \ldots \ldots$. P. leiophylla

b. Stipes of monocarps 4-10 mm long; lamina densely to rather densely verruculose. - Throughout the Amazon Region and in adjacent Guyana (periodically inundated

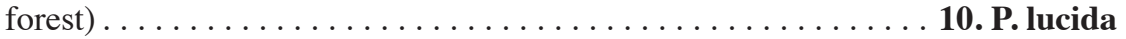

10a. Lamina not verruculose (or with few scattered verruculae), the lower side microscopically papillate (use good dissecting microscope magnifying about $50 \times$ ); monocarps 8-10 mm diam., stipes 1-2 mm long. - Amazonian Colombia and adjacent Brazil (periodically inundated forest) . . . . . . . . 13. P. papillosa

b. Lamina verruculose or sometimes smooth, the lower side not microscopically papillate; monocarps and stipes generally much larger (monocarps $8-25 \mathrm{~mm}$

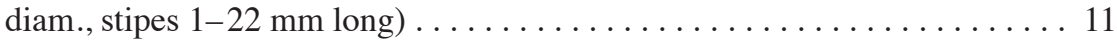

11a. Wall of monocarps $2-3 \mathrm{~mm}$ thick; base of lamina with distinct angular to toothlike projections on either side. - The Colombian state of Antioquia (non-inundated forest) . . . . . . . . . sclerocarpa

b. Wall of monocarps $<2 \mathrm{~mm}$ thick; base of lamina with or without angular or tooth-

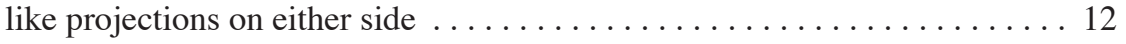

12a. Marginal vein running $>2 \mathrm{~mm}$ from margin (or absent) . . . . . . . . 13

b. Marginal vein running $<2 \mathrm{~mm}$ from margin . . . . . . . . . . . . . . . 19

13a. Lower side of lamina rather densely hairy; angle of secondary veins of lamina with primary vein $45-50^{\circ}$. - Amazonian Brazil (non-inundated forest) . . . . .

4. P. borbensis

b. Lower side of lamina sparsely hairy or glabrous; angle of secondary veins of lamina with primary vein $>50^{\circ} \ldots \ldots \ldots \ldots \ldots \ldots \ldots \ldots \ldots \ldots \ldots \ldots \ldots \ldots$

14a. Plant strictly cauliflorous; petiole 2-3(-4) mm long. - W Amazonian Brazil (non-inundated forest) $\ldots \ldots \ldots \ldots \ldots \ldots \ldots \ldots \ldots \ldots \ldots \ldots \ldots \ldots$. P. cauliflora

b. Plant flowering on older branches and/or among leaves; petiole $>3 \mathrm{~mm}$ long 15

15a. Secondary veins of lamina $6-12$ on either side of primary vein . . . . . . 16

b. Secondary veins of lamina 15-20 on either side of primary vein . . . . . . 17 
16a. Lamina coriaceous, strongly shiny; marginal vein present; monocarps $10-15$ mm diam.; stipes 20-30 mm long. - Pacific coast of Colombia (non-inundated forest $) \ldots \ldots \ldots \ldots \ldots \ldots \ldots \ldots \ldots \ldots \ldots \ldots \ldots \ldots \ldots \ldots \ldots \ldots$. P. longipes

b. Lamina chartaceous, not shiny; marginal vein absent; monocarps 14-25 mm diam.; stipes 5-15 mm long. - The Brazilian state of Espirito Santo (non-inundated

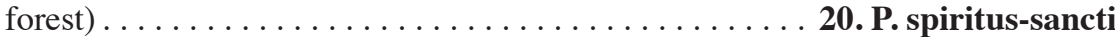

17a. Lamina chartaceous, its venation hardly visible to the naked eye (Fig. 5). - Amazonian Colombia and Peru (non-inundated forest) . . . . . . 2. P. atrata

b. Lamina coriaceous, its venation inconspicuous, but visible to the naked eye. 18

18a. Lamina brownish to green above when dry; wall of monocarps $1.2-1.8 \mathrm{~mm}$ thick, apicle 1-3 mm long. - The Brazilian state of Bahia (non-inundated forest). . . .

3. P. bahiensis

b. Lamina mostly blackish above when dry; wall of monocarps c. $1 \mathrm{~mm}$ thick, apicle c. $1 \mathrm{~mm}$ long. - Pacific coast of Colombia (non-inundated forest) . . . . . . . . .

21. P. vallicola

19a. Plant strictly cauliflorous; petiole $2-3(-4) \mathrm{mm}$ long. - W Amazonian Brazil

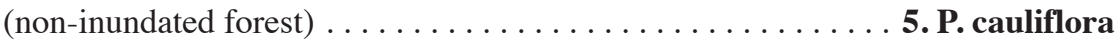

b. Plant flowering on older branches and/or among leaves; petiole generally much

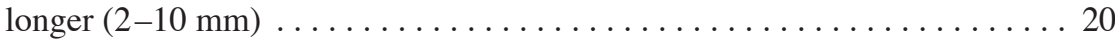

20a. Marginal vein running $0.5-1 \mathrm{~mm}$ from margin; bark sometimes whitish; leaf apex abruptly acuminate. - Guyana, French Guiana, and adjacent Brazil (noninundated forest $) \ldots \ldots \ldots \ldots \ldots \ldots \ldots \ldots \ldots \ldots \ldots \ldots \ldots \ldots \ldots \ldots \ldots$. cuspidata

b. Marginal vein running $>1 \mathrm{~mm}$ from margin, or absent; bark in shades of grey, never whitish; leaf apex gradually acuminate or acute $\ldots \ldots \ldots \ldots \ldots 21$

21a. Corolla densely hairy (unknown in P. rionegrensis) . . . . . . . . . . 22

b. Corolla glabrous (unknown in P. rionegrensis) . . . . . . . . . . . 24

22a. Wall of monocarps c. $1 \mathrm{~mm}$ thick. - The Upper Rio Negro region of Brazil (Amazonian caatinga forest) $\ldots \ldots \ldots \ldots \ldots \ldots \ldots \ldots$ 18. P. rionegrensis

b. Wall of monocarps $<0.5 \mathrm{~mm}$ thick $\ldots \ldots \ldots \ldots \ldots \ldots \ldots \ldots \ldots \ldots$

23a. Fruiting pedicels $4-8 \mathrm{~mm}$ long; stipes of monocarps $1-5 \mathrm{~mm}$ long; seeds $4-9$ by 7-9 mm. - Amazonian Colombia and adjacent Brazil (periodically inundated forest $\ldots \ldots \ldots \ldots \ldots \ldots \ldots \ldots \ldots \ldots \ldots \ldots \ldots \ldots \ldots \ldots$. P. leiophylla

b. Fruiting pedicels 5-15 mm long; stipes of monocarps 4-10 mm long; seeds 8-12 by $9-11 \mathrm{~mm}$. - Throughout the Amazon Region and in adjacent Guyana (periodically inundated forest $) \ldots \ldots \ldots \ldots \ldots \ldots \ldots \ldots \ldots \ldots \ldots \ldots$ 10. P. lucida

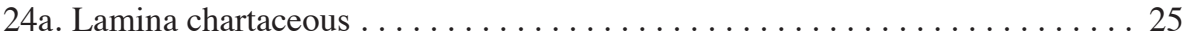

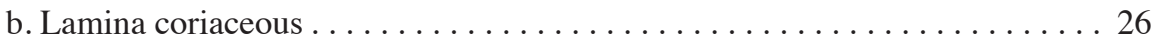

25a. Marginal vein present; monocarps $10-15 \mathrm{~mm}$ diam., wall $<0.3 \mathrm{~mm}$ thick; stipes to $4 \mathrm{~mm}$ long. - Throughout the Amazon Region (periodically inundated forest) .

16. P. polyphleba

b. Marginal vein absent; monocarps 14-25 mm diam., wall 1-2 mm thick; stipes 5-15 mm long. - The Brazilian state of Espirito Santo (non-inundated forest) .

20. P. spiritus-sancti

26a. Lamina dark blackish brown above when dry; fruiting pedicels 5-6 mm long. - Central Amazonian Brazil (non-inundated forest) . . . . 11. P. obscurinervis

b. Lamina green to brown above when dry; fruiting pedicels 10-12 mm long. . 27 


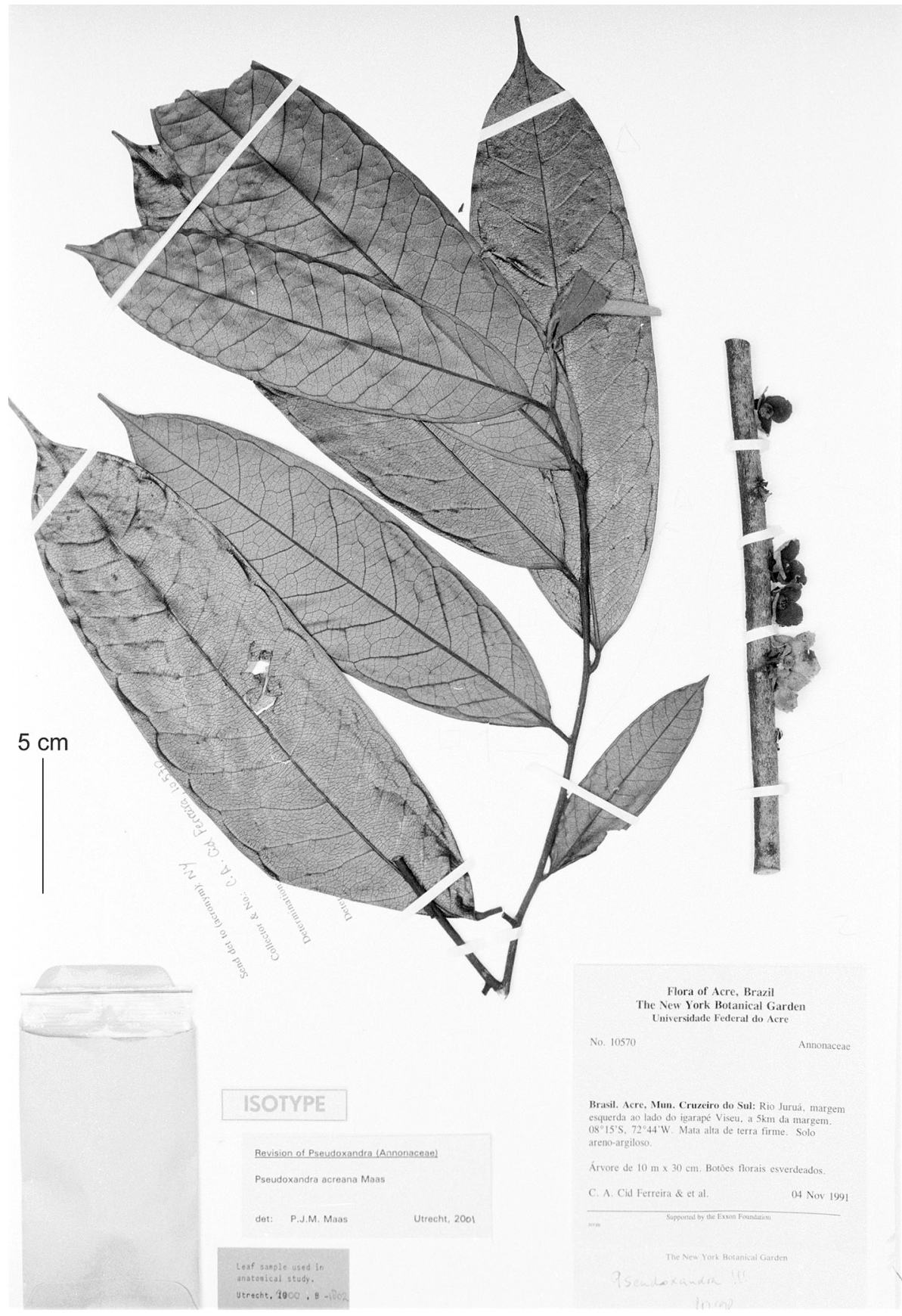

Fig. 3. Pseudoxandra acreana Maas. Holotype specimen (Cid et al. 10570, U). 
27a. Monocarps 8-12 mm diam., wall c. $1 \mathrm{~mm}$ thick; stipes 5-7 $\mathrm{mm}$ long; base of lamina with vague angular projections on either side. - The Upper Rio Negro region of Amazonian Brazil (non-inundated forest) . . . . . 18. P. rionegrensis

b. Monocarps 15-18 mm diam., wall 1.2-1.8 mm thick; stipes 5-20 mm long; base of lamina with distinct angular to toothlike projections on either side. - The Brazilian state of Bahia (non-inundated forest) ......... 3.P. bahiensis

\section{Pseudoxandra acreana Maas, spec.nov. - Fig. 3, 4; Map 2}

Pseudoxandrae duckei valde affinis, sed ab ea differt foliis majoribus lucidis. - Typus: Cid et al. 10570 (holo U; iso NY), Brazil, Acre: Mun. Cruzeiro do Sul, Rio Juruá, Igarapé Viseu, 4 Nov. 1991.

Tree 8-10 m tall, c. $30 \mathrm{~cm}$ diam.; young twigs densely covered with appressed, greyish hairs, soon glabrous. Leaves: petiole 5-10 mm long, 1-3 mm diam.; lamina narrowly oblong-elliptic, $18-32$ by $5-11 \mathrm{~cm}$ (leaf index 2.7-3.6), chartaceous, sparsely verruculose, shiny to slightly so, brown to brownish green above, brown below, sparsely covered with appressed hairs and some erect curly hairs above, soon glabrous, densely covered with appressed hairs to $2 \mathrm{~mm}$ long and erect, curly hairs to $0.3 \mathrm{~mm}$ long below, tardily glabrescent, base acute to obtuse, with indistinct to rather distinct angular projections on either side, apex abruptly and long-acuminate (acumen 5-20 $\mathrm{mm}$ long), secondary veins distinct, straight, $12-16$ on either side of

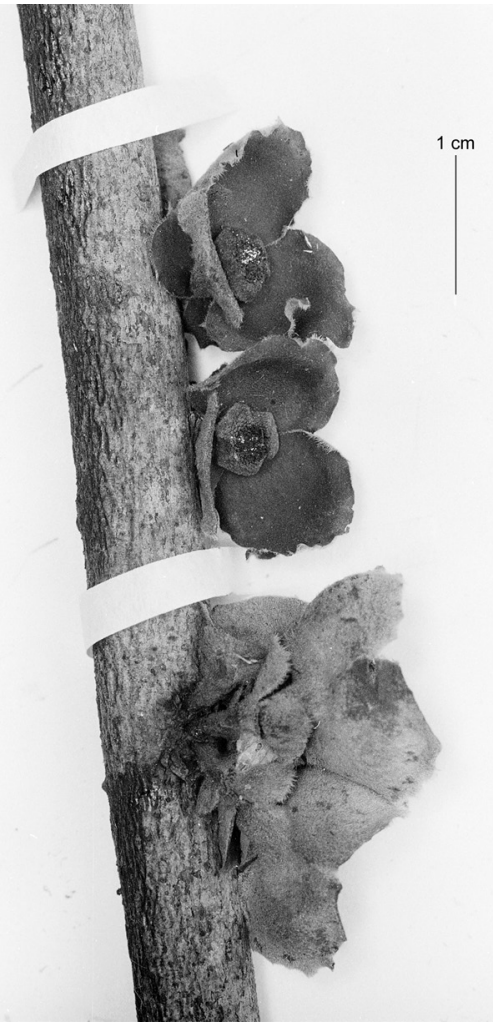
primary vein, prominent above, angles with primary vein $55-65^{\circ}$, smallest distance of marginal vein from margin 1-4 mm. Inflorescences 1-3-flowered, produced from leafless branches; peduncles 3-5 $\mathrm{mm}$ long, fruiting peduncles to $15 \mathrm{~mm}$ long; bracts $3-5$, broadly ovate, 5-10 $\mathrm{mm}$ long, outer side densely covered with appressed, grey hairs; pedicels 2-5 mm long, 1-3 $\mathrm{mm}$ diam., fruiting pedicels to $4 \mathrm{~mm}$ diam.; sepals broadly ovate, $8-10$ by $8-12 \mathrm{~mm}$, outer side densely covered with appressed, grey hairs; petals green in vivo, outer ones broadly ovate, $7-9$ by $10-11 \mathrm{~mm}$, inner ones concave, broadly ovate, $6-7$ by c. $10 \mathrm{~mm}$, outer side of outer petals densely covered with appressed, grey hairs, inner ones only hairy along the middle; stamens 2-3.5 mm long, connective appendage $0.5-0.7$ by $0.1-0.2 \mathrm{~mm}$; carpels sparsely covered with appressed hairs. Monocarps 20-30, green in vivo, dark brown in sicco, globose, $10-16 \mathrm{~mm}$ diam., apex rounded, with a slightly eccentric

Fig. 4. Pseudoxandra acreana Maas. Holotype specimen, close-up view of flowers (Cid et al. 10570, U). 


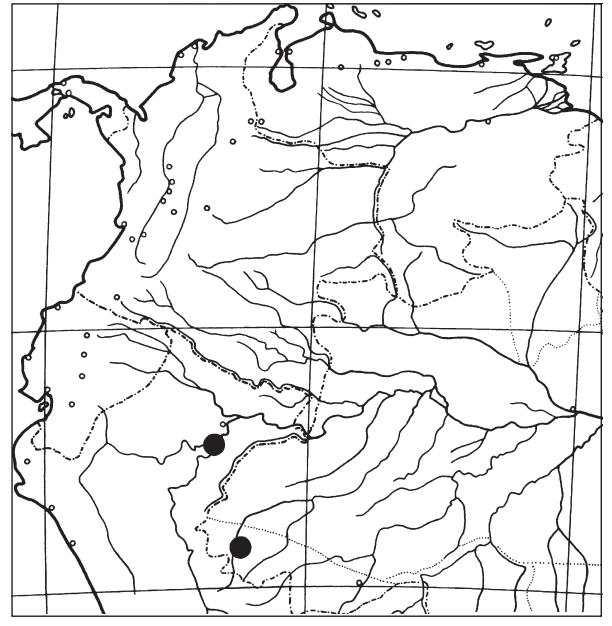

Map 2. Distribution of Pseudoxandra acreana Maas.

apicle $<0.1 \mathrm{~mm}$ long, wall c. $0.5 \mathrm{~mm}$ thick, stipes $8-10$ by $1-2 \mathrm{~mm}$; fruiting receptacle depressed ovoid, $8-10 \mathrm{~mm}$ diam. Seeds transversely ellipsoid, c. 11 by $7-8 \mathrm{~mm}$, dark brownish black to brown.

Distribution - W Amazonian Brazil (Acre) and the Peruvian state of Loreto.

Habitat \& Ecology - In non-inundated forest, on clay or sandy clay soil. At low elevations, up to $170 \mathrm{~m}$. Flowering: October and November; fruiting: June and October.

Vernacular name - Peru: Carahuasca.

Note - Pseudoxandra acreana is very close to $P$.duckei and $P$. williamsii, differing by larger, more shiny and densely hairy leaves.

Other specimens examined:

PERU. Loreto: Caserio Florida, Río Marañon, c. 8 km above Nauta, Rimachi Y. 4462 (K, MO, NA, NY).

BRAZIL. Acre: Mun. Cruzeiro do Sul, Igarapé Humaitá, affluent of Rio Juruá, behind Colocação Dois Portos, Cid et al. 10447 (HPZ, INPA, NY, U). Amazonas: Mun. Atalaia do Norte, Rio Javari, Paumarí, Cid. et al. 9878 (INPA).

\section{Pseudoxandra atrata Maas, spec. nov. - Fig. 5; Map 3}

A speciebus ceteris huius generis divergens foliis in statu sicco atratis dense verruculosis venis haud visibilibus. - Typus: Vásquez \& Jaramillo 14419 (holo MO; iso OWU), Peru, Loreto: Prov. Maynas, Allpahuayo, Estación Experimental del Instituto de Investigaciones de la Amazonía Peruana (IIAP), 39 km SW of Iquitos, 130 m, 19 Oct. 1990.

Tree 10-20 m tall, 8-20 cm diam.; young twigs glabrous. Leaves: petiole 3-8 $\mathrm{mm}$ long, $1-1.5 \mathrm{~mm}$ diam.; lamina narrowly oblong-elliptic, $10-17$ by $3-6 \mathrm{~cm}$ (leaf index $2.5-3.3$ ), chartaceous, very densely verruculose, not shiny, blackish to greyish black above, blackish to greyish black below, glabrous above, very sparsely covered with appressed hairs to $1 \mathrm{~mm}$ long below to glabrous, base acute to obtuse, without or with 2 vague angular to toothlike projections on either side, apex long-acuminate (acumen $10-15 \mathrm{~mm}$ long), secondary veins indistinct, straight, $15-20$ on either side of primary vein, very slightly prominent above, angles with primary vein $70-75^{\circ}$, smallest distance 


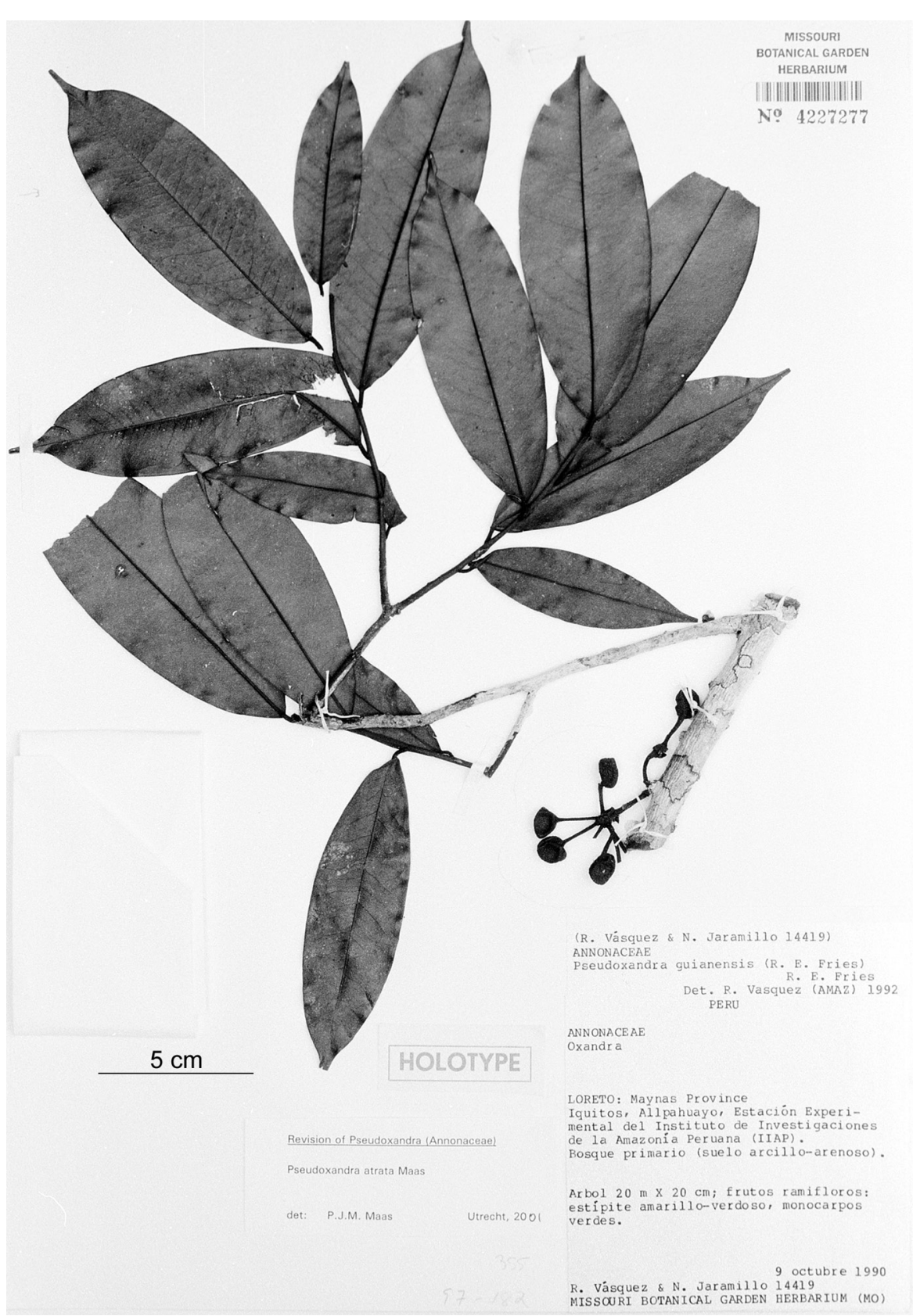

Fig. 5. Pseudoxandra atrata Maas. Holotype specimen (Vásquez \& Jaramillo 14419, MO). 


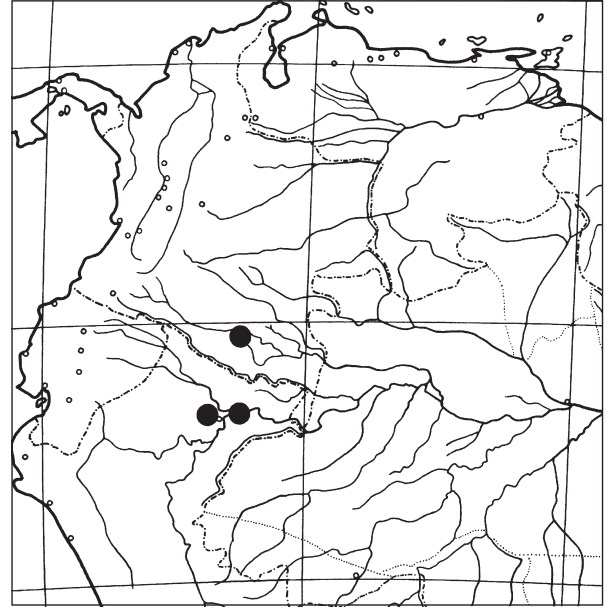

Map 3. Distribution of Pseudoxandra atrata Maas.

of marginal vein from margin 2-2.5 mm. Inflorescences 1- or 2-flowered, produced from leafless branches. Flowers not known. Fruiting peduncles $2-3 \mathrm{~mm}$ long; bracts 2 or 3, depressed ovate, 1-3 mm long, outer side rather densely covered with appressed hairs to glabrous; fruiting pedicels $10-14 \mathrm{~mm}$ long, 1-1.5 mm diam.; sepals broadly to shallowly ovate-triangular, $2-4$ by $3-5 \mathrm{~mm}$, outer side glabrous; petals, stamens, and carpels not seen. Monocarps 3-20, green in vivo when young, blackish in sicco, irregularly subglobose, $8-10$ by $6-7 \mathrm{~mm}$, apex rounded, wall c. $0.5 \mathrm{~mm}$ thick, stipes yellowish green, 12-13 by $1 \mathrm{~mm}$; fruiting receptacle depressed ovoid, c. $5 \mathrm{~mm}$ diam. Fully grown seeds not seen.

Distribution - Amazonian Colombia and Peru.

Habitat \& Ecology - In non-inundated forest, on clayey or sandy soil. At elevations up to $140 \mathrm{~m}$. Flowering time unknown; young fruits produced in June and October.

Notes - Pseudoxandra atrata is easily recognizable by its blackish, densely verruculose leaves with almost invisible veins. The material studied is very incomplete, flowers are lacking and only young monocarps were available for study.

This species was identified as P. guianensis by Vásquez (1997: 104).

Other specimens examined:

Colombia. Amazonas: Río Caquetá, 700 m below Isla Mariñame, Brand et al. 1504 (COAH); Río Caquetá, $2 \mathrm{~km}$ above Quebrada del Quinche, Urrego G. et al. 1040 (COAH).

PERU. Loreto: Prov. Maynas, Mishana, Río Nanay, halfway between Iquitos and Santa Maria de Nanay, 140 m, Gentry \& Aronson 25296 (MO, U); Prov. Maynas, Allpahuayo, Estación Experimental del Instituto de Investigaciones de la Amazonía Peruana (IIAP), $39 \mathrm{~km} \mathrm{SW}$ of Iquitos, $130 \mathrm{~m}$, Gentry et al. 61898 (MO); Prov. Maynas, Las Amazonas, Explor Napo Camp (Sucusari), Vásquez et al. $16888(\mathrm{MO})$.

\section{Pseudoxandra bahiensis Maas - Map 4}

Pseudoxandra bahiensis Maas, in Maas et al. (1986) 265, f. 12e, f, 13. - Type: Mori et al. 10240 (holo CEPEC; iso G, K, MG, MO, NY, RB), Brazil, Bahia: Mun. Uruçuca, new road from Uruçuca to Serra Grande, 28-30 km from Uruçuca, 17 July 1978. 


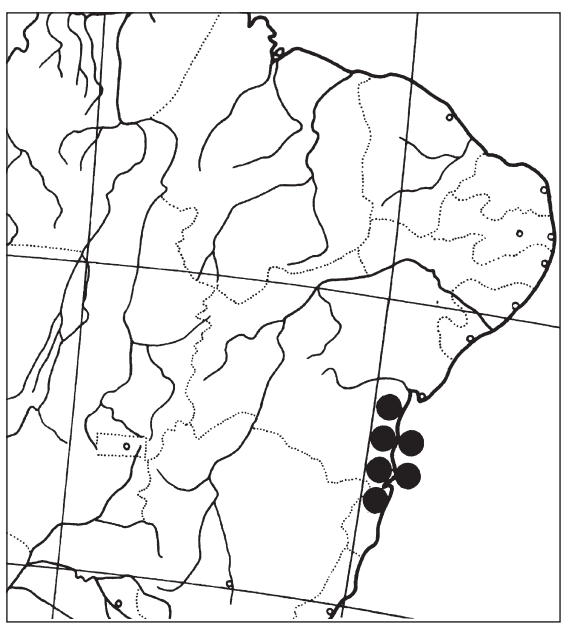

Map 4. Distribution of Pseudoxandra bahiensis Maas.

Tree 3-20 m tall, 8-25 cm diam.; young twigs glabrous. Leaves: petiole 3-10 $\mathrm{mm}$ long, 1-2 mm diam.; lamina narrowly oblong-elliptic, $10-20$ by $2.5-6 \mathrm{~cm}$ (leaf index $3.2-4.5$ ), coriaceous, rather densely to densely verruculose, shiny, dark brown to green above, brown to green below, glabrous or rarely with some scattered appressed hairs above, glabrous to sparsely covered with appressed hairs to $4 \mathrm{~mm}$ long below, particularly near base, primary vein, and margins, base obtuse, sometimes acute, with 2 angular to toothlike projections on either side, apex acuminate (acumen 5-15 mm long), secondary veins indistinct, straight, c. 15-25 (exact count difficult) on either side of primary vein, flat to slightly prominent above, angles with primary vein $75-85^{\circ}$, smallest distance of marginal vein from margin 1-3 mm. Inflorescences 1-3-flowered, or with (many) more flowers in succession in glomerules, produced from leafless branches; peduncles 1-2 $\mathrm{mm}$ long, fruiting peduncles to $5 \mathrm{~mm}$ long; bracts 3 or 4, depressed ovate, 1-2 mm long, outer side sparsely to rather densely covered with appressed hairs; pedicels 2-3 $\mathrm{mm}$ long, 1-2 mm diam., fruiting pedicels up to $9 \mathrm{~mm}$ long and $5 \mathrm{~mm}$ diam.; sepals depressed ovate, 2-4 by 4-6 $\mathrm{mm}$, outer side glabrous to rather densely covered with appressed hairs; petals green to greenish yellow, to cream in vivo, margins often ciliate, outer ones broadly ovate to broadly elliptic, 7-10 by $6-7 \mathrm{~mm}$, outer side glabrous, inner ones concave at the base, apical part slightly reflexed, broadly ovate, c. 12 by c. $10 \mathrm{~mm}$, outer side glabrous; stamens $2-2.3 \mathrm{~mm}$ long, connective appendage $0.7-1$ by $0.3-0.5 \mathrm{~mm}$; carpels glabrous. Monocarps $1-15$, wine-red to black when mature in vivo, black in sicco, globose to depressed globose, 15-18 mm diam., apex with a central or eccentric apicle (apicle 1-3 mm long), wall $1.2-1.8 \mathrm{~mm}$ thick, stipes $5-20$ by $2-3 \mathrm{~mm}$; fruiting receptacle depressed ovoid, $6-15$ by $6-10 \mathrm{~mm}$. Seeds transversely ellipsoid, 7-11 by $11-14 \mathrm{~mm}$, brown.

Distribution - The Brazilian state of Bahia.

Habitat \& Ecology - In primary forest ('mata higrófila Sul Baiana'). At low elevations around sea level, but a few collections from Serra Javi at up to $900 \mathrm{~m}$. Flowering: June to October; fruiting: throughout the year.

Vernacular names - Brazil: Pindaíba, Pindaíba preta. 


\section{Pseudoxandra borbensis Maas, spec. nov. - Fig. 6; Map 5}

Species pedunculis pro rata longis, foliis venis secundariis sub angulo angusto exeuntibus, lamina subtus pilis crispis obtecta distincta. - Typus: Henderson et al. 355 (holo INPA; iso F, GH, K, MO, NY, U, US), Brazil, Amazonas: Mun. Borba, BR 230 (Estrada Transamazonica), $5 \mathrm{~km}$ E of Sucunduri, 7 May 1985.

Tree $10 \mathrm{~m}$ tall, diameter unknown; young twigs rather densely covered with appressed, greyish hairs, soon glabrous. Leaves: petiole 5-6 mm long, c. $2 \mathrm{~mm}$ diam.; lamina narrowly oblong-elliptic, $20-30$ by $4-6 \mathrm{~cm}$ (leaf index $4.6-5$ ), coriaceous, rather densely verruculose, somewhat shiny, dark brown above, brown below, glabrous above, rather densely covered with appressed, greyish, curly hairs and some scattered needlelike hairs to $2 \mathrm{~mm}$ long below, base obtuse, with indistinct angular projections on either side, apex long-acuminate (acumen 10-20 mm long), secondary veins distinct, curved, 11-15 on either side of primary vein, prominent above, angles with primary vein $45-50^{\circ}$, smallest distance of marginal vein from margin $2-3 \mathrm{~mm}$. Inflorescences 1 - or 2- (or 3-)flowered, produced from leafless branches, only fruiting stages seen; fruiting peduncles $5-9 \mathrm{~mm}$ long; bracts to about 10 , very broadly ovate, $3-5 \mathrm{~mm}$ long, outer side densely covered with appressed, greyish hairs; fruiting pedicels $3-5 \mathrm{~mm}$ long, 2-3 mm diam.; sepal remnants with the outer side densely covered with appressed, greyish hairs; petals, stamens, and carpels not seen. Monocarps $8-15$, green in vivo, black in sicco, globose, $12-14 \mathrm{~mm}$ diam., apex minutely apiculate (apicle $<0.1 \mathrm{~mm}$ long), wall $<0.5 \mathrm{~mm}$ thick, stipes with a very rough surface, c. 6 by $2-3 \mathrm{~mm}$; fruiting receptacle globose to depressed ovoid, 5-8 $\mathrm{mm}$ diam. Seeds transversely ellipsoid, $9-11$ by $7-8 \mathrm{~mm}$, pale brown.

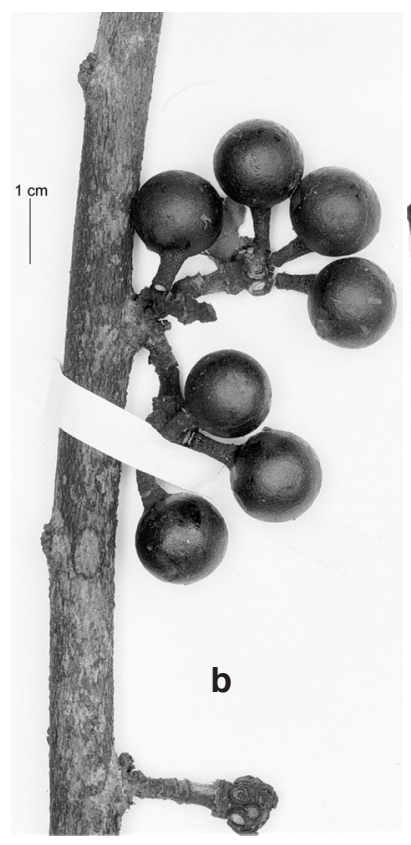

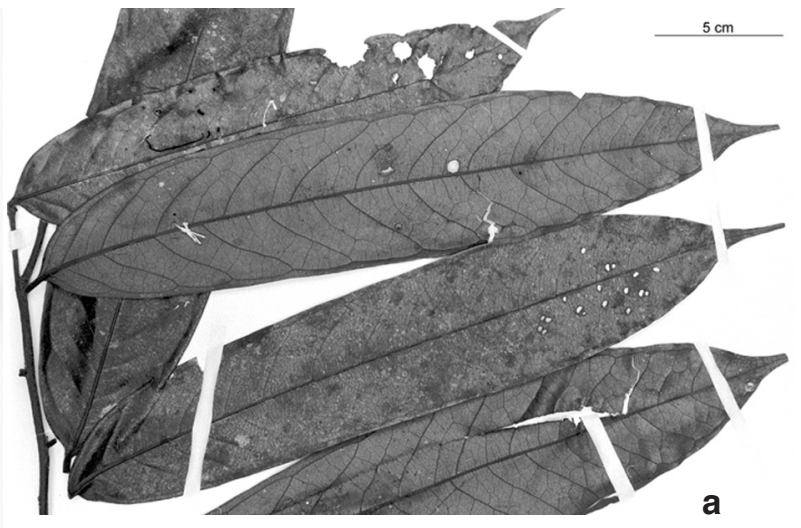

Fig. 6. Pseudoxandra borbensis Maas. Isotype specimen. a. Closer view of leaves; b. close-up view of monocarps (Henderson et al. 355, U). 


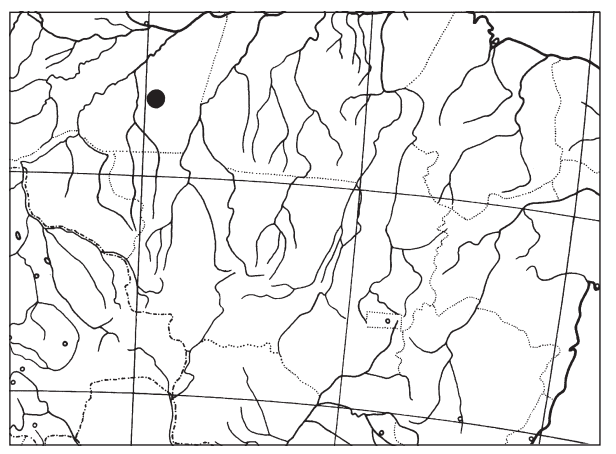

Map 5. Distribution of Pseudoxandra borbensis Maas.

Distribution - Amazonian Brazil (Mun. Borba).

Habitat \& Ecology - In non-inundated forest. Elevation unknown. Flowering time unknown; fruiting: May. Only known from the type collection.

Note - As far as can be judged from a single collection, $P$. borbensis is best recognized by the comparatively long peduncles, leaves with distinct secondary veins which form a narrow acute angle with the primary vein, and the curly hairs that are noticeable on the lower side of the leaves.

\section{Pseudoxandra cauliflora Maas, spec.nov. - Fig. 7; Map 6}

Species cauliflora, foliis oblongo-ellipticis petiolis brevibus distincta. - Typus: Daly et al. 4424 (holo U; iso NY), Brazil, Amazonas: São Paulo de Olivença, Estrada Bomfim, $6 \mathrm{~km} \mathrm{~S}$ of town centre, 23 Nov. 1986.

Treelet, 4-10 m tall, 3-5 cm diam.; young twigs glabrous. Leaves: petiole 2-3(-4) $\mathrm{mm}$ long, $1-1.5 \mathrm{~mm}$ diam.; lamina narrowly oblong-elliptic, $11-16$ by $4.5-6.5 \mathrm{~cm}$ (leaf index 2.3-3.1), chartaceous, densely verruculose, not shiny, greyish to brownish green above, pale brown below, glabrous above, glabrous below, base obtuse (angle c. $90^{\circ}$ ), with 2 vague, angular to toothlike projections on either side, apex abruptly acuminate (acumen 10-20 mm long), secondary veins indistinct, straight, 13-15 on either side of primary vein, slightly prominent above, angles with primary vein $75-80^{\circ}$, smallest distance of marginal vein from margin (1.5-)2-2.5 mm. Inflorescences $1-$ severalflowered, produced from the main trunk. Flowers not seen; fruiting peduncles c. 10 $\mathrm{mm}$ long, c. $3 \mathrm{~mm}$ diam.; fruiting pedicels $10-15 \mathrm{~mm}$ long, 1.5-2 mm diam.; bracts not seen; sepals depressed ovate, $2-3$ by c. $4 \mathrm{~mm}$, outer side glabrous; petals, stamens, and carpels not seen. Monocarps 5-10, green, maturing red to blue-black in vivo, black in sicco, subglobose, 15-17 mm diam., apex rounded or apiculate (apicle $<0.5$ $\mathrm{mm}$ long), wall $0.2-0.4 \mathrm{~mm}$ thick, stipes red, $12-20$ by $1-2 \mathrm{~mm}$; fruiting receptacle depressed globose to subglobose, 3-4 mm diam. Seeds globose, 13-14 mm diam., dark, shiny brown.

Distribution - W Amazonian Brazil, Amazonian Colombia, and Amazonian Peru.

Habitat \& Ecology - In non-inundated forest, on white sand covered with a layer of litter and humus 10-30 cm deep, or on lateritic to clayey soil. At low elevations up to $150 \mathrm{~m}$. Flowering time unknown; fruiting: September and November. 


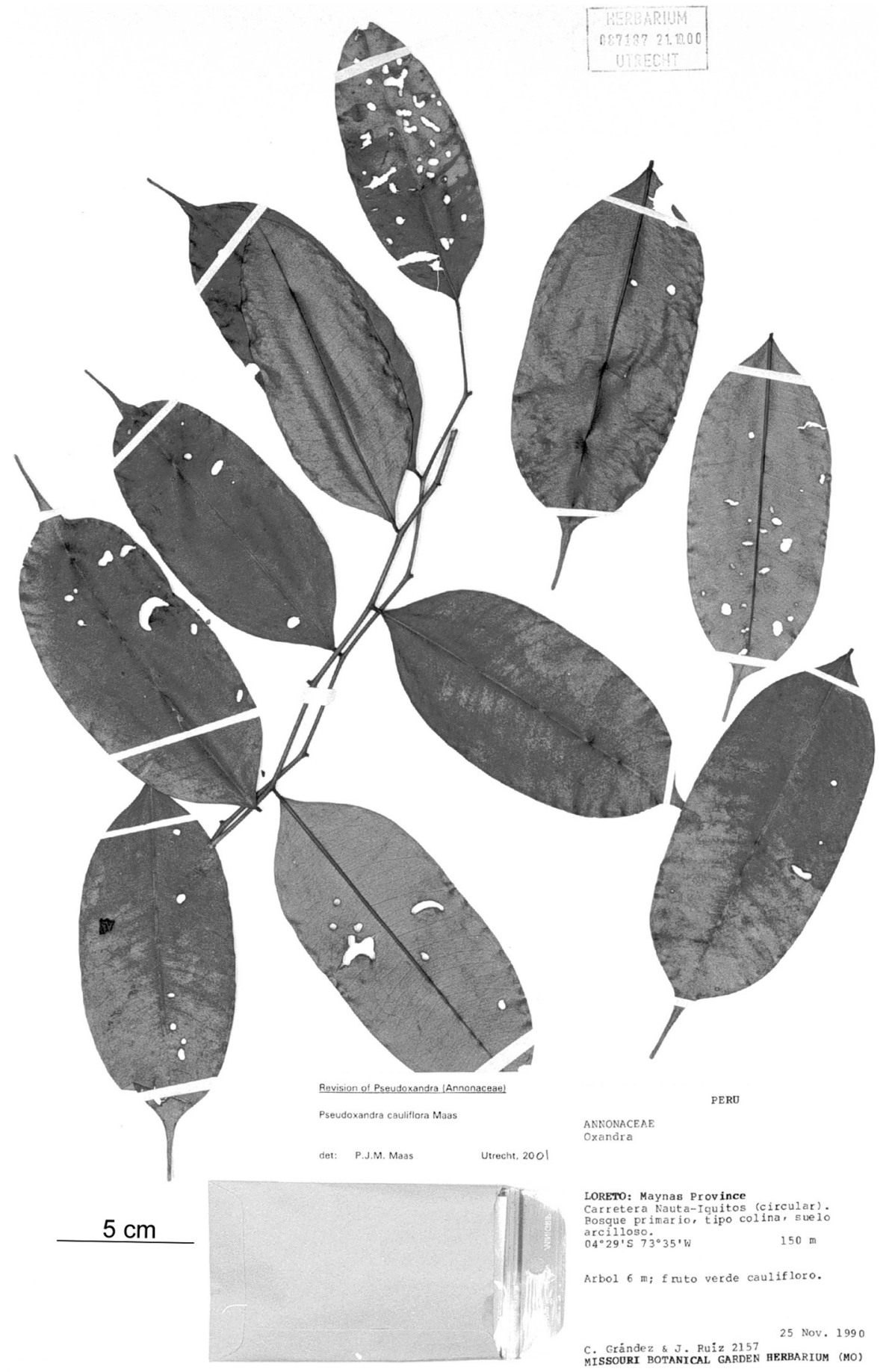

Fig. 7. Pseudoxandra cauliflora Maas (Grández \& Ruiz, 2157, U). 


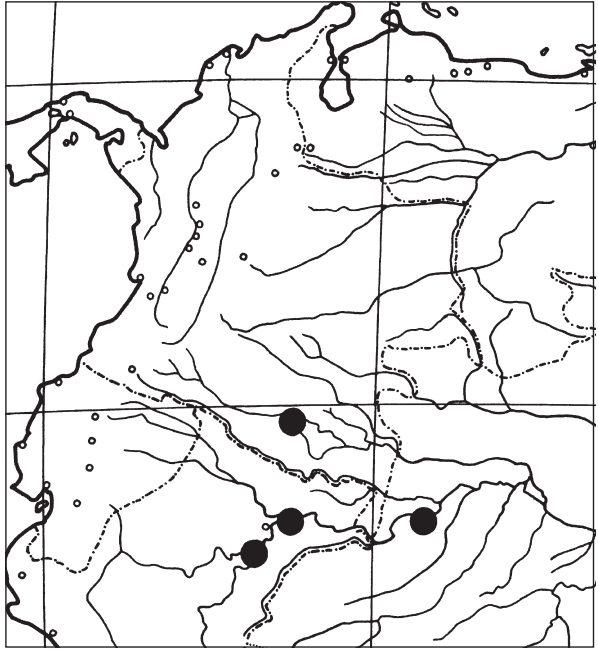

Map 6. Distribution of Pseudoxandra cauliflora Maas.

Note - Pseudoxandra cauliflora has some striking features: short petioles (mostly $\leq 3 \mathrm{~mm}$ long), an oblong-elliptic, more or less parallel-sided and relatively wide lamina abruptly terminating in a long tip, and with the primary vein sharply protruding below, and inflorescences produced from the main trunk (from which the epithet cauliflora has been derived). Good flowering material is necessary to complete the description.

Other specimens examined:

Colombia. Amazonas: Río Caquetá, 700 m below Isla Mariñame, Brand et al. 1504 (COAH).

PERU. Loreto: Prov. Maynas, Distr. Amazonas, Comunidad piloto Roca Eterna, 120-130 m, Grández \& Jaramillo 2796 (U); rd from Nauta to Iquitos, 150 m, Grández \& Ruiz 2157 (OWU, U).

BRAZIL. Amazonas: Campo Petrolifero de Urucu, estrada de acesso Porto Evandro-Coari, Cunha \& Raimundo 284 (HUAM).

\section{Pseudoxandra cuspidata Maas - Map 7}

Pseudoxandra cuspidata Maas, in Maas et al. (1986) 267, f. 12a-d, 14. - Type: Irwin, Pires \& Westra 47819 (holo U; iso F, K, MG, MICH, NY, UB, US, WU), French Guiana: Oyapock River, $1 \mathrm{~km} \mathrm{~N}$ of mouth of Rio Iaué, 25 Aug. 1960.

Tree 5-25 $\mathrm{m}$ tall, 5-20 cm diam.; young twigs glabrous, sometimes with a whitish bark. Leaves: petiole 2-6 $\mathrm{mm}$ long, $0.5-1 \mathrm{~mm}$ diam.; lamina narrowly elliptic to narrowly obovate, $8-13(-16)$ by $2-3.5(-5) \mathrm{cm}$ (leaf index $(2.8-) 3.1(-5.5)$ ), chartaceous, densely (to sometimes sparsely) minutely verruculose, sometimes slightly shiny, green to greyish green, sometimes brownish above, brown to green below, glabrous above, usually sparsely covered with appressed hairs to $2(-3) \mathrm{mm}$ long below, soon glabrous, base acute to obtuse, sometimes with 2 indistinct angular projections on either side, apex abruptly acuminate (acumen 10-20(-30) mm long, the tip itself obtuse), secondary veins indistinct, straight, $12-15(-17)$ on either side of primary vein, slightly prominent above, angles with primary vein $70-80^{\circ}$, smallest distance of marginal vein from margin $0.5-1 \mathrm{~mm}$. Inflorescences 1 -several-flowered, axillary or produced from older leafless branches; peduncles $1 \mathrm{~mm}$ long, fruiting peduncles $2-4 \mathrm{~mm}$ long; 


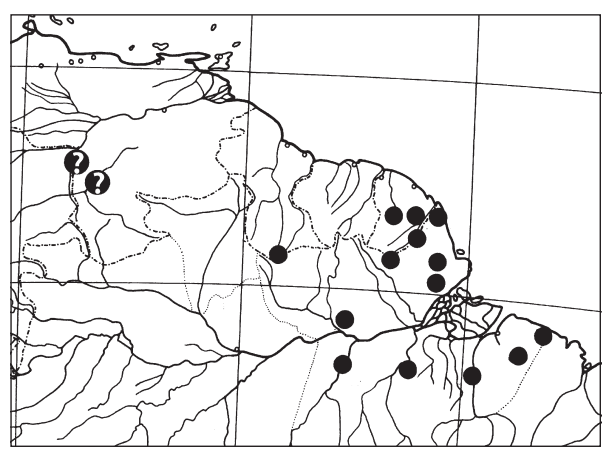

Map 7. Distribution of Pseudoxandra cuspidata Maas.

bracts 2-5, depressed ovate, 1-2 mm long, outer side rather densely covered with appressed hairs, margins ciliate; pedicels $1 \mathrm{~mm}$ long, $1 \mathrm{~mm}$ diam., fruiting pedicels 2-5 mm long, 2-4 mm diam.; sepals depressed ovate, 1-2 by 2-3 mm, outer side glabrous, margins ciliate; petals green in vivo, outer ones elliptic, $5-6$ by c. $4 \mathrm{~mm}$, outer side glabrous, margins sometimes ciliate, inner ones ovate, $5-7$ by c. $3 \mathrm{~mm}$, outer side glabrous; stamens $1.6-1.7 \mathrm{~mm}$ long, connective appendage $0.3-0.5 \mathrm{~mm}$; carpels glabrous. Monocarps 2-12, green, maturing yellow, orange, to red in vivo, black in sicco, globose to depressed globose, $9-16 \mathrm{~mm}$ diam., apex with a central or eccentric apicle (apicle $0.5-1 \mathrm{~mm}$ long), wall $0.3-0.8 \mathrm{~mm}$ thick, stipes $9-19$ by $1-2$ $\mathrm{mm}$; fruiting receptacle depressed ovoid, 3-5 mm diam. Seeds transversely ellipsoid to globose, $7-11$ by $8-11 \mathrm{~mm}$, brown.

Distribution - Guyana, French Guiana and adjacent Brazil (Amapá and Pará).

Habitat \& Ecology - In non-inundated forest, mostly on clayey soil. At elevations from sea level up to $450 \mathrm{~m}$. Flowering: May and October; fruiting: April, May, and from August to December.

Uses - Straight tree much used for hunting arrows (Rosa \& Santos 1788). Tree used for canoe poles and fishing rods (J.M. Pires et al. 50444). Leaves and bark used as a remedy against fever (French Guiana). Wood used for ceilings and firewood (Brazil).

Vernacular names - Brazil: Envira camuci, Envireira folha miuda, Lamuci. French Guiana: La moussé, Lamoussé, Malupete.

Notes - Pseudoxandra cuspidata is easily recognizable by its abruptly acuminate (= cuspidate) narrow leaves in combination with the often eccentric apicle of the monocarps. The young twigs often have a white, scurfy layer recalling that of Oxandra leucodermis.

Prévost \& Sabatier 2227 from French Guiana, collected in vegetative state, has leaves with a cusp to almost $30 \mathrm{~mm}$ long.

Two collections from the Venezuelan state of Amazonas (Fernández et al. 6155 (U) from Dep. Atures, base of Cerro Cuao, Caño Piedra, $75 \mathrm{~km} \mathrm{SE}$ of Puerto Ayacucho, 1050 m, and Sanoja et al. 2941 (NY, U) from Dep. Atures, Caño Piedra, 115 km SE of Puerto Ayacucho, $1500 \mathrm{~m}$ ) resemble this species in leaves and fruit. However, the primary vein is impressed instead of raised on the upper side. Both collections are of plants inhabiting granitic outcrops, where they appear to be frequent. Although they do not match with Pseudoxandra in one important character, they might yet, in our view, represent an undescribed species. They are marked on the distribution map with a ?. 


\section{Pseudoxandra duckei Maas, spec.nov. - Fig. 8, 9; Map 8}

Pseudoxandrae acreanae valde affinis, sed ab ea facile distinguibilis foliis brevioribus, ac vena marginali a margine pro ratione magis remota. - Typus: Albuquerque \& Paula 6716 (holo INPA, 2 sheets), Brazil, Amazonas: Estrada Manaus-Itacoatiara, km 26, Reserva Florestal Ducke, 26 April 1967.

Tree 5-7 m tall, diameter unknown; young twigs densely covered with appressed, pale whitish hairs to $3 \mathrm{~mm}$ long, soon glabrous. Leaves: petiole $3-5 \mathrm{~mm}$ long, c. $1 \mathrm{~mm}$ diam.; lamina narrowly elliptic, $9-16$ by $3-6 \mathrm{~cm}$ (leaf index $2.5-3$ ), chartaceous, not or sparsely verruculose, slightly shiny, dark brown to brownish green above, brown below, sparsely covered with appressed, whitish hairs above, soon glabrous, sparsely covered with appressed, white hairs to $3 \mathrm{~mm}$ long below, particularly along the veins, soon becoming subglabrous, base acute to obtuse, with 2 indistinct to distinct angular projections on either side close to the base, apex abruptly acuminate (acumen 5-15 mm long), secondary veins distinct, straight to slightly curved, 9-11(-13) on either side of primary vein, prominent above, angles with primary vein $50-65^{\circ}$, smallest distance of marginal vein from margin 3-6 mm. Inflorescences 1- or 2-flowered, produced from older leafless branches; peduncles 3-5 mm long, not or little elongating in fruit, fruiting peduncles $3-5 \mathrm{~mm}$ diam.; bracts 4 or 5 , very broadly ovate, $7-10 \mathrm{~mm}$ long, outer side densely covered with appressed, silky white hairs; pedicels very short, hidden by the large bracts during flowering, fruiting pedicels about $1 \mathrm{~mm}$ long, to $5 \mathrm{~mm}$ diam.; sepals very broadly ovate, $6-10$ by $6-10 \mathrm{~mm}$, outer side densely covered with appressed, silky white hairs; petals only seen in bud, outer side densely covered with appressed, silky white hairs; stamens not seen; carpels glabrous. Monocarps 10-30, black when ripe in vivo, dark brown in sicco, globose to subglobose, 11-13 mm diam., apex rounded or minutely apiculate (apicle $<0.1 \mathrm{~mm}$ long), wall c. $0.5 \mathrm{~mm}$ thick, stipes $10-15$ by $2 \mathrm{~mm}$; fruiting receptacle depressed ovoid to subglobose, 5-9 $\mathrm{mm}$ diam. Seeds transversely ellipsoid, $12-13$ by $7-8 \mathrm{~mm}$, shiny brown.

Distribution - C Amazonian Brazil, the Reserva Ducke.

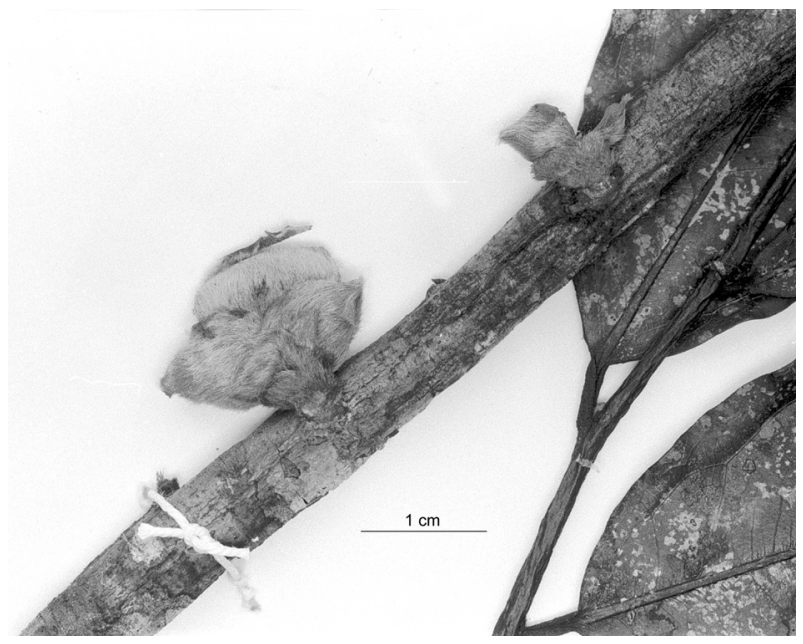

Fig. 8. Pseudoxandra duckei Maas. Close-up view of flower of holotype (Albuquerque \& Paula 67-16, INPA). 


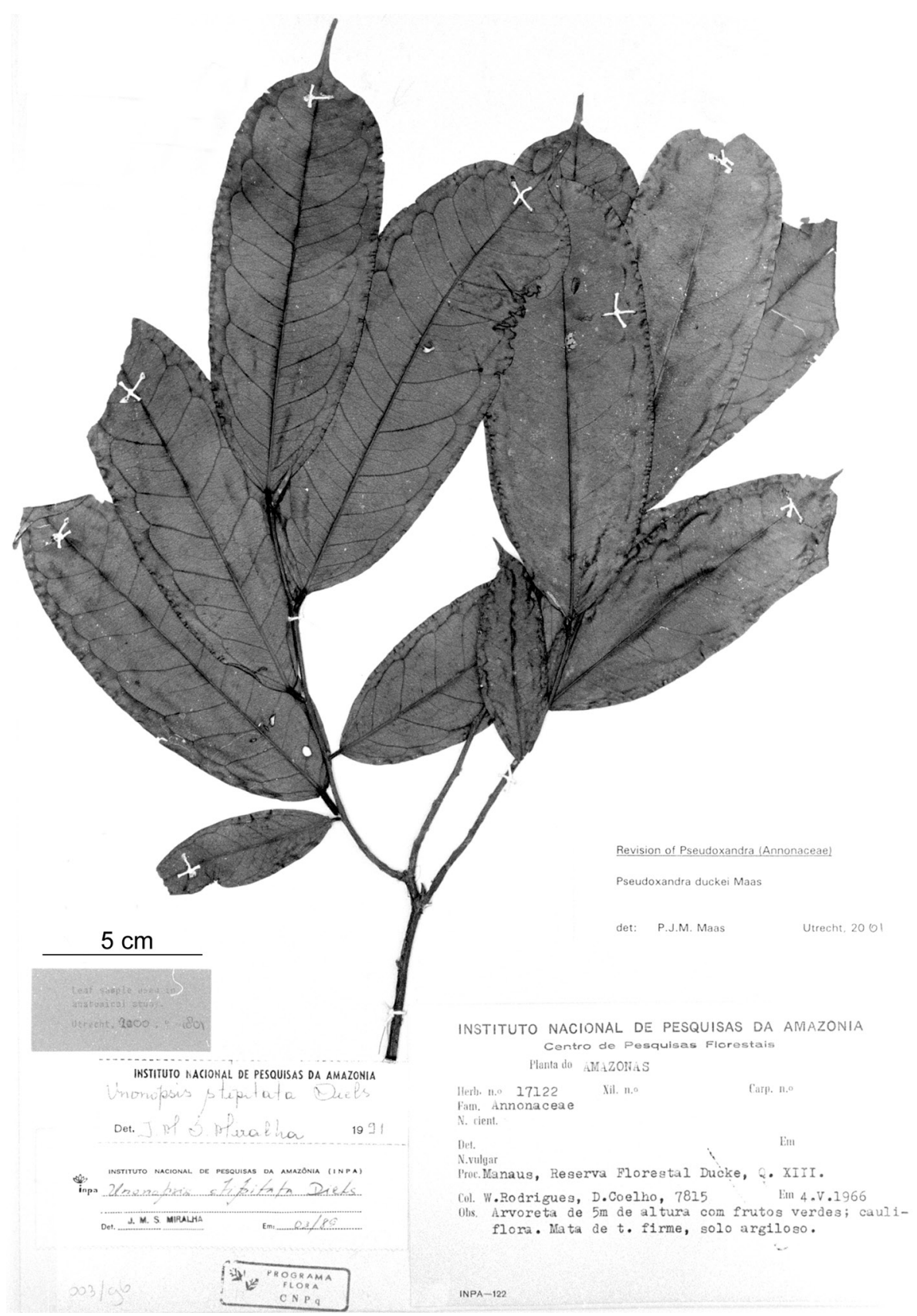

Fig. 9. Pseudoxandra duckei Maas (Rodrigues \& Coêlho 7815, INPA). 


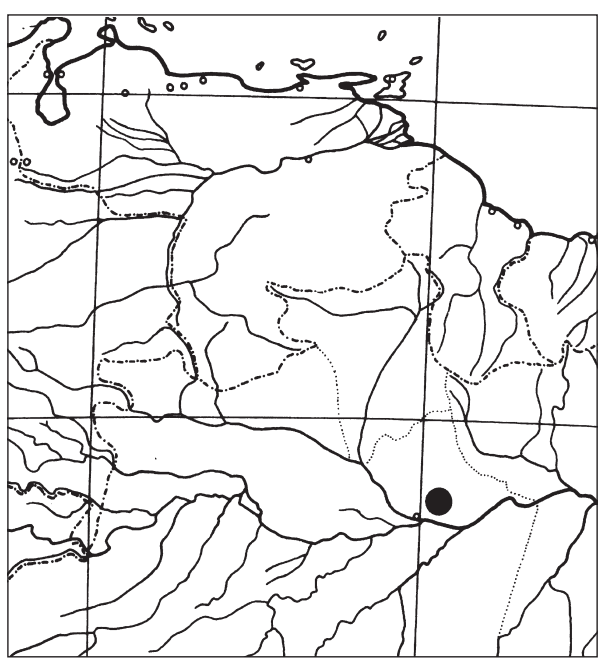

Map 8. Distribution of Pseudoxandra duckei Maas.

Habitat \& Ecology - In non-inundated forest, on clayey or sandy soil. At low elevations. Flowering: April and May; fruiting: January, April, and May.

Note - Pseudoxandra duckei is very close to P.acreana and P. williamsii. The three species all have the marginal vein quite far removed from the margin, relatively large sepals, and a dense indument of appressed hairs on almost all flower parts. The present species is different, however, in its smaller leaves, which lack the curly hairs, and in the marginal vein which, in comparison, is even further removed from the leaf margin. In Flora da Reserva Ducke this species is mentioned as $P$. aff. williamsii (Ribeiro et al. 1999: 129).

Selection of other specimens (5) examined:

BRAZIL. Amazonas: Reserva Florestal Ducke, Sabía 2, Costa et al. 690 (INPA); Reserva Florestal Ducke, Quadra 8, W.A. Rodrigues \& Monteiro 5661 (INPA); Reserva Florestal Ducke, Quadra 13, W.A. Rodrigues \& D. Coêlho 7815 (INPA).

\section{Pseudoxandra leiophylla (Diels) R.E. Fr. - Map 9}

Pseudoxandra leiophylla (Diels) R.E. Fr. (1937) 226. - Unonopsis leiophylla Diels (1931) 80. - Type: Spruce 2473 (holo B; iso C, E, G, GH, K, LE, NY, S, W), Brazil, Amazonas: Rio Vaupés ('Rio Vaupés, gapó [= igapó]'), Sept. 1852.

Pseudoxandra coriacea R.E. Fr. (1937) 226, syn. nov. - Type: Spruce 3353 (holo B; iso BR, E, F, G, GH, K, LE, NY, OXF, P, S, W), Venezuela, Amazonas: Río Pasimoni ('Ad flumina Casiquari, Vasiva et Pacimoni'), Febr. 1854.

Tree 4-25 m tall, 10-45 cm diam.; young twigs densely covered with appressed hairs, very soon glabrous. Leaves: petiole 2-8 mm long, 1-2 mm diam.; lamina narrowly elliptic, narrowly oblong-elliptic, or narrowly obovate, 10-20 by 4-7 cm (leaf index 2.5-3.8), coriaceous, densely to rather densely verruculose, rarely smooth, strongly shiny, dark brown, greenish brown, or blackish brown above, brown to dark brown below, glabrous above (only covered with appressed hairs in the youngest stages), glabrous or sparsely covered with appressed hairs to $2 \mathrm{~mm}$ long below, base acute to obtuse, 
without or with indistinct angular projections on either side, apex acute to acuminate (acumen 5-15 mm long), secondary veins mostly indistinct, straight to curved, 10-15 on either side of primary vein, slightly prominent to flat above, angles with primary vein $60-80^{\circ}$, smallest distance of marginal vein from margin 1-2 mm. Inflorescences 1- or 2-flowered, axillary or produced from leafless branches; peduncles 1-2 mm long, fruiting peduncles $3-5 \mathrm{~mm}$ long; bracts $3-5$, depressed ovate, 1-2 mm long, outer side densely covered with appressed hairs, finally becoming glabrous; pedicels $1-5 \mathrm{~mm}$ long, 1-2 mm diam., fruiting pedicels 4-8 mm long, 3-4 mm diam.; sepals depressed ovate, $2-5$ by $4-7 \mathrm{~mm}$, outer side densely covered with appressed hairs, finally becoming glabrous; petals creamy white in vivo, outer ones concave, broadly ovate-triangular to ovate, $7-12$ by $7-8 \mathrm{~mm}$, outer side rather densely to densely covered with appressed hairs, inner ones strongly concave, broadly ovate, $5-7$ by $4-5 \mathrm{~mm}$ (7-9 by $4-5 \mathrm{~mm}$ when spread out), outer side glabrous except for a densely hairy zone from top to the base; stamens $1.5-3 \mathrm{~mm}$ long, connective appendage $0.5-1$ by $0.3-0.5 \mathrm{~mm}$; carpels subglabrous. Monocarps 2-15, green, maturing yellow, brown, red, to black in vivo, black to brown in sicco, globose, 9-14 mm diam., apex apiculate (apicle 0.5-1 mm long), wall $0.2-0.5 \mathrm{~mm}$ thick, stipes $1-5$ by $1-2 \mathrm{~mm}$; fruiting receptacle depressed ovoid to subglobose, 3-6 $\mathrm{mm}$ diam. Seeds transversely ellipsoid, 4-9 by 7-9 $\mathrm{mm}$, shiny brown.

Distribution - Amazonian Colombia, Venezuela, and adjacent Brazil.

Habitat \& Ecology - In periodically inundated igapó forest, on clayey to sandy soil. At elevations from sea level up to $420 \mathrm{~m}$. Flowering: June to September; fruiting: October to June.

Vernacular names - Colombia: Cargero. Venezuela: Karuari.

Collector's note - The fresh fruit smells like nutmegs (Spruce 3353).

Notes - Pseudoxandra leiophylla is recognized by its strongly shiny leaves, hairy petals, and shortly stipitate monocarps, the latter giving the fruit a glomerulate appearance. It is probably closest to $P$. lucida. The quantity of tiny warts in the leaves of this species is very variable. In most gatherings (including the type of P. coriacea) the leaves are densely verruculose, but in most Colombian material and also in the type of P. leiophylla the leaves appear to be almost destitute of warts (hence the epithet). A characteristic feature of this species is the articulation between stipe and monocarp body located in the widened apical part of the stipe, leaving a disk-like scar after the monocarp has dropped.

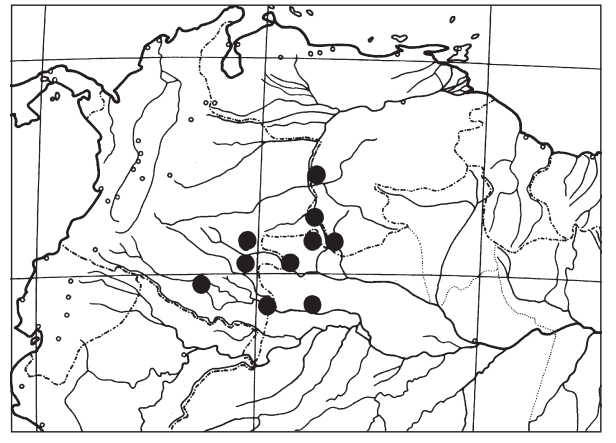

Map 9. Distribution of Pseudoxandra leiophylla (Diels) R.E. Fr. 
The collection J.M. Pires \& Silva 7926 (IAN) from Taraquá, Rio Vaupés, Amazonas, Brazil is aberrant in having somewhat larger leaves (up to 30 by $7 \mathrm{~cm}$ ) and hairy monocarps.

\section{Pseudoxandra longipes Maas, spec. nov. - Fig. 10; Map 10}

Species monocarpiis longestipitatis, foliis lucentibus venis secundariis pro ratione paucis distincta. - Typus: Monsalve B. 1073 (holo MO; iso CUVC, F, U), Colombia, El Valle: Bajo Calima, Concesión Pulpapel/Buenaventura, 100 m, 23 Aug. 1986.

Tree 6-15 m tall, c. $20 \mathrm{~cm}$ diam.; young twigs densely covered with appressed, brown hairs, very soon glabrous. Leaves: petiole 5-8 mm long, c. $1 \mathrm{~mm}$ diam.; lamina narrowly elliptic, $9-15$ by $2.5-5 \mathrm{~cm}$ (leaf index $2.6-4.8$ ), coriaceous, usually densely verruculose along midvein to sparsely verruculose elsewhere above, mostly sparsely verruculose below, mainly along primary vein, strongly shiny, green to dark green above, brownish below, glabrous above, glabrous below, except for some scattered appressed hairs to $2 \mathrm{~mm}$ long mainly along primary vein, base acute to obtuse, without angular projections, apex abruptly and distinctly acuminate (acumen 5-15 mm long), secondary veins indistinct, straight, $8-12(-15)$ on either side of primary vein, slightly prominent above, angles with primary vein $65-70^{\circ}$, smallest distance of marginal vein from margin 2-4 mm. Inflorescences 1-flowered, only seen in very young bud or mostly in fruiting stage, axillary or on leafless branches; fruiting peduncles 3-5 mm long, as thick as pedicels; bracts 2-5, depressed ovate, c. $1 \mathrm{~mm}$ long, outer side glabrous, margins ciliate; fruiting pedicels $4-7 \mathrm{~mm}$ long, 2-5 mm diam.; sepals depressed ovate-triangular, c. 1.5 by $2.5-3 \mathrm{~mm}$, outer side glabrous, margins ciliate; petals, stamens, and carpels not seen. Fruits solitary, produced from leafless branches or axillary. Monocarps 8-20, green in vivo, black in sicco, depressed globose to globose, 10-15 mm high, $12-15 \mathrm{~mm}$ diam., apex apiculate (apicle $<0.5 \mathrm{~mm}$ long), wall c. 0.5 $\mathrm{mm}$ thick, stipes (10-)20-30 by $1.5-2 \mathrm{~mm}$; fruiting receptacle depressed ovoid, 5-7 $\mathrm{mm}$ diam. Seeds transversely ellipsoid, c. 7 by $9-11 \mathrm{~mm}$, brown.

Distribution - The Pacific coast of Colombia (El Valle).

Habitat \& Ecology - In non-inundated forests ('bosque tropical pluvial'). At elevations up to 100 m. Flowering time unknown; fruiting: February, March, May, August, and September.

Vernacular names - Colombia: Cuangare, Guanabano.

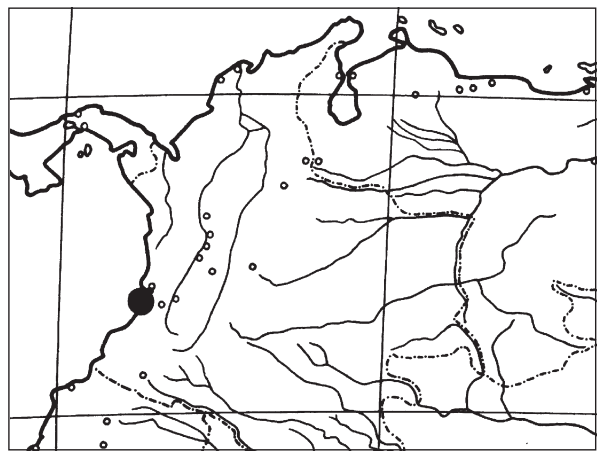

Map 10. Distribution of Pseudoxandra longipes Maas. 


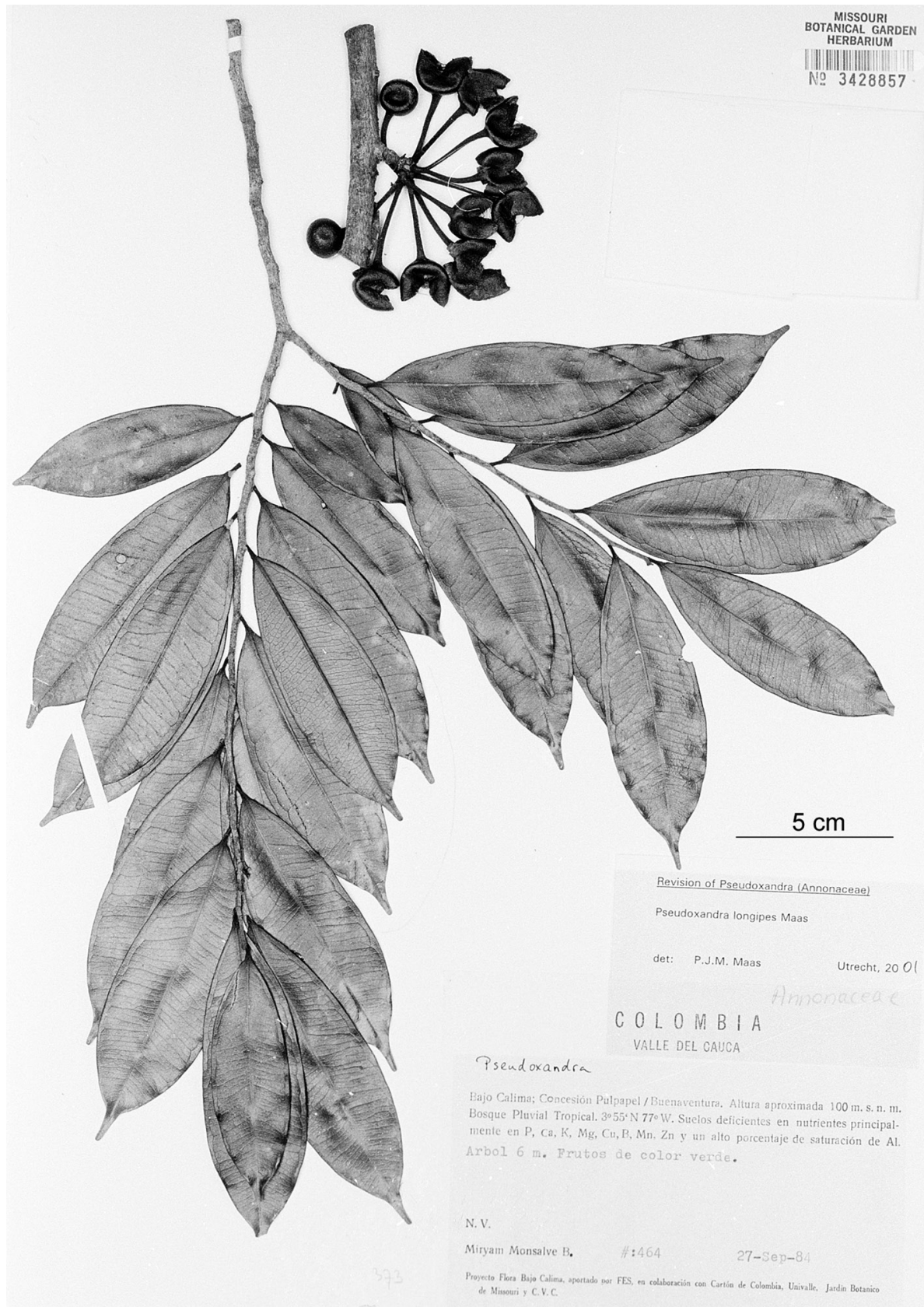

Fig. 10. Pseudoxandra longipes Maas (Monsalve B. 464, MO). 
Note - Some striking features of P. longipes are the long-stipitate monocarps, shiny leaves with a sharply prominent primary vein on the lower side, a fairly low number of secondary veins (mostly not exceeding 12), and a great concentration of tiny warts along the primary vein on the upper side. The relationship of this species is not yet clear and requires additional study.

Selection of other specimens (13) examined:

Colombia. El Valle: Río Calima, La Trojita, 5-50 m, Cuatrecasas 16399 (F, S); Corr. Canalete, km 28 vía Málaga, 50 m, Devía A. 3242 (U); Bajo Calima Concession, 16 km NW of Buenaventura, 50 m, Faber-Langendoen \& Rentería A. 501 (CUVC, U), Bajo Calima, Concesión Pulpapel/ Buenaventura, $100 \mathrm{~m}$, Monsalve B. 303 (MO, U).

\section{Pseudoxandra lucida R.E. Fr. - Fig. 2a, b; Map 11}

Pseudoxandra lucida R.E. Fr. (1937) 230, f. 3a-e. - Type: Kuhlmann $463=$ RB24264 (holo S; iso MO, RB), Brazil, Mato Grosso: Rio Ouro Preto, affluent of Rio Pacanova, 17 Sept. 1923.

Pseudoxandra guianensis (R.E. Fr.) R.E. Fr. (1937) 228, f. 1a-i, 2a, syn. nov. - Cremastosperma guianense R.E. Fr. (1934) 205. - Type: Forest Dep. Brit. Guiana 2093 = Davis 102 (holo K), Guyana, Apoteri, Rupununi River, 21 July 1931.

Malmea cuspidata Diels (1931) 78, syn. nov. - Type: Ll. Williams 113 (holo F; iso B, S), Peru, Loreto: Río Itaya, S of Hacienda Río Masána, 6 May 1929.

Tree (1-)3-20 m tall, to $30 \mathrm{~cm}$ diam.; young twigs subglabrous. Leaves: petiole 5-8 mm long, 1-2 mm diam.; lamina narrowly elliptic, narrowly oblong-elliptic, to narrowly obovate, $7-20$ by $2-6.5 \mathrm{~cm}$ (leaf index $2.6-5.1$ ), coriaceous, densely to rather densely verruculose, shiny, greyish green, green, greyish brown to dark brown above, often brown below, glabrous above, glabrous below or rarely covered with some appressed hairs to $1.5 \mathrm{~mm}$ long mainly near primary vein, base acute to sometimes obtuse, sometimes with 2 very weak angular projections on either side, apex acuminate (acumen $5-15(-20) \mathrm{mm}$ long), secondary veins indistinct, straight, 8-15(-18) on either side of primary vein, flat to slightly prominent above, angles with primary vein $60-80^{\circ}$,

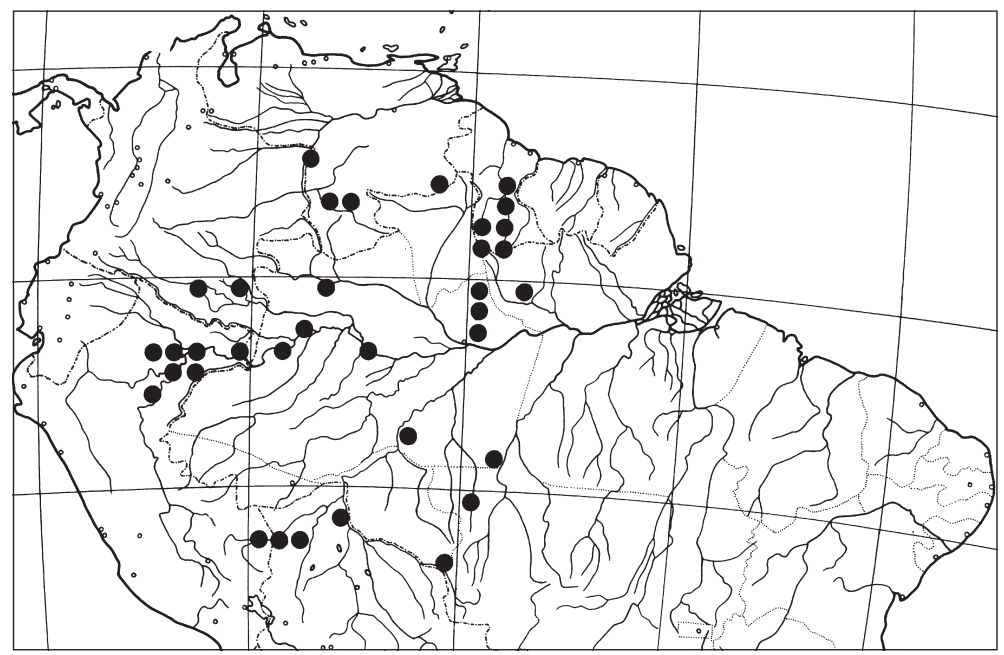

Map 11. Distribution of Pseudoxandra lucida R.E. Fr. 
smallest distance of marginal vein from margin 1-2 mm. Inflorescences 1- or 2- (or 3 -)flowered, axillary or produced from leafless branches, occasionally found at the base of a lateral shoot; peduncles 1-2 mm long, fruiting peduncles (1-)2-4(-5) mm long; bracts 2-4, depressed ovate, 1-2 mm long, outer side densely to rather densely covered with appressed hairs; pedicels $2-5 \mathrm{~mm}$ long, $1-1.5 \mathrm{~mm}$ diam., fruiting pedicels 3-8 $\mathrm{mm}$ long, $2-4 \mathrm{~mm}$ diam.; sepals depressed ovate, $1.5-3$ by $3-5 \mathrm{~mm}$, outer side rather densely to densely covered with appressed hairs; petals greenish cream, cream, to yellow in vivo, outer ones broadly ovate to ovate, $8-11$ by $6-10 \mathrm{~mm}$, outer side densely to rather densely covered with appressed hairs, inner ones concave, narrowly obovate to narrowly elliptic, $7-14$ by $5-7 \mathrm{~mm}$, outer side glabrous except for a hairy line running from base to apex; stamens 2-3.5 mm long, connective appendage to c. 1 by $0.5 \mathrm{~mm}$; carpels subglabrous. Monocarps $2-20(-30)$, green, maturing red, orange, dark purple to black in vivo, brown in sicco when young, black when mature, globose to sometimes ellipsoid, 9-14(-20) mm diam., apex rounded or apiculate (apicule $<1$ $\mathrm{mm}$ long), wall $0.2-0.5[-1.2] \mathrm{mm}$ thick, stipes $4-10$ by $1-2 \mathrm{~mm}$; fruiting receptacle subglobose to depressed ovoid, 3-7 $\mathrm{mm}$ diam. Seeds transversely ellipsoid to subglobose, $8-12$ by $9-11 \mathrm{~mm}$, brown.

Distribution - Throughout the Amazon Region of Brazil and bordering Andean countries and in Guyana.

Habitat \& Ecology - In periodically inundated forest (mainly in tahuampa and igapó), on clayey or sandy soil. Mostly at low elevations up to $250 \mathrm{~m}$, but in Venezuela up to $830 \mathrm{~m}$. Flowering and fruiting: throughout the year.

Vernacular names - Bolivia: Piraquina. Brazil: Envira amarela, Envira margosa, Envira preta. Colombia: Doojeco. Peru: Espintana, Siririca, Vara, Yutu banco. Venezuela: Yadayada.

Notes - For a long time we have regarded P.guianensis as a distinct species because of its somewhat smaller leaves and fruit. After coming across various intermediate forms however, we found it no longer justified to keep this species separate from the highly variable $P$. lucida.

Three gatherings from the Brazilian state of Rondônia, Mun. Porto Velho, near Usina Hidrelétrica de Samuel are aberrant in having quite small and shortly stipitate monocarps; all three collections originate from campinarana vegetation: Cid et al. 7423 (U); Dionizia et al. 30 (NY, US); Thomas et al. 5087 (K, NY, U, US). We are not yet sure whether this material falls within the concept of $P$. lucida or that it should merit varietal or even specific rank.

Several other slightly aberrant collections are worth noting. Maas et al. 8215, Pipoly et al. 12942, and Peters 36, from Peru and Colombia, are all characterized by quite large and ellipsoid (instead of globose) monocarps, and provided with long stipes (monocarps $20-25$ by $15-20 \mathrm{~mm}$, stipes $10-15 \mathrm{~mm}$ long).

Grández et al. 5238 (U) from Peru, Loreto, Puerto Almendras, matches this species fairly well except that it completely lacks warts on the leaves.

\section{Pseudoxandra obscurinervis Maas, spec. nov. - Fig. 11; Map 12}

Species foliis densissime verruculosis venis secundariis haud visibilibus distincta. - Typus: Prance et al. 11468 (holo INPA; iso K, MO, NY, S, U, US), Brazil, Amazonas: ManausIgarapé Leão Road, 5 km from Manaus-Caracaraí Road, 26 June 1971. 


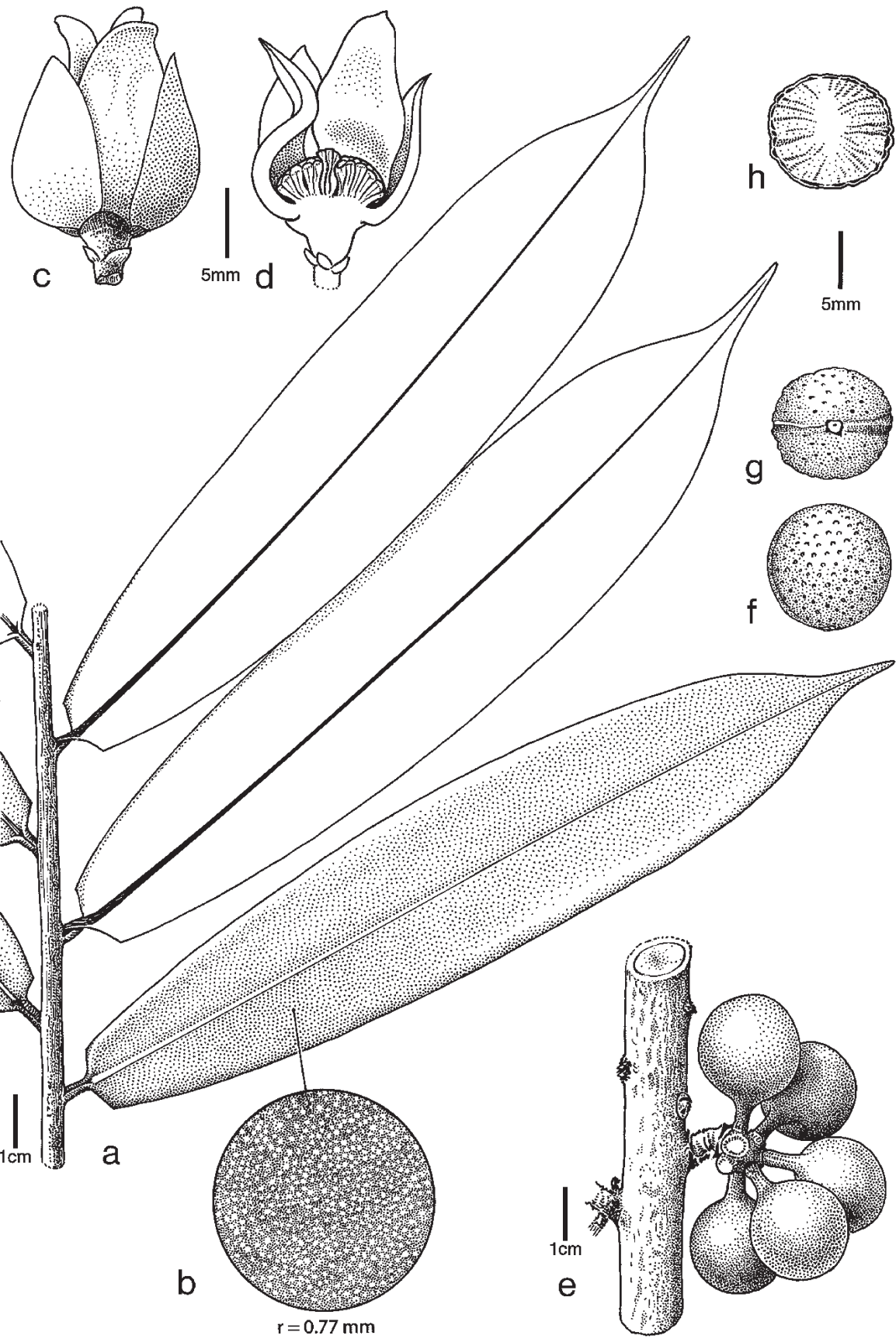

Fig. 11. Pseudoxandra obscurinervis Maas. a. Leafy branch; b. leaf surface enlarged showing tiny warts (verruculose); c. flower; d. dissected flower showing outer and inner petals, stamens, and carpels; e. fruiting branch; f. seed in equatorial view; g. seed in polar view; h. seed in transverse section (a, b, f-h: Prance et al. 11468; c, d: Webber s.n.; e: Souza et al. 302). 
Tree 6-25 m tall, 8-22 cm diam.; young twigs glabrous. Leaves: petiole 3-7 mm long, 1-2 mm diam.; lamina narrowly oblong-elliptic to narrowly oblong-obovate, $10-16$ by 2-4 cm (leaf index 3.2-7), coriaceous, very densely verruculose, shiny, dark blackish brown, sometimes slightly greenish tinged above, brown below, glabrous above, rarely with some scattered appressed hairs, sparsely covered with appressed hairs to $2 \mathrm{~mm}$ long below, soon glabrous, base obtuse, with 2 distinct, angular to toothlike projections on either side, apex acute to acuminate (acumen 10-15 mm long), secondary veins indistinct to practically invisible, 15-20 on either side of primary vein, straight, flat to slightly impressed above, angles with primary vein $65-70^{\circ}$, smallest distance of marginal vein from margin 1-1.5 mm. Inflorescences $1-5$-flowered, produced from older, leafless branches; peduncles $1 \mathrm{~mm}$ long, fruiting peduncles to 2-4 $\mathrm{mm}$ long; bracts 2-6, depressed ovate, 1-3 mm long, outer side sparsely covered with appressed hairs to glabrous; pedicels $1 \mathrm{~mm}$ long, $1-1.5 \mathrm{~mm}$ diam., fruiting pedicels $2-4 \mathrm{~mm}$ long, 3-5 mm diam.; sepals depressed ovate, c. 2 by $3-5 \mathrm{~mm}$, outer side glabrous; petals cream to yellow with pinkish to reddish inner base in vivo, outer ones broadly ovate to ovate, $8-12$ by $5-11 \mathrm{~mm}$, outer side glabrous, margins ciliate when young, inner ones ovate, basal part concave, apical part strongly reflexed, 11-15 by 5-10 mm, outer side glabrous; stamens $1.5-2.5 \mathrm{~mm}$ long, connective appendage flat $0.6-0.8$ by 0.1 $\mathrm{mm}$; carpels glabrous. Monocarps 2-10, green, maturing yellow, orange, red to black in vivo, the unripe ones brown and the ripe ones black in sicco, globose, 10-18 mm diam., apex apiculate (apicle $<0.5 \mathrm{~mm}$ long), wall $1-1.5 \mathrm{~mm}$ thick, stipes $2-7$ by $1-3$ $\mathrm{mm}$; fruiting receptacle depressed ovoid, 6-7 $\mathrm{mm}$ diam. Seeds transversely ellipsoid to globose, 8-10 mm high and about same diam., dark brown.

Distribution - Amazonian Brazil.

Habitat \& Ecology - In non-inundated forest, mostly on clayey soil. At low elevations up to $125 \mathrm{~m}$. Flowering: January, April, and June; fruiting: May to January, ripe fruits produced between September and January.

Vernacular name - Brazil: Envira preta.

Notes - Pseudoxandra obscurinervis is distinctive because of its densely verruculose lamina with almost invisible veins. It resembles $P$. bahiensis, but is separable from that species by an indistinct leaf venation and often narrower leaves. In Flora da Reserva Ducke this species is mentioned as $P$. coriacea (Ribeiro et al., 1999).

At first sight $P$. obscurinervis might be confused with Oxandra xylopioides, a common Amazonian species. The latter is clearly distinct, though, by the midvein which is impressed (and not raised) above. Moreover, O. xylopioides lacks a marginal vein.

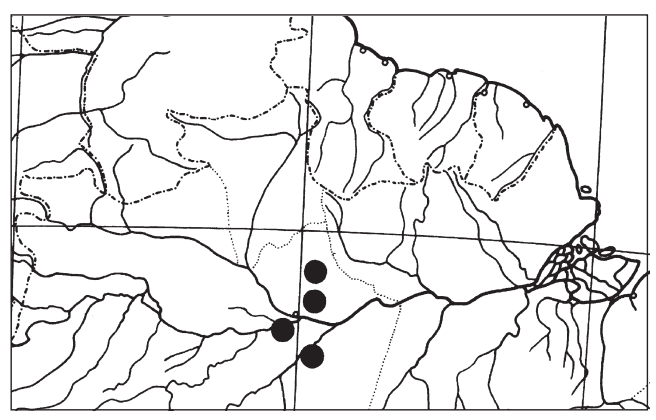

Map 12. Distribution of Pseudoxandra obscurinervis Maas. 
Selection of other specimens (27) examined:

BRAZIL. Amazonas: Reserva Florestal Ducke, km 26 of Hwy. Manaus-Itacoatiara, Assunção 425 (U); Distr. Agropecuário, c. 90 km N of Manaus, Reserva 1501, 50-125 m, Boom et al. 8636 (K, NY, RB, U); km 63 of Hwy. Manaus-Caracaraí, Cid et al. 30 (MO, NY, U, US); Mun. Borba, Rio Madeira, road from Borba to Rio Mapurí, Cid et al. 3921 (NY, U); Mun. Borba, Igarapé das Onças, 3 km N of Vila de Canumã, Rio Canumã, Cid et al. 3962 (F, K, MO, NY, U); Mun. Presidente Figueiredo, 'Estrada do Canteiro' of 'Usina Hidreléctrica de Balbina', Cid et al. 7576 (MO, NY, U); Distr. Agropecuário, c. 90 km N of Manaus, Fazenda Porto Alegre, Reserva 3209, Lopes s.n. (U); Manaus, Webber s.n. (HUAM, U).

\section{Pseudoxandra pacifica Maas - Map 13}

Pseudoxandra pacifica Maas, in Maas et al. (1986) 270, f. 15. - Type: Forero et al. 1347 (holo COL, 2 sheets; iso MO), Colombia, Chocó: Río Serrano, affluent of Río Atrato, 4-6 km above Guayabal, 50 m, 29 April 1975.

Tree 2.5-20 m tall, 10-30 cm diam.; young twigs subglabrous. Leaves: petiole 3-7 mm long, $2-3 \mathrm{~mm}$ diam.; lamina narrowly oblong-elliptic, $17-27$ by $6-8.5 \mathrm{~cm}$ (leaf index 2.6-3.5), coriaceous, densely to rather densely verruculose, somewhat shiny, greyish green to greenish brown above, grey to brown below, glabrous below except for some very scarce appressed hairs along primary vein, base obtuse, with 2 angular to toothlike projections on either side, or those indistinct to lacking, apex acute to long-acuminate (acumen 10-20 mm long), secondary veins indistinct, straight, 16-19 on either side of primary vein, slightly prominent to flat above, angles with primary vein $75-90^{\circ}$, smallest distance of marginal vein from margin 2-5 $\mathrm{mm}$. Inflorescences 1-flowered, axillary or produced from leafless branches; peduncles $2 \mathrm{~mm}$ long, fruiting peduncles 3-5 mm long; bracts 2 or 3, depressed ovate, 1-2 mm long, outer side rather densely covered with appressed hairs, margins ciliate; pedicels c. $2 \mathrm{~mm}$ long, c. $2 \mathrm{~mm}$ diam., fruiting pedicels 7-10 $\mathrm{mm}$ long, $3 \mathrm{~mm}$ diam.; sepals depressed ovate-triangular, 2-4 by $4-5 \mathrm{~mm}$, outer side glabrous; petals yellow to cream in vivo, outer ones broadly ovate, $10-12$ by $7-8 \mathrm{~mm}$, outer side glabrous, inner ones narrowly ovate, basal part somewhat concave, apical part erect or slightly reflexed, c. 10 by c. $6 \mathrm{~mm}$, outer side glabrous; stamens $2.2-2.5 \mathrm{~mm}$ long, connective appendage $0.8-0.9$ by $0.1-0.2 \mathrm{~mm}$; carpels glabrous. Monocarps 3-11, green to orange, red, or black in vivo, brown in sicco, transversely broadly ellipsoid to subglobose, slightly asymmetric, $15-21 \mathrm{~mm}$ diam., apex rounded to minutely apiculate (apicle $<0.5 \mathrm{~mm}$ long), wall $0.4-0.8 \mathrm{~mm}$ thick, stipes $11-24$ by 2-2.5 mm; fruiting receptacle depressed ovoid, 5-6 mm diam. Seeds transversely ellipsoid to globose, $8-11$ by $10-13 \mathrm{~mm}$, brown to dark brown.

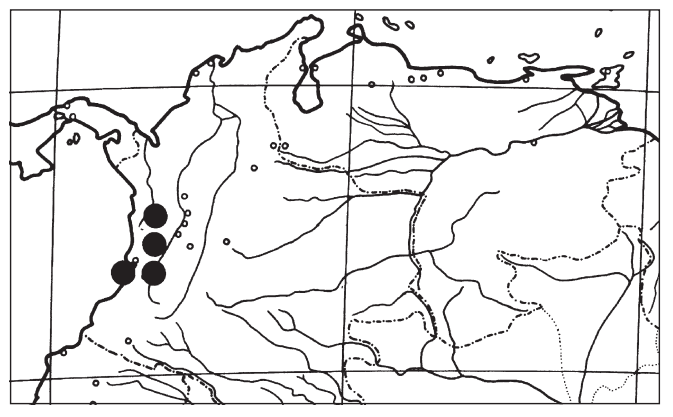

Map 13. Distribution of Pseudoxandra pacifica Maas. 
Distribution - Pacific coast of Colombia (Chocó and El Valle).

Habitat \& Ecology - In forests. At elevations up to $100 \mathrm{~m}$. Flowering: April and May; fruiting: January, April, and May.

Notes - Pseudoxandra pacifica is characterized by its wide leaves in combination with large fruits that dry brownish, rather than blackish as is the case in most species of the genus.

Two sterile collections, namely Faber-Langendoen et al.386 (CUVC, MO) and Van Rooden et al. 565 (U) from the state of El Valle, Colombia, might represent extreme forms of $P$. pacifica. They differ by a conspicuously long drawn-out (caudate) leaf apex (to 30-35 mm long), but as to leaf characters in general, they seem to agree well with this species.

\section{Pseudoxandra papillosa Maas, spec.nov. - Fig. 1, 12; Map 14}

Species foliis parvis verruculis propriis plerumque destitutis, monocarpiis breviter stipitatis notabilis. - Typus: Cid \& Lima 3699 (holo INPA; iso NY, U), Brazil, Amazonas: Mun. Novo Japurá, confluence of Río Traira and Río Apaporis, near Cachoeira Urumutum, 18 Nov. 1982.

Tree 10-12 m tall, c. $10 \mathrm{~cm}$ diam.; young twigs rather densely covered with appressed hairs to $2 \mathrm{~mm}$ long, very soon glabrous. Leaves: petiole $1-5 \mathrm{~mm}$ long, c. $0.5 \mathrm{~mm}$ diam.; lamina narrowly elliptic to narrowly ovate, $7-11$ by $2-3 \mathrm{~cm}$ (leaf index $3.5-4$ ), chartaceous, not verruculose (or with few scattered verruculae), shiny, blackish to dark green above, greenish to brownish green below, glabrous above, sparsely covered with appressed hairs to $2 \mathrm{~mm}$ long, microscopically papillate below, base acute to obtuse, with 2 vague angular projections on either side, apex gradually acuminate (acumen 5-10 mm long), secondary veins distinct, straight, $10-15$ on either side of primary vein, prominent above, angles with primary vein $70-75^{\circ}$, smallest distance of marginal vein from margin 1-1.5 mm. Inflorescences 1 -flowered, produced from leafless branches, only seen in post-anthesis stage; peduncles 1-2 mm long, fruiting peduncles $2 \mathrm{~mm}$ long; bracts 2-5, depressed ovate, c. $1 \mathrm{~mm}$ long, outer side rather densely covered with appressed hairs; pedicels 1.5-2 $\mathrm{mm}$ long, $1 \mathrm{~mm}$ diam., fruiting pedicels to $3 \mathrm{~mm}$ long, $2 \mathrm{~mm}$ diam.; sepals depressed ovate, $1-1.5$ by $2-3 \mathrm{~mm}$, outer side glabrous; petals, stamens, and carpels not seen. Monocarps 5-15, green in vivo when young, brown in sicco, globose, $8-10 \mathrm{~mm}$ diam., apex apiculate (apicle $0.1-0.2 \mathrm{~mm}$ long), wall $0.2-0.3$ $\mathrm{mm}$ thick, stipes $1-2$ by $1 \mathrm{~mm}$; fruiting receptacle subglobose, $2-3 \mathrm{~mm}$ diam. Seeds subglobose, $8-9 \mathrm{~mm}$ diam., middle brown.

Distribution - In the north-western part of the Amazon Region (Colombia and Brazil).

Habitat \& Ecology - In inundated forest (igapó), on clayey or clayey-sandy soil. At low elevations. Flowering time unknown; fruiting: August and November.

Vernacular names - Colombia: La-choó, No-o-kee-ree-ká.

Note - Pseudoxandra papillosa superficially looks like a species of Bocageopsis, and material of it had indeed been filed under that genus. It is characterized by small leaves that lack the tiny warts, normally characteristic for the genus, or with few scattered warts at most. Instead, the lower side of the dried lamina, when viewed under a low-power microscope (magnification about $50 \times$ ), is seen to be densely covered with minute papilla-like excrescences, rather than showing the smooth surface of other spe- 


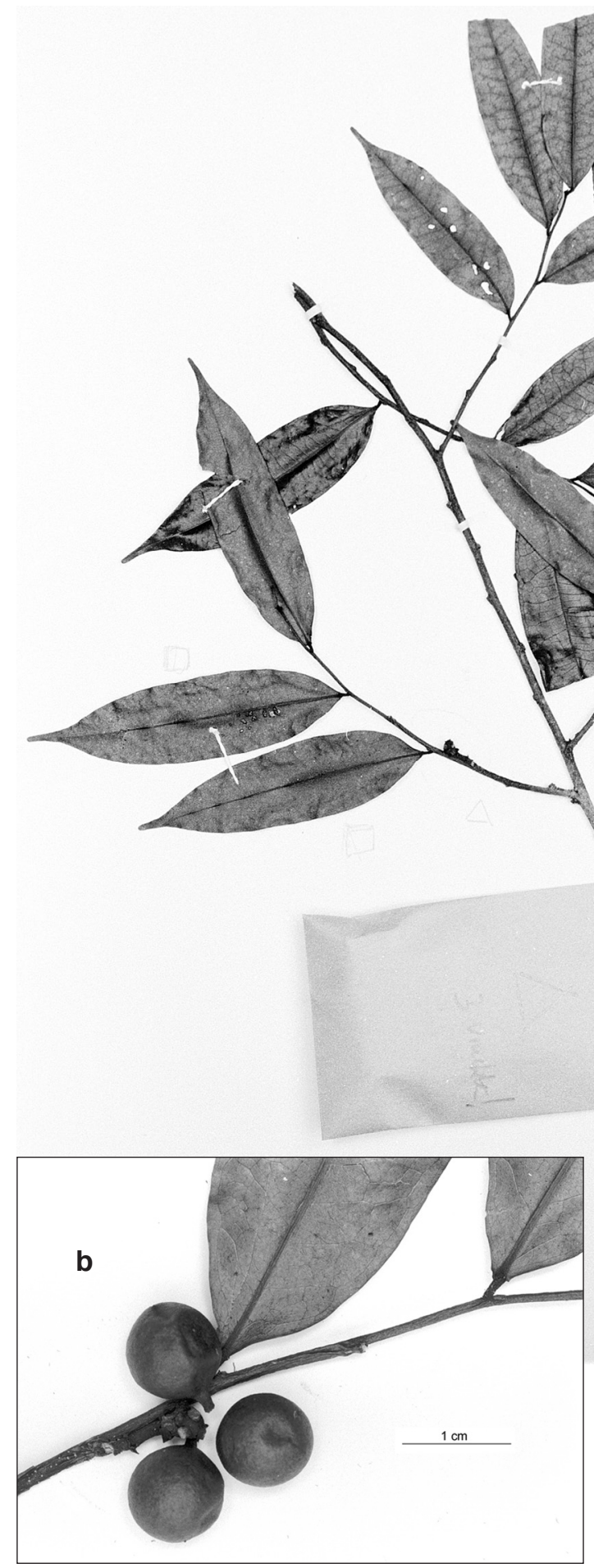

$5 \mathrm{~cm}$

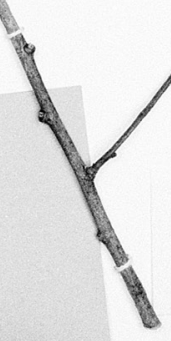

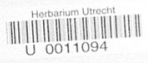

Instituto Nacional de Pesquisas da Planta do AMAZOL

Herb. 107.714

Bocageopsis sp.

Fronteira de Brasil e Colombia, Novo Japurä, confluencia dos rios Apaporis, proximo a cachoeira Uru ${ }_{1} 07^{\prime} \mathrm{S}, 699^{2} 5^{\prime} \mathrm{W}$. Mata de beira de argiloso.

Árvore de $10 \mathrm{~m}$ de altura $\times 10 \mathrm{~cm}$ de frutos em cachos imaturos verdes.

Fig. 12. Pseudoxandra papillosa Maas. a. Isotype specimen; b. close-up view of monocarps (Cid \& Lima 3699, U). 


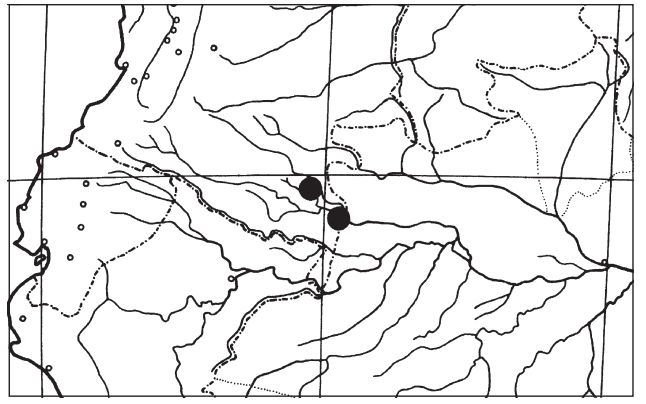

Map 14. Distribution of Pseudoxandra papillosa Maas.

cies of Pseudoxandra. This feature was observed by us only in P. papillosa. Another characteristic feature is found in the shortly stipitate monocarps, with the stipes not becoming longer than $2 \mathrm{~mm}$. Good flowering material is sought in order to complete the description of this species.

Other specimens examined:

BrAZIL. Amazonas: Mun. Novo Japurá, Vila Bittencourt, Rio Apaporis, Igarapé Preguiça, Cid \& Lima 3781 (INPA, NY, U).

COLOMBIA. Vaupés: Río Piraparaná, Schultes \& Cabrera R. 17009 (COAH, COL, F).

\section{Pseudoxandra parvifolia Maas, spec. nov. - Fig. 13; Map 15}

Species foliis pro genere parvis, ellipticis, apice obtusis vel rotundatis, raro emarginatis facile recognoscenda. - Typus: Berry et al. 6196 (holo U; iso F, MO, NY, TFAV, US, VEN, WIS), Venezuela, Amazonas: $1 \mathrm{~km}$ W of Budare, S bank of Upper Río Temi, 14 km SW of Yavita, 115 m, 10 March 1996.

Tree or shrub, 4-10 m tall, diameter unknown; young twigs glabrous. Leaves: petiole 2-5 mm long, 1-2 mm diam.; lamina elliptic, $5-7.5$ by $2.5-3.5 \mathrm{~cm}$ (leaf index $1.5-2.1$ ), coriaceous, not verruculose or sparsely verruculose mainly along the midvein, shiny, green to blackish above, pale brown below, glabrous above and below, base acute, with mostly distinct angular to toothlike projections on either side, apex obtuse to rounded, sometimes slightly emarginate, secondary veins indistinct, straight, 8-13 on either side of primary vein, prominent above, angles with primary vein $55-65^{\circ}$, smallest distance of marginal vein from margin $<1 \mathrm{~mm}$. Inflorescences 1-3-flowered, axillary; peduncles to $1 \mathrm{~mm}$ long and thick, fruiting peduncles to $\{-2\} \mathrm{mm}$ long; bracts $2-5$, broadly ovate, $1-2 \mathrm{~mm}$ long, outer side sparsely covered with appressed hairs; pedicels $1-2 \mathrm{~mm}$ long, $1\{-1.5\} \mathrm{mm}$ diam., fruiting pedicels to $\{-3\} \mathrm{mm}$ long, $1.5\{-2\} \mathrm{mm}$ diam.; sepals shallowly triangular, $1-2$ by $2-3 \mathrm{~mm}$, outer side sparsely covered with appressed hairs, soon glabrous, margins ciliate; petals pale yellow to cream in vivo, margins glabrous to ciliate, outer ones ovate to elliptic, $7-8$ by $5-6 \mathrm{~mm}$ (measured from pickled material), outer side glabrous to sparsely covered with appressed hairs, inner ones with a concave base and a slightly reflexed apex, leaving an opening of c. $2 \mathrm{~mm}$ between the three inner petals, $7-9$ by $4-5 \mathrm{~mm}$, glabrous; stamens $1.2-1.7$ mm long, connective appendage c. 1 by $0.2 \mathrm{~mm}$; carpels glabrous. Monocarps 1-6, green, maturing orange to red in vivo (collector's note; no mature monocarps seen by us), dark brown in sicco, globose, young ones 5-7 mm diam., apex apiculate (apicle 

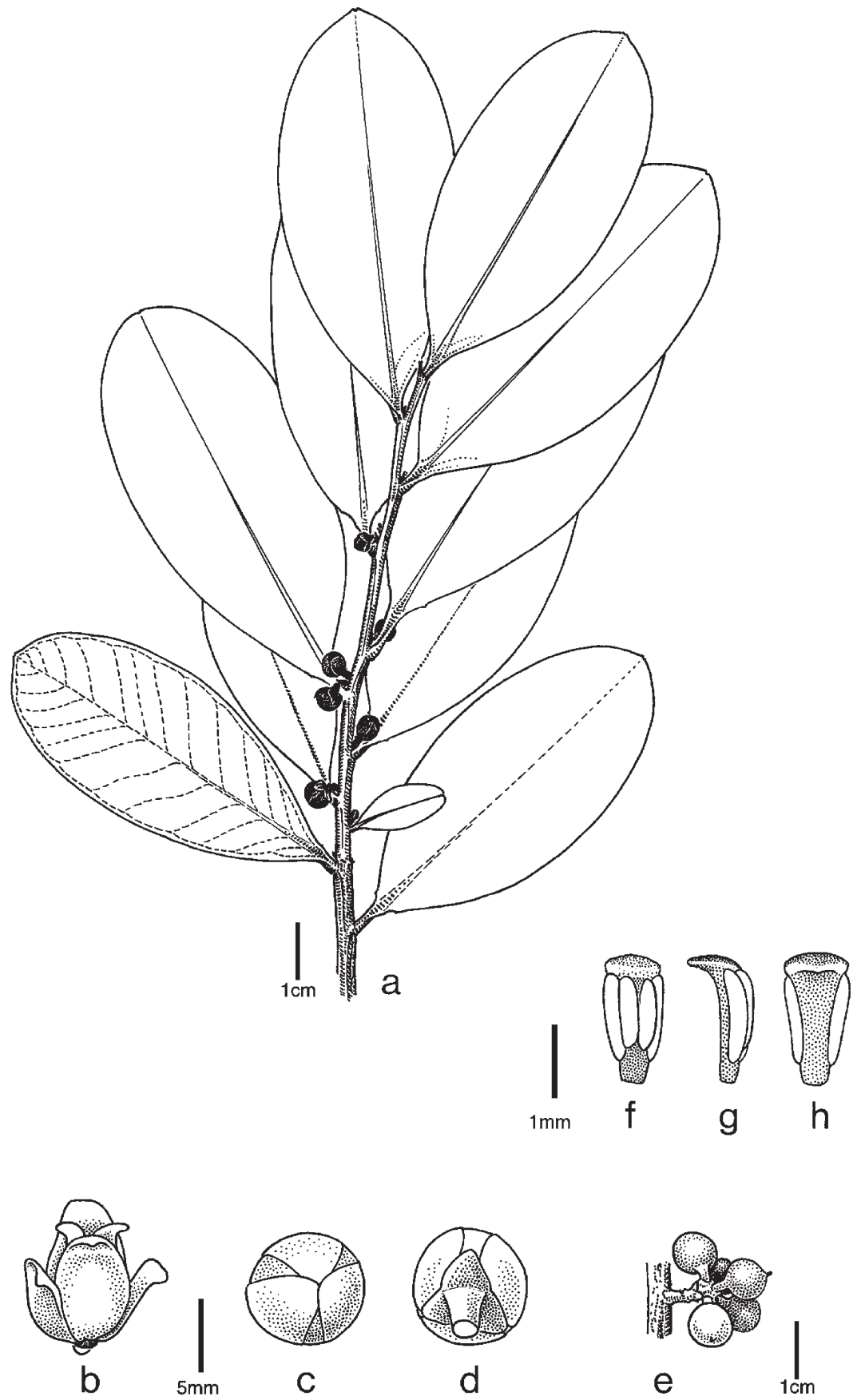

Fig. 13. Pseudoxandra parvifolia Maas. a. Flowering branch; b. flower; c. flower bud seen from above; d. flower bud seen from below showing, e.g., the three sepals; e. fruit; f. stamen in adaxial view; g. stamen in lateral view; h. stamen in abaxial view (Berry et al. 6196). 


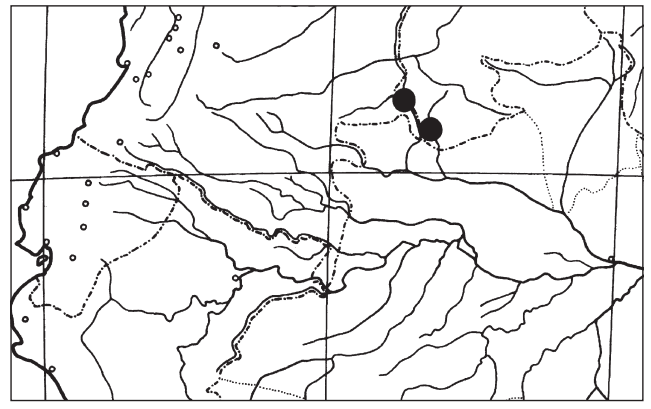

Map 15. Distribution of Pseudoxandra parvifolia Maas.

$<0.5 \mathrm{~mm}$ long), wall \{c. 0.5$\} \mathrm{mm}$ thick, stipes $3-7$ by $1 \mathrm{~mm}$; fruiting receptacle subglobose, c. $4 \mathrm{~mm}$ diam. Young seeds subglobose, $\{$ c. 5$\} \mathrm{mm}$ diam.

Distribution - Amazonian Venezuela.

Habitat \& Ecology - In riverine forest. At elevations of 90-115 m. Flowering: March and May; fruiting: February to May.

Vernacular name - Venezuela: Palo de boya.

Note - Pseudoxandra parvifolia is easily distinguished from its congeners by its small, elliptic leaves with an obtuse to rounded, or sometimes emarginate apex.

Other specimens examined:

VENEZUELA. Amazonas: Upper Río Temi, between Yavita and Budare, 110 m, Berry et al. 6261 (MO, U, WIS); Dep. Río Negro, 20 km from mouth of Río Varía, 90 m, Velazco 1720 (MO).

\section{Pseudoxandra pilosa Maas, spec. nov. - Fig. 14; Map 16}

$\mathrm{Ab}$ omnibus speciebus huius generis foliis et floribus pilis appressis vestitis differt. Typus: Cid et al. 9925 (holo INPA; iso NY, U), Brazil, Amazonas: Mun. Atalaia do Norte, Rio Javari, near border with Peru, 2-18 Jan. 1989.

Tree c. $8 \mathrm{~m}$ tall, diameter unknown; young twigs densely covered with erect and appressed, brown hairs. Leaves: petiole 2-3 mm long, 2-3 mm diam.; lamina narrowly oblong-elliptic to narrowly elliptic, $16-20$ by $3-4 \mathrm{~cm}$ (leaf index 5-5.3), chartaceous, densely verruculose, not shiny, dark brown above, brown below, sparsely to rather densely covered with erect and appressed hairs above, densely covered with erect and appressed hairs below, the appressed hairs to $3 \mathrm{~mm}$ long, base cordate to truncate, angular projections on either side more or less distinct, apex very gradually acuminate (acumen 10-20 mm long), secondary veins indistinct, straight, 20-25 on either side of primary vein, slightly prominent above, angles with primary vein $75-85^{\circ}$, smallest distance of marginal vein from margin 1-1.5 mm. Inflorescences produced from leafless branches, inflorescence structure unknown (only loose flower buds available); peduncles c. $5 \mathrm{~mm}$ long, c. $2 \mathrm{~mm}$ diam.; bracts 4 or 5, broadly ovate, 3-5 mm long, outer side densely covered with appressed, silky white hairs; pedicels extremely short, hidden under bracts; sepals broadly ovate, $10-12$ by $10-12 \mathrm{~mm}$, outer side densely covered with appressed, silky white hairs; petals green in vivo, densely covered with appressed, silky white hairs; stamens and carpels not seen. Monocarps and seeds not seen.

Distribution - Western Amazonian Brazil, near the border with Peru. 

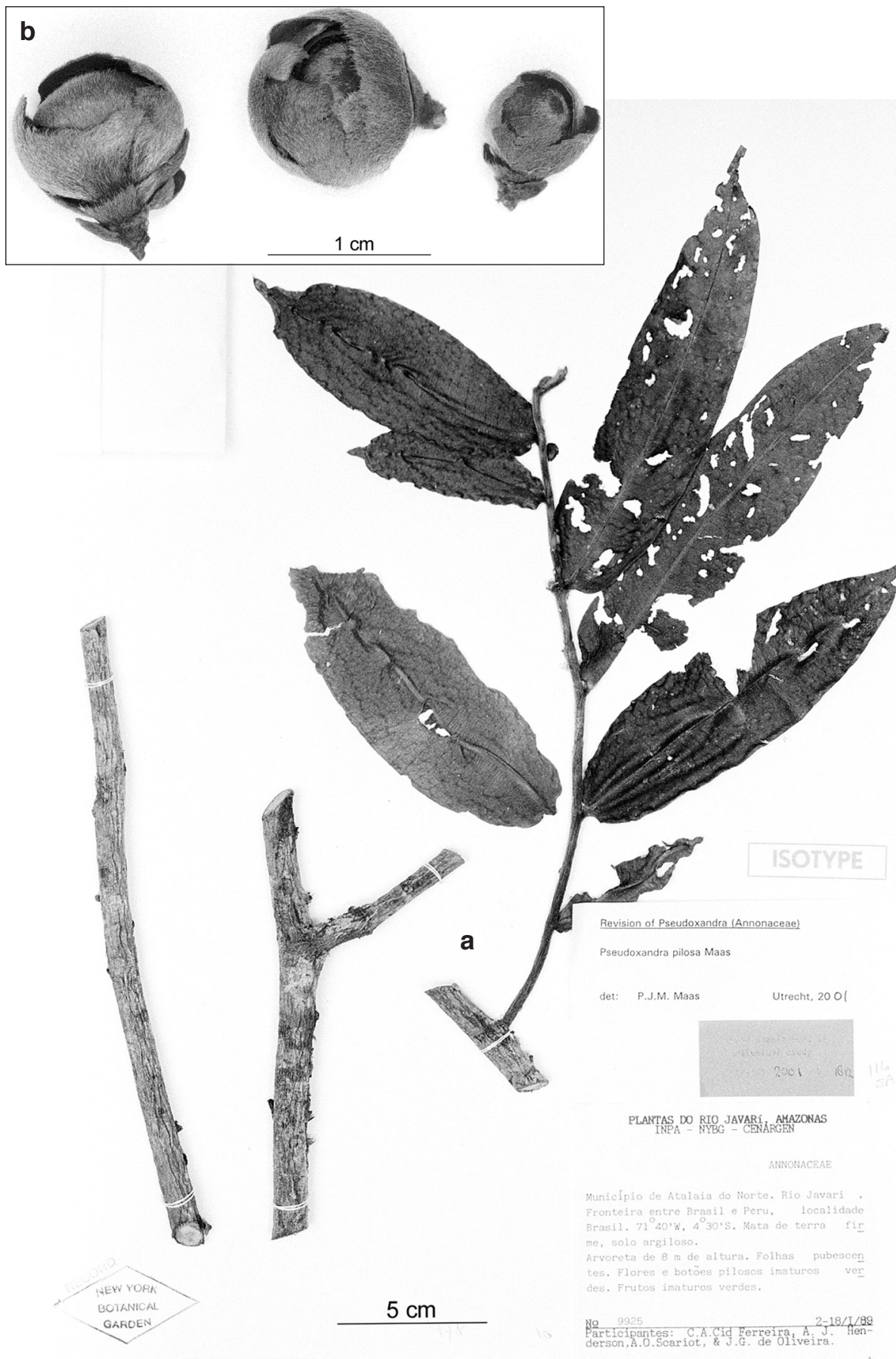

Fig. 14. Pseudoxandra pilosa Maas. a. Isotype specimen; b. close-up view of loose flower buds (Cid et al. 9925, NY). 


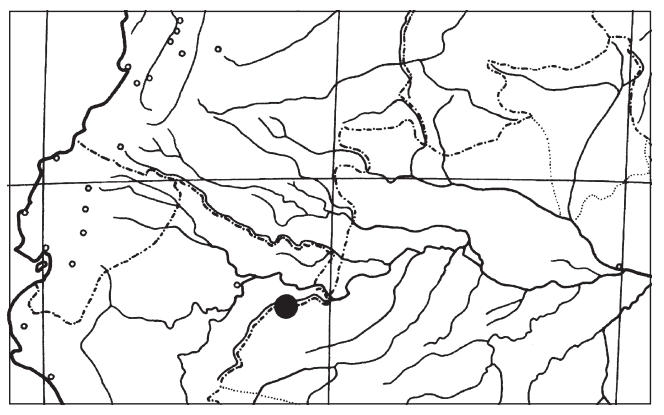

Map 16. Distribution of Pseudoxandra pilosa Maas.

Habitat \& Ecology - In non-inundated forest, on clayey soil. Elevation unknown. Flowering: January. Only known from the type collection.

Note - Pseudoxandra pilosa is easily distinguished from all other species of the genus by its dense indument on the lower side of the lamina, and on all of its floral parts. The most distinctive feature, however, is the cordate or truncate leaf base vs. acute to merely obtuse in other species of Pseudoxandra.

\section{Pseudoxandra polyphleba (Diels) R.E. Fr. - Map 17}

Pseudoxandra polyhleba (Diels) R.E. Fr. (1937) 230. - Unonopsis polyphleba Diels (1905) 131. - Cremastosperma polyphleba (Diels) R.E. Fr. (1931) 331. - Type: Ule 5628 (holo B, not seen; iso F, G, K, MG, S), Brazil, Acre: Rio Jurua-Mirim, Aug. 1901.

Tree, or very rarely a shrub (2-)4-15 $\mathrm{m}$ tall, 3.5-15(-35) cm diam.; young twigs very soon glabrous. Leaves: petiole 2-7 mm long, c. $1 \mathrm{~mm}$ diam.; lamina narrowly oblongelliptic to narrowly elliptic, $10-19$ by $3-6 \mathrm{~cm}$ (leaf index $2.9-3.4$ ), chartaceous, densely to rather densely verruculose, not shiny, glabrous above, glabrous below, rarely with some appressed hairs to $1 \mathrm{~mm}$ long near primary vein, base acute to obtuse, with or without 2 vague angular projections on either side, apex acuminate (acumen 5-15 mm long), secondary veins distinct, straight, $10-15$ on either side of primary vein, slightly prominent above, angles with primary vein $70-75^{\circ}$, smallest distance of marginal vein from margin 1-2 mm. Inflorescences 1-2(-4)-flowered, axillary or produced from leafless branches, rarely at the base of a lateral shoot; peduncles $1-1.5(-2) \mathrm{mm}$ long, fruiting peduncles $2-3(-4) \mathrm{mm}$ long; bracts $2-4$, depressed ovate, $0.5-1 \mathrm{~mm}$ long, outer side densely covered with appressed hairs; pedicels (1.5-)2-5 mm long, 0.5-1.5 mm diam., fruiting pedicels 2-8 mm long, to 1-3 mm diam.; sepals depressed ovatetriangular, $1-2$ by $2-3 \mathrm{~mm}$, outer side glabrous to sparsely covered with appressed hairs; petals yellow, cream, or white in vivo, outer ones ovate to broadly elliptic, 4-10 by $3-5 \mathrm{~mm}$, outer side glabrous, inner ones obovate to broadly elliptic, $3-8$ by $3-5$ $\mathrm{mm}$, outer side glabrous; stamens $1.5-1.7 \mathrm{~mm}$ long, connective appendage $0.5-0.7$ by 0.1-0.2 mm; carpels glabrous. Monocarps 5-20, green when young, maturing to yellow, red, and finally wine-red to almost black in vivo, brown and with an often shrivelled surface in sicco, globose, 10-15(-20) mm diam., apex rounded or apiculate (apicle $<0.5 \mathrm{~mm}$ long), glabrous, wall $0.2-0.3 \mathrm{~mm}$ thick, stipes $1-4(-7)$ by $1-1.5 \mathrm{~mm}$; fruiting receptacle depressed ovoid to depressed globose, 2-4 mm diam. Seeds subglobose to transversely ellipsoid, $8-13$ by $7-12 \mathrm{~mm}$, brown. 


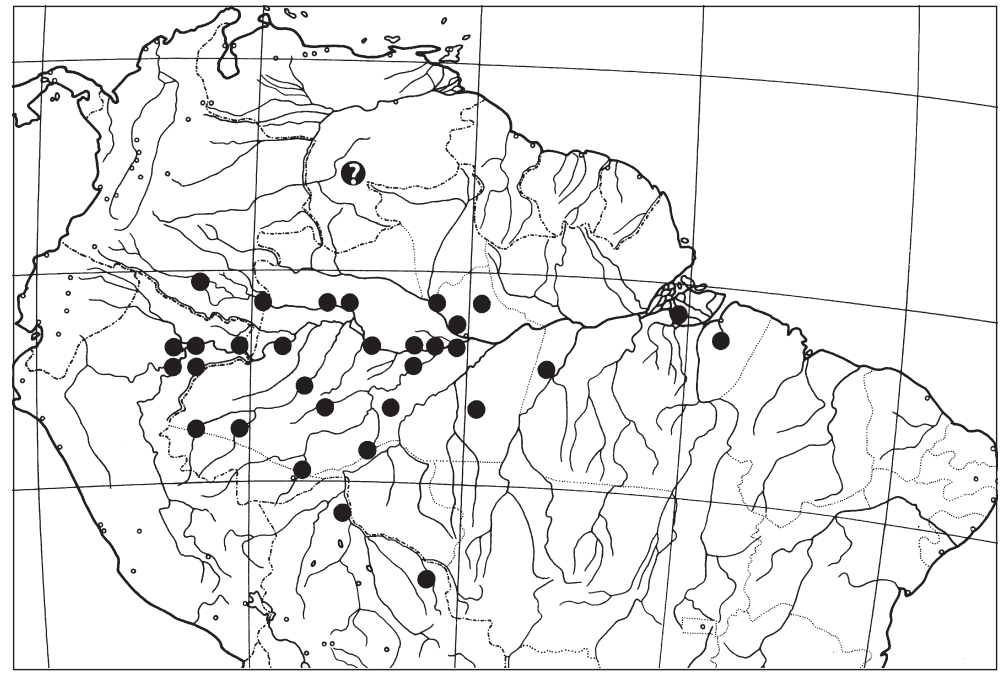

Map 17. Distribution of Pseudoxandra polyphleba (Diels) R.E. Fr.

Distribution - Amazonian parts of Colombia, Venezuela (?), Peru, Brazil, and Bolivia.

Habitat \& Ecology - In periodically inundated forest, on clayey soil. At elevations from sea level to $200 \mathrm{~m}$. Flowering: mainly from June to October; fruiting: throughout the year, but mainly from October to February.

Uses - Bark used for lashing (Peru, Mexia 6416). Bark (possibly?) used for house construction (Venezuela, Lister \& Colchester 678 - but see note on this collection below).

Vernacular names - Bolivia: Singa. Brazil: Envira, Envira amargosa, Envira branca, Envireira. Colombia: Cajao dujeku, Carguero de rebalse, Jinya mure. Peru: Bara, Barahuasca, Espintana. Venezuela: L'dapha.

Notes - Pseudoxandra polyphleba is a very common species in the inundated forests of the Amazon Region. It is distinguished by thin, verruculose leaves, narrow pedicels, very small flowers, glabrous petals, and brown and shrivelled (in sicco!), shortly stipitate monocarps. It is closest to P. lucida, which has much thicker leaves, hairy flowers, and thicker pedicels.

A sterile collection, Lister \& Colchester 678 (K), from Venezuela, Amazonas, Wankéhe, Caño Marueta, $110 \mathrm{~m}$ probably belongs here. It is marked with ? on the distribution map.

Prance et al. 6841 (INPA) from Rio Pacaás Novas, Rondônia, Brazil, resembles this species in its completely glabrous flowers, but has very small leaves (6-7 by $2-2.5$ $\mathrm{cm})$.

17. Pseudoxandra revoluta Maas, spec. nov. - Fig. 15; Map 18

Species foliis cum petiolis crassis, marginibus plusminusve revolutis distincta. - Typus: J.C. Ruíz 1314 (holo MO; iso K), Peru, Loreto: Distr. Iquitos, Puerto Almendras, Río Nanay, 122 m, 27 April 1988. 


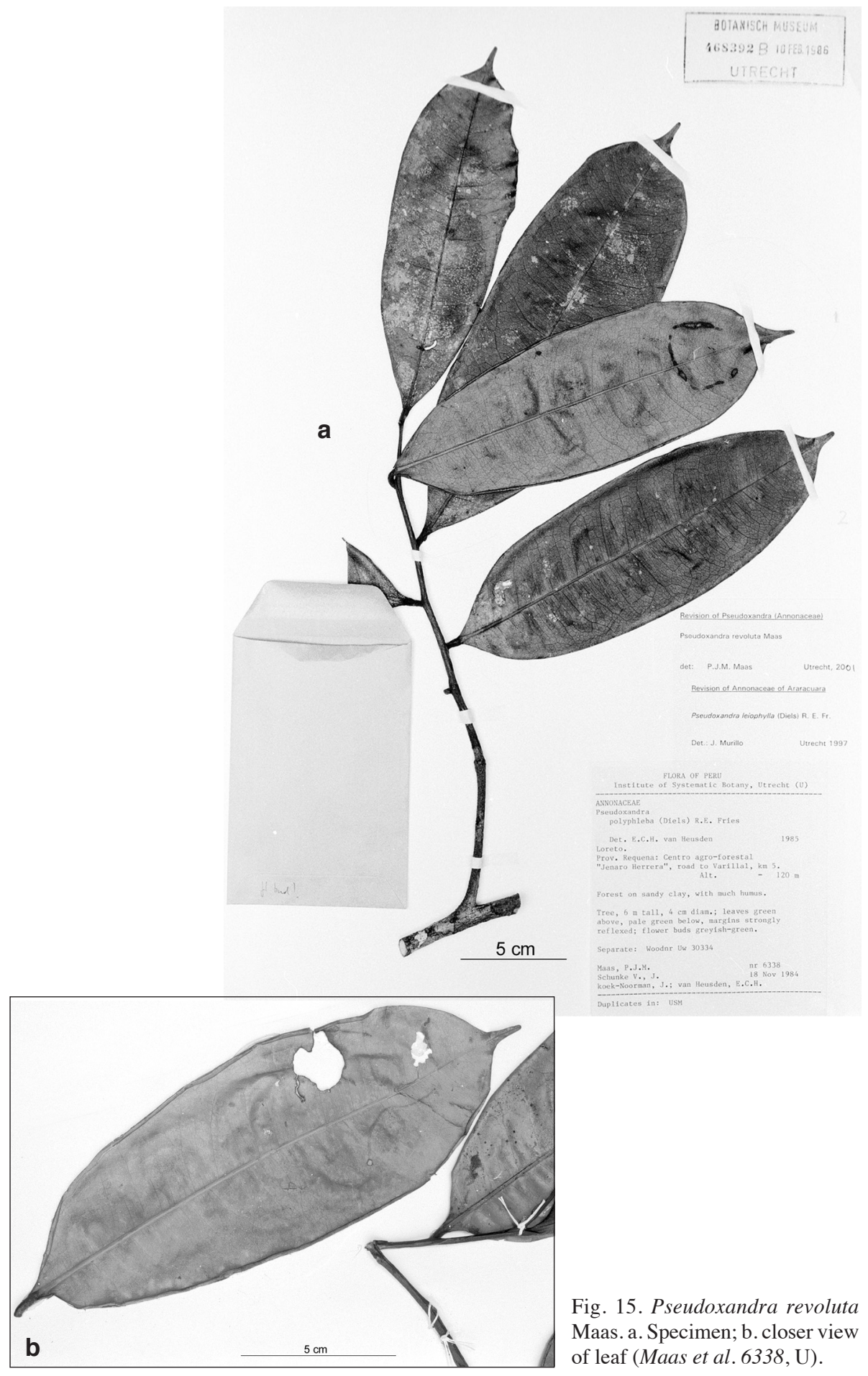


Tree 4-10 m tall, c. 4 cm diam.; young twigs glabrous. Leaves: petiole 5-10 mm long, $2-3 \mathrm{~mm}$ diam.; lamina narrowly obovate to narrowly elliptic, $15-27$ by $4.5-8.5(-11)$ $\mathrm{cm}$ (leaf index 2.7-3.4), coriaceous, rather densely to sparsely and coarsely verruculose, not shiny, greyish green to brownish green above, pale brown to brown below, glabrous above, glabrous to very sparsely covered with some appressed hairs near the primary vein below, base acute and attenuate, rarely obtuse, margins revolute over most of their length, without angular projections on either side, apex acuminate (acumen 5-15 mm long), secondary veins indistinct, straight, 15-20 (hardly countable) on either side of primary vein, slightly prominent above, angles with primary vein $80-85^{\circ}$, smallest distance of marginal vein from margin 1.5-2 mm. Inflorescences 1- or 2- (or 3-)flowered, axillary or produced from leafless branches. Peduncle $2 \mathrm{~mm}$ long (only one flower bud seen), fruiting peduncles $2-4 \mathrm{~mm}$ long; bracts 3 or 4 , depressed ovate, c. $2 \mathrm{~mm}$ long, outer side rather densely to densely covered with appressed hairs; pedicels c. $3 \mathrm{~mm}$ long, c. $1.5 \mathrm{~mm}$ diam., fruiting pedicels $2-5 \mathrm{~mm}$ long, (1.5-)2-3 mm diam.; sepals depressed ovate, $2-3$ by $4-5 \mathrm{~mm}$, outer side rather densely covered with appressed hairs; petals greyish green in bud in vivo, not measured, outer side of inner and outer ones rather densely covered with appressed hairs (in bud); stamens and carpels not seen. Monocarps 5-15, yellow, orange, red to black in vivo, brown in sicco, globose, $10-15 \mathrm{~mm}$ diam., apex rounded or apiculate (apicle c. $0.5 \mathrm{~mm}$ long), wall $0.2-0.3$ mm thick, stipes $4-5$ by $1-1.5 \mathrm{~mm}$; fruiting receptacle globose, 5-7 mm diam. Seeds transversely ellipsoid, $8-9$ by $9-10 \mathrm{~mm}$, dark brown.

Distribution - Amazonian Peru.

Habitat \& Ecology - In non-inundated forest, mostly on sandy soil. At elevations of 120-170 m. Flowering: November (young buds); fruiting: April, July, August, and November.

Vernacular names - Peru: Anonilla, Vara.

Note - Pseudoxandra revoluta differs sharply from other species of this genus by its various leaf characteristics like a thick petiole (up to $3 \mathrm{~mm}$ ), an attenuate leaf base, and particularly by its revolute margins, a feature which is also well visible in the field. Mature flowers are unknown as yet. The angle between the secondary veins and the primary vein is quite large $\left(80-85^{\circ}\right)$.

\section{Selection of other specimens (10) examined:}

PERU. Loreto: Prov. Maynas, Estación Biologica Río Tahuaya, 120 m, E. Arévalo 590 (K); Centro Agro-forestal Jenaro Herrera, 180 m, Maas et al. 6338 (AMAZ, U); Requena, Sapuena, Jenaro Herrera, 170 m, Vásquez \& Jaramillo 10013 (MO).

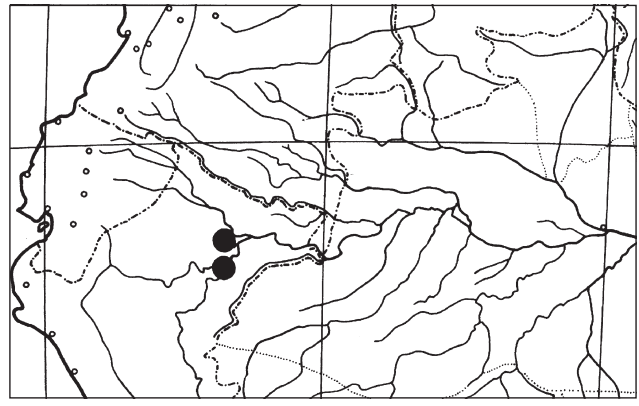

Map 18. Distribution of Pseudoxandra revoluta Maas. 

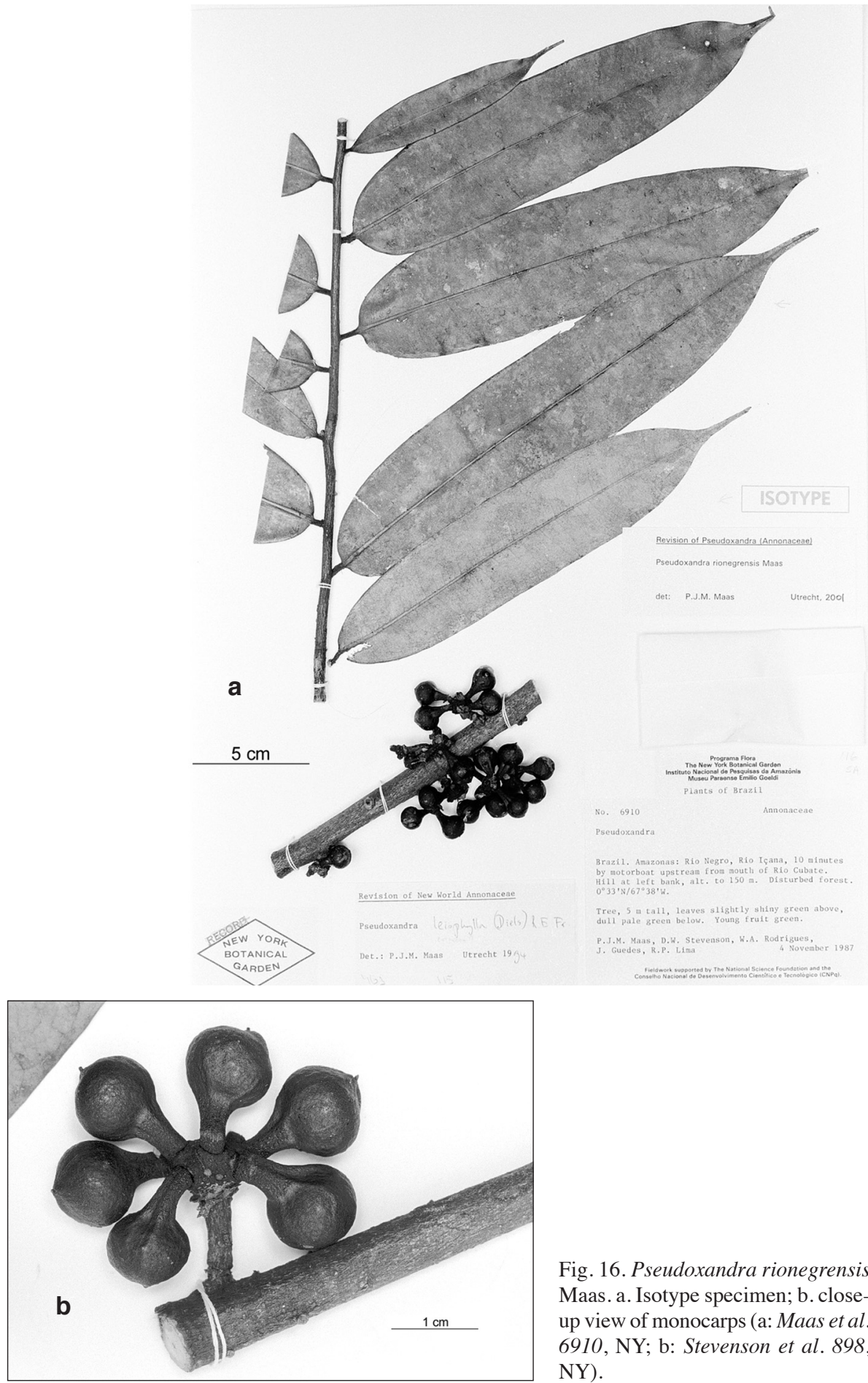

Fig. 16. Pseudoxandra rionegrensis Maas. a. Isotype specimen; b. closeup view of monocarps (a: Maas et al. 6910, NY; b: Stevenson et al. 898 NY). 


\section{Pseudoxandra rionegrensis Maas, spec. nov. - Fig. 16; Map 19}

Species foliis dense verruculosis, monocarpiis pariete crasso distincta. - Typus: Maas et al. 6910 (holo INPA; iso NY, RB, U), Brazil, Amazonas: Rio Negro, Rio Içana, 10 minutes by motorboat upstream from mouth of Rio Cubate, 150 m, 4 Nov. 1987.

Tree 4-5 m tall, diameter unknown; young twigs glabrous. Leaves: petiole 5-6 mm long, 1-2 mm diam.; lamina narrowly oblong-elliptic, $17-26$ by $3.5-6 \mathrm{~cm}$ (leaf index 4.3-5), coriaceous, densely, but minutely verruculose, slightly shiny, greyish green above, pale green below, glabrous above, sparsely covered with appressed hairs to $2 \mathrm{~mm}$ long below, particularly near margins and primary vein, base obtuse, with 2 vague angular projections on either side, apex long-acuminate (acumen 15-25 $\mathrm{mm}$ long, the tip itself obtuse), secondary veins indistinct, straight, hardly countable, c. 20 on either side of primary vein, flat to very slightly prominent above, angles with primary vein c. $80^{\circ}$, smallest distance of marginal vein from margin 1-1.5 mm. Inflorescences 1 - or 2-flowered, produced from leafless branches, flowers unknown; fruiting peduncles 2-3 mm long; no complete bracts seen, not countable, outer side of bract remnants densely covered with appressed hairs; fruiting pedicels $6-10 \mathrm{~mm}$ long, $3-4\{-6\} \mathrm{mm}$ diam.; sepals persistent, depressed ovate, $3-4$ by $5-6 \mathrm{~mm}$, outer side densely covered with appressed, brown hairs; petals, stamens, and carpels not seen. Monocarps 3-10, young ones green in vivo, black in sicco, subglobose, $8-12\{-20\} \mathrm{mm}$ diam., apex apiculate (apicle $<1 \mathrm{~mm}$ long), wall c. $1\{-3\} \mathrm{mm}$ thick, stipes $5-7$ by $1-3\{-6\} \mathrm{mm}$; fruiting receptacle subglobose, $5-8 \mathrm{~mm}$ diam. Seeds transversely ellipsoid, $12-15$ by 8-12 mm, brown.

Distribution - The Upper Rio Negro region of Amazonian Brazil.

Habitat \& Ecology - In non-inundated, high caatinga forest, on sandy soil. At elevations of up to $150 \mathrm{~m}$. Flowering time unknown; young fruits produced in November.

Note - Pseudoxandra rionegrensis is only known very locally from the Upper Rio Negro where, according to one of the labels, it occurs in non-inundated high caatinga forests. It is well recognizable by its green drying, densely and minutely verruculose leaves and its thick-walled fruits, which are black when dry. However, good flowering material is needed to complete the description of this species.

Other specimens examined:

BrazIL. Amazonas: Rio Negro, Rio Içana, Sero Grilo, 1 hour upstream by motorboat from confluence with Rio Negro, Stevenson et al. 898 (INPA, NY, U).

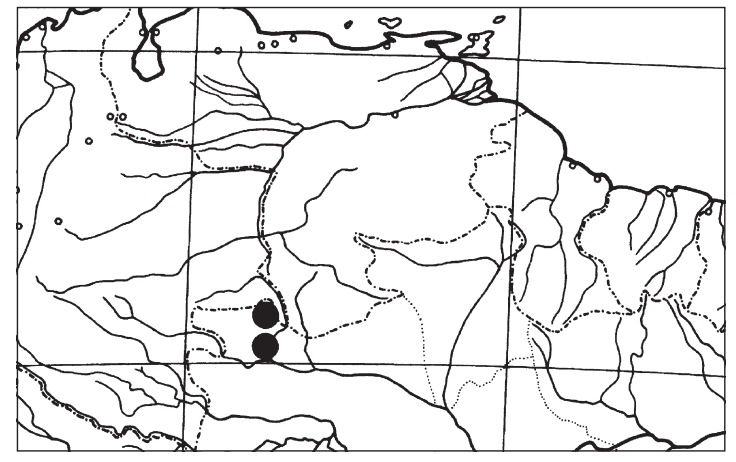

Map 19. Distribution of Pseudoxandra rionegrensis Maas. 


\section{Pseudoxandra sclerocarpa Maas - Map 20}

Pseudoxandra sclerocarpa Maas, in Maas et al. (1986) 271, f. 16. - Type: Hoyos \& Hernández 448 (holo U; iso MO), Colombia, Antioquia: Mun. San Luís, La Josephina, km 132 of Autopista from Medellín to Bogotá, 800 m, 28 Nov. 1983.

Tree 8-28 $\mathrm{m}$ tall, to $20 \mathrm{~cm}$ diam.; young twigs glabrous. Leaves: petiole 5-8 $\mathrm{mm}$ long, $1-1.5 \mathrm{~mm}$ diam.; lamina narrowly elliptic, $9-16$ by $2-4.5 \mathrm{~cm}$ (leaf index $3.5-4.5$ ), coriaceous, densely to sparsely verruculose (then often mainly near primary vein), slightly shiny, blackish to dark blackish green above, brown below, glabrous above, glabrous below, or with some scattered appressed hairs to $2 \mathrm{~mm}$ long mainly near primary vein, base acute to obtuse, with 2 usually distinct angular to toothlike projections on either side, apex acute to long-acuminate (acumen 5-15 mm long), secondary veins indistinct, straight, 11-16 on either side of primary vein, slightly prominent above, angles with primary vein $60-70^{\circ}$, smallest distance of marginal vein from margin 1-2 mm. Inflorescences 1- or 2- (or 3-)flowered, axillary or produced from leafless branches, rarely at the base of a lateral shoot; peduncles $1 \mathrm{~mm}$ long, fruiting peduncles $3-5 \mathrm{~mm}$ long; bracts 2-5, depressed ovate, 1-2 mm long, outer side rather densely covered with appressed hairs, margins ciliate; pedicels 1-4 mm long, 1-1.5 mm diam., fruiting pedicels $4-7 \mathrm{~mm}$ long, $2-5 \mathrm{~mm}$ diam.; sepals depressed ovate-triangular, $1.5-3$ by $2-4$ $\mathrm{mm}$, outer side glabrous, margins ciliate; petals green in vivo, outer ones ovate-elliptic, $7-10$ by $5-6 \mathrm{~mm}$, outer side subglabrous, margins ciliate, inner ones obovate, slightly concave, $10-13$ by $4.5-5.5 \mathrm{~mm}$, outer side glabrous, margins ciliate; stamens $2-2.5$ $\mathrm{mm}$ long, connective appendage c. 1.5 by $0.3 \mathrm{~mm}$; carpels glabrous. Monocarps $3-9$, green, maturing yellow to black in vivo, black in sicco, globose, $18-25 \mathrm{~mm}$ diam., apex rounded to apiculate (apicle 1-2 mm long), wall 2-3 mm thick, stipes 12-22 by 2.5-3 mm; fruiting receptacle depressed ovoid, 5-10 $\mathrm{mm}$ diam. Seeds transversely ellipsoid to globose, 7-13 by 11-15 mm, dark brown to blackish brown.

Distribution - The Colombian state of Antioquia.

Habitat \& Ecology - In forests. At elevations from 500-950 m. Flowering: November to March; fruiting: throughout the year.

Note - Pseudoxandra sclerocarpa is distinctive by its relatively large, thick-walled monocarps, in combination with a leaf base with distinct angular to toothlike projections on either side. Its connections need further study though.

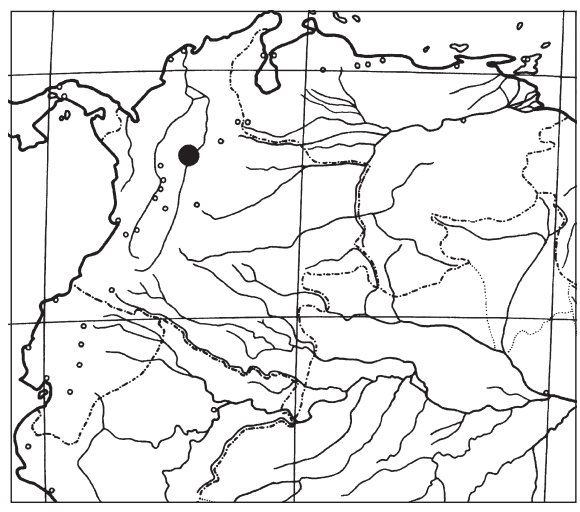

Map 20. Distribution of Pseudoxandra sclerocarpa Maas. 
20. Pseudoxandra spiritus-sancti Maas, spec.nov. - Fig. 2c, 17; Map 21

Pseudoxandrae bahiensis proxima, sed ab ea differt foliis minoribus chartaceis nec coriaceis, venis secundariis pro rata paucis, et pedicellis brevioribus. - Typus: Maas et al. 8833 (holo MBML; iso AAU, B, F, GB, K, LZ, MO, NY, P, U, US, WIS, WU), Brazil, Espirito Santo: Mun. Santa Teresa, Reserva Biológica de Santa Lucía, 800 m, 16 Febr. 1999.

Tree 5-15 m tall, 10-40 cm diam.; young twigs glabrous. Leaves: petiole 5-7 $\mathrm{mm}$ long, 1-2 mm diam.; lamina elliptic to narrowly elliptic, $7-15$ by $3-6 \mathrm{~cm}$ (leaf index 2-3), chartaceous, (rather) densely, or occasionally sparsely verruculose above, rather densely to sparsely verruculose, or smooth below, shiny, dark green to brownish green above, pale green to brown below, glabrous above, sparsely covered with appressed hairs to glabrous below, base acute to obtuse, without angular projections on either side, or sometimes these very indistinct, apex acute to very gradually acuminate (acumen 5-10 mm long), secondary veins indistinct, curved, 6-10 on either side of primary vein, prominent above, angles with primary vein $60-70^{\circ}$, loop-forming at right to obtuse angles, marginal vein absent, smallest distance between loops and margin 1-3 $\mathrm{mm}$. Inflorescences 1- or 2- (or 3-)flowered, axillary or produced from older leafless branches; peduncles $1 \mathrm{~mm}$ long, fruiting peduncles $2-3 \mathrm{~mm}$ long; bracts $3-5$, broadly ovate, 1-1.5 mm long, outer side sparsely covered with appressed hairs, margins ciliate; pedicels c. $1 \mathrm{~mm}$ long, 1-1.5 mm diam., fruiting pedicels $1-2 \mathrm{~mm}$ long, 2-4 mm diam.; sepals ovate to broadly ovate, $1.5-3$ by $2-4 \mathrm{~mm}$, outer side sparsely covered with appressed hairs, margins ciliate; petals green to yellow in vivo, outer ones ovate to broadly ovate, flat, $8-9$ by $4-7 \mathrm{~mm}$, outer side glabrous, inner ones concave (only visible in pickled material), broadly ovate when spread out, 7-9 by 5-9 mm, outer side glabrous, margins ciliate; stamens c. $2 \mathrm{~mm}$ long, connective appendage $0.7-1.5$ by 0.3-0.6 mm; carpels glabrous. Monocarps 1-15, reddish or brownish green to orange in vivo, black in sicco, globose, 14-25 mm diam., apex apiculate when young (apicle $<1 \mathrm{~mm}$ long), rounded when mature, wall 1-2 mm thick, stipes pale green to reddish in vivo, $5-15$ by $1-3 \mathrm{~mm}$; fruiting receptacle globose to depressed ovoid, $2-5 \mathrm{~mm}$ diam. Seeds globose to depressed globose, $12-15$ by $10-15 \mathrm{~mm}$, shiny brown.

Distribution - The Brazilian state of Espirito Santo.

Habitat \& Ecology - In low or high forest, found in association with many palms and terrestrial and epiphytic Bromeliaceae. At elevations from 650-800 m. Flowering: November to February; fruiting: October to February.

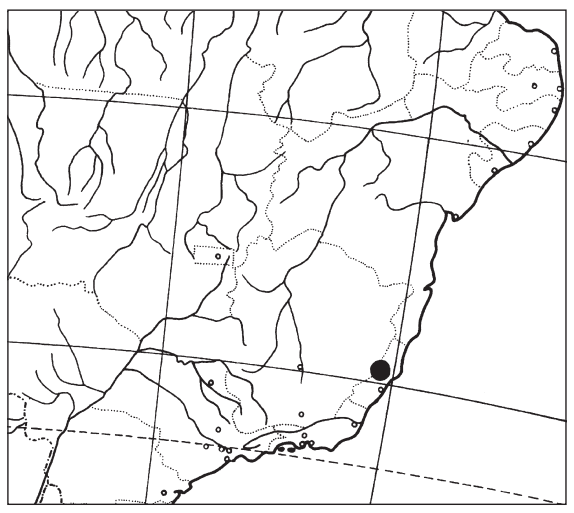

Map 21. Distribution of Pseudoxandra spiritussancti Maas. 


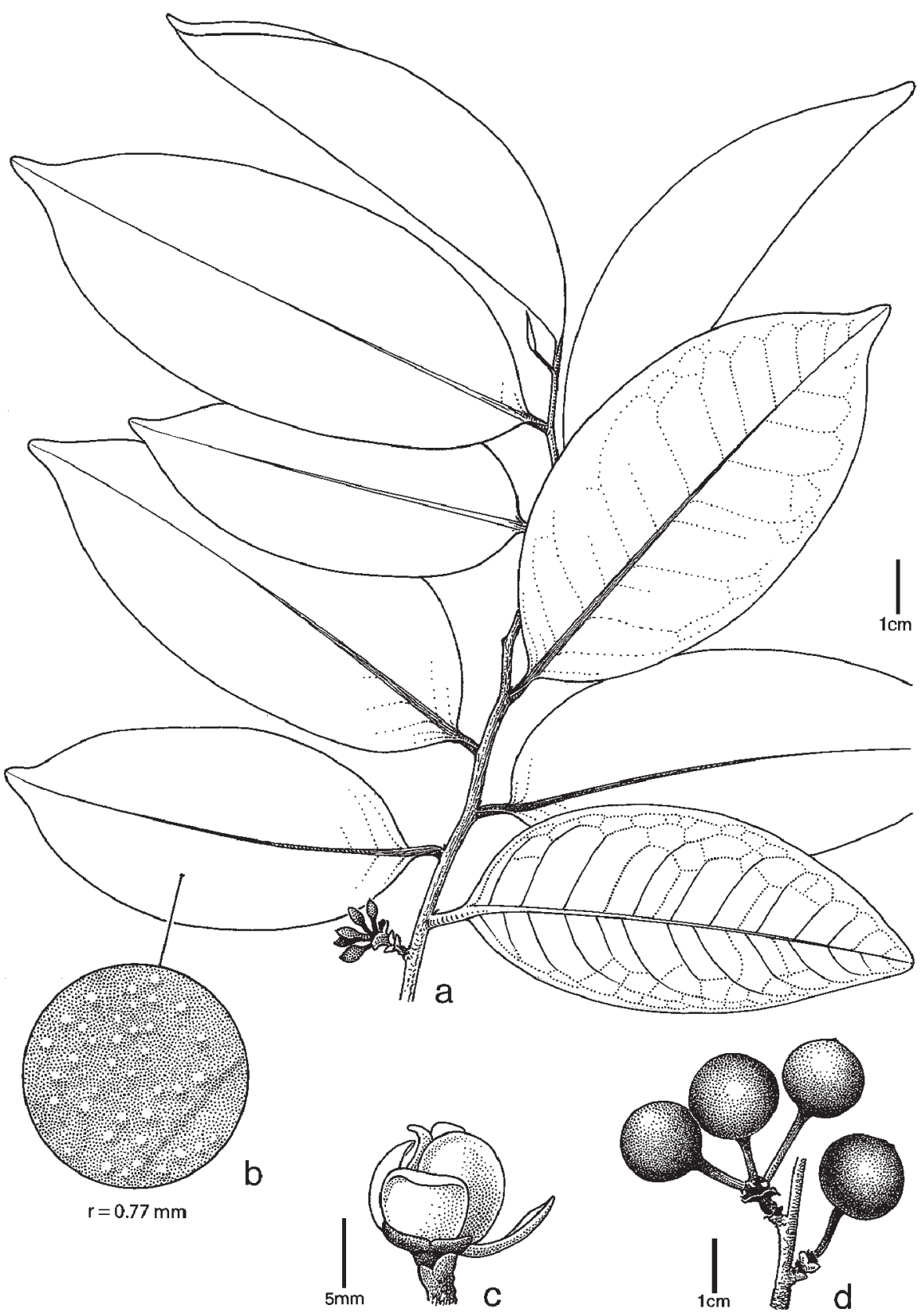

Fig. 17. Pseudoxandra spiritus-sancti Maas. a. Fruiting branch; b. leaf surface enlarged showing warts; c. flower; d. fruits (a-c: Maas et al. 8833; d: Kollmann et al. 1257). 
Note - Pseudoxandra spiritus-sancti is endemic to the Brazilian state of Espirito Santo. Its closest neighbour is P. bahiensis, from Bahia. It cannot be confused with the latter species because of its much smaller leaves with 6-10 (instead of 12-15) secondary veins. The leaves are chartaceous in this species and coriaceous in $P$. $b a$ hiensis. Moreover, the flower stalk of P. spiritus-sancti is shorter than that of the other species.

Selection of other specimens (9) examined:

BRAZIL. Espirito Santo: Mun. Santa Teresa, Aparecidinha, grounds of Luiz Bringhenti, $750 \mathrm{~m}$, Kollmann et al. 911 (MBML, U); Mun. Santa Teresa, Santo Antônio, grounds of Bosa, 750 m, Kollmann et al. 721 (MBML, U); Mun. Santa Teresa, Valsugana Velha, Reserva Biológica de Santa Lucía, TreeA1P102N2308, 650 m, Maas et al. 8835 (MBML, U).

\section{Pseudoxandra vallicola Maas, spec. nov. - Fig. 18; Map 22}

Species foliis densissime verruculosis praeterea basi manifeste bidenticulatis distincta. - Typus: Monsalve B. 168 (holo U; iso MO), Colombia, El Valle: Bajo Calima, Concesión Pulpapel/Buenaventura, 100 m, 9 Aug. 1984.

Tree 10-30 m tall, c. $10 \mathrm{~cm}$ diam.; young twigs glabrous, except for some scattered, appressed hairs. Leaves: petiole 5-10 mm long, 1-2 mm diam.; lamina narrowly oblong-elliptic, $13-22$ by $3-5 \mathrm{~cm}$ (leaf index 3.7-4.6), coriaceous, very densely verruculose, slightly shiny, blackish above, dark brown below, glabrous above, glabrous below except for some scattered appressed hairs to $2 \mathrm{~mm}$ long along primary vein, base obtuse, generally with 2 distinct angular to toothlike projections on either side, apex acute to slightly acuminate (acumen 5-10 mm long), secondary veins indistinct, straight, 15-20 on either side of primary vein, flat above, poorly visible below, angles with primary vein $70-80^{\circ}$, smallest distance of marginal vein from margin $2-3 \mathrm{~mm}$. Inflorescences 1- or 2-flowered, axillary or produced from leafless branches; peduncles $1 \mathrm{~mm}$ long, fruiting peduncles 3-6 mm long; bracts 3-6, depressed ovate, $1.5-3 \mathrm{~mm}$ long, outer side rather densely covered with appressed hairs; pedicels obconical, 1.5-2 $\mathrm{mm}$ long, 1.5-2 $\mathrm{mm}$ diam., fruiting pedicels 3-6 $\mathrm{mm}$ long, 3-4 mm diam.; sepals very broadly to depressed ovate-triangular, $2.5-3$ by $3-4 \mathrm{~mm}$, outer side glabrous; petal colour in vivo unknown, black in sicco, outer petals ovate, $7-10$ by $5-6 \mathrm{~mm}$, outer side glabrous, inner ones narrowly elliptic, with a concave base, apex reflexed,

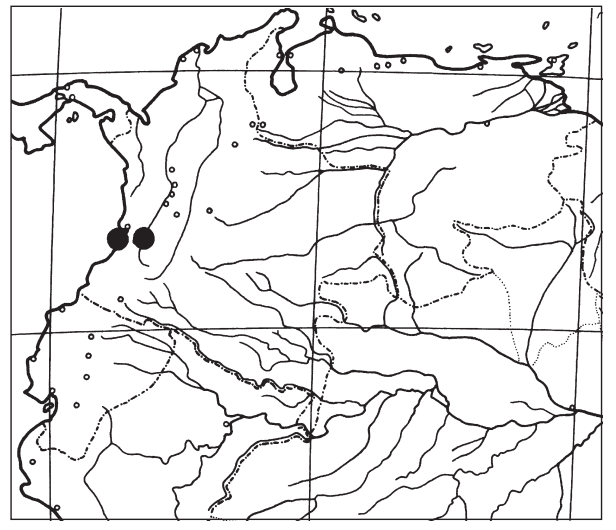

Map 22. Distribution of Pseudoxandra vallicola Maas. 


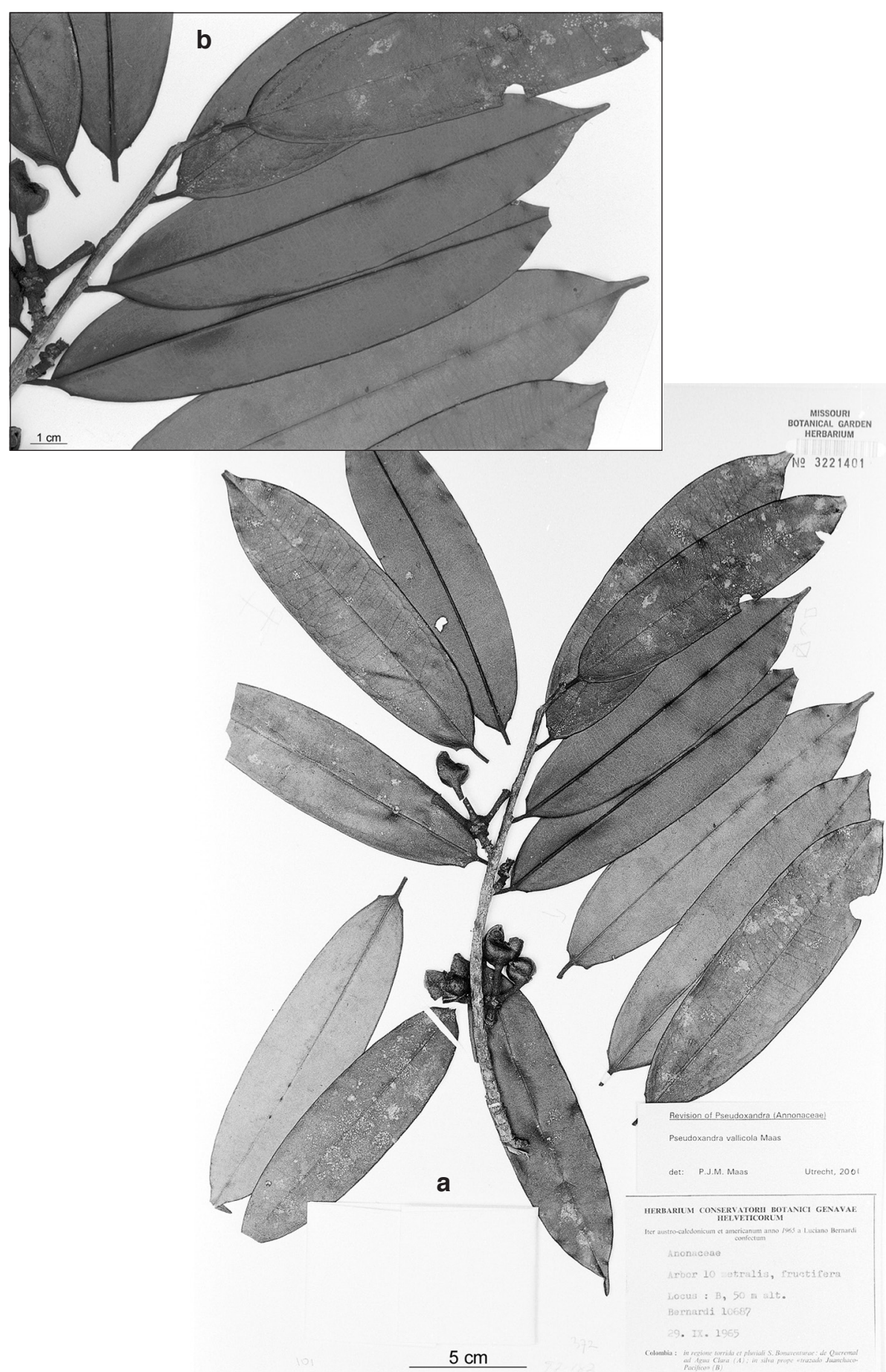

Fig. 18. Pseudoxandra vallicola Maas. a. Specimen; b. closer view of leaves (Bernardi 10687, MO). 
$8-10$ by $3-4 \mathrm{~mm}$, outer side glabrous; stamens $1.8-2.5 \mathrm{~mm}$ long, connective appendage c. 1 by $0.3 \mathrm{~mm}$; carpels c. 10, glabrous. Monocarps $8-10$, green in vivo, black in sicco, subglobose, $10-20 \mathrm{~mm}$ diam., apex apiculate (apicle c. $1 \mathrm{~mm}$ long), wall c. $1 \mathrm{~mm}$ thick, stipes $10-15$ by $2-3 \mathrm{~mm}$; fruiting receptacle depressed ovoid, $5-8 \mathrm{~mm}$ diam. Seeds not seen.

Distribution - The Colombian department of El Valle.

Habitat \& Ecology - In primary, non-inundated rain forest. At elevations of up to 100 m. Flowering: February; fruiting: August.

Vernacular name - Colombia: Cargadero.

Notes - Tree inhabited by 'scale-insect-tending' ants (Juncosa 2137).

Pseudoxandra vallicola is quite characteristic by its very densely verruculose lamina with distinct angular to toothlike projections. It looks superficially similar to the Amazonian species $P$. coriacea and $P$. obscurinervis, but it differs from both species by longer pedicels and stipes, and in some leaf characters.

Selection of other specimens (5) examined:

CoLOMBIA. EI Valle: Buenaventura,Agua Clara, near 'trazado Juanchaco-Pacifico', 50 m, Bernardi 10687 (G, MO); Bajo Calima, road to Juanchaco Palmeras, 50 m, Gentry et al. 48357 (CUVC, MO, U); Mun. Buenaventura, Cartón de Colombia, near Bajo Calima, 50-100 m, Juncosa 2137 (CUVC, $\mathrm{MO}, \mathrm{U})$.

\section{Pseudoxandra williamsii (R.E. Fr.) R.E. Fr. - Fig. 19; Map 23}

Pseudoxandra williamsii (R.E. Fr.) R.E. Fr. (1937) 227, f. 2b, c. - Cremastosperma williamsii R.E. Fr. (1934) 206. - Type: Ll. Williams 3960 (holo F; iso S), Peru, Loreto: Yurimaguas, Recreo, 23 Oct. 1929.

Shrub of unknown height and diameter; young twigs densely covered with greyish white appressed hairs, soon glabrous. Leaves: petiole 4-5 mm long, 1-1.5 mm diam.; lamina narrowly oblong-elliptic, 16-20 by 4-5 cm (leaf index 4), chartaceous, not verruculose, shiny, brown above and below, sparsely covered with appressed hairs to $2 \mathrm{~mm}$ long above, soon glabrous, sparsely covered with appressed hairs to $2 \mathrm{~mm}$ long below, mainly along the primary vein, base obtuse, without angular projections on either side, apex acuminate (acumen 5-15 mm long), secondary veins distinct, curved, 10-12

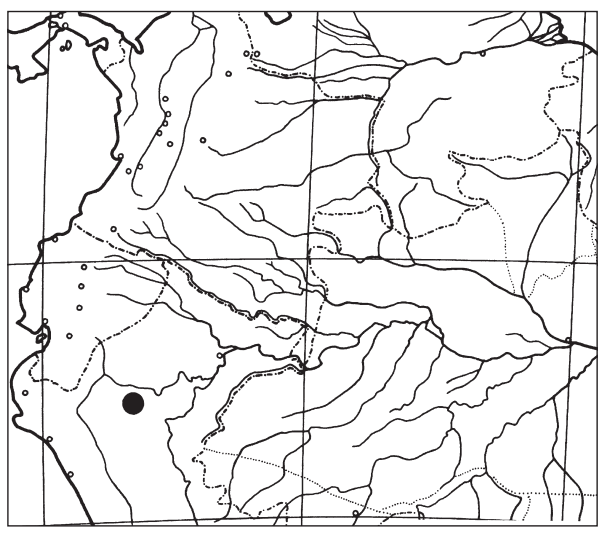

Map 23. Distribution of Pseudoxandra williamsii (R.E. Fr.) R.E. Fr. 


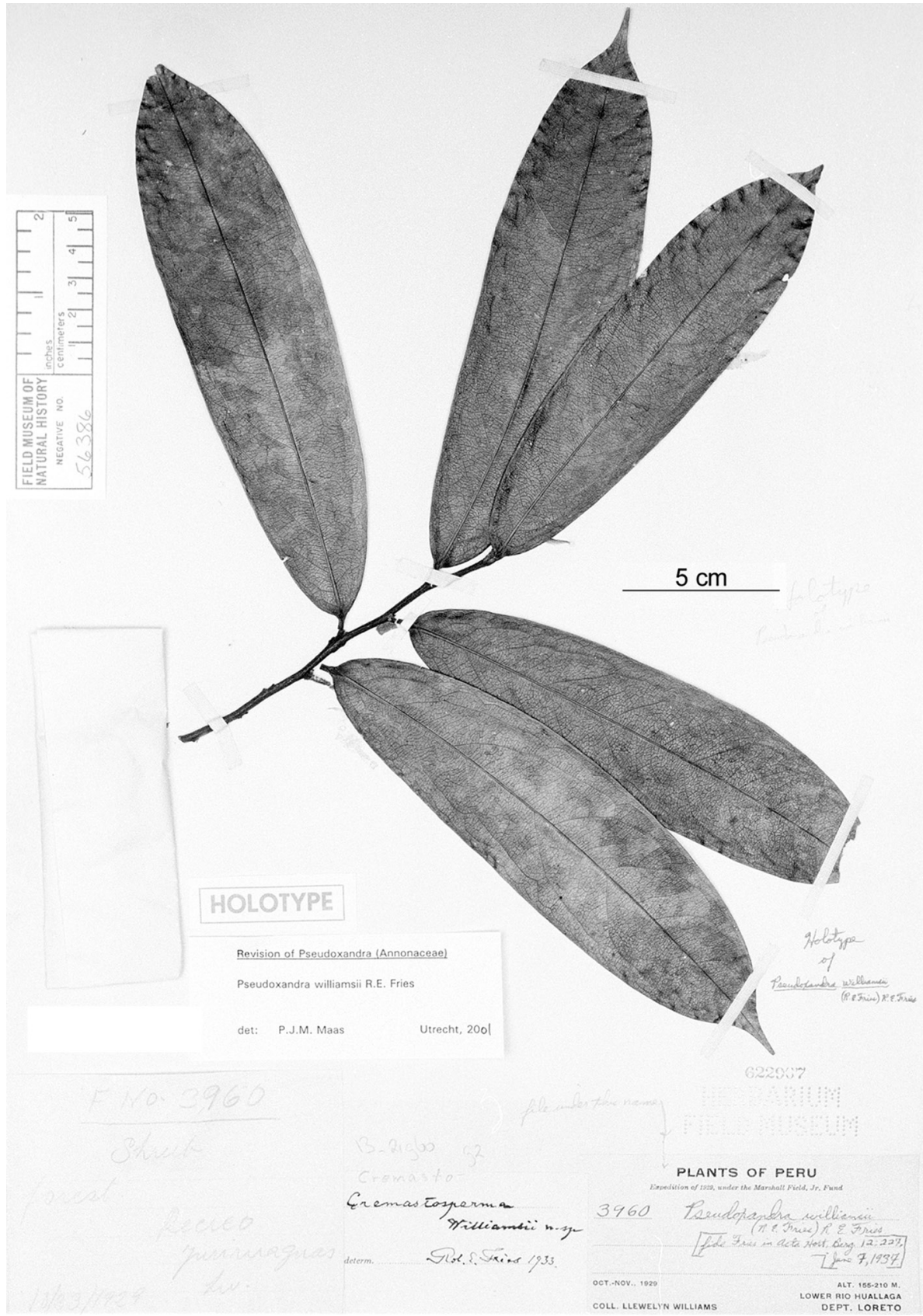

Fig. 19. Pseudoxandra williamsii (R.E. Fr.) R.E. Fr. Holotype specimen (Ll. Williams 3960, F). 
on either side of primary vein, prominent above, angles with primary vein $45-50^{\circ}$, smallest distance of marginal vein from margin 4-6 mm. Inflorescence structure not observable, only detached flowers seen; peduncles 2-4 mm long, 1.5-2 mm diam.; bracts $6,2.5 \mathrm{~mm}$ long, outer side densely covered with greyish white appressed hairs; pedicels $<1 \mathrm{~mm}$ long (hidden by uppermost bracts), 2-3 mm diam.; sepals depressed ovate, c. 5 by c. $8 \mathrm{~mm}$, outer side densely covered with greyish white appressed hairs; petal colour unknown in vivo, outer ones broadly ovate, $11-12$ by c. $9 \mathrm{~mm}$, outer side densely covered with greyish white appressed hairs, inner ones strongly concave, broadly ovate, $6-7$ by $5-6 \mathrm{~mm}$, outer side glabrous except for a densely hairy zone from the base to the apex; stamens 3.5-4 mm long, connective appendage discoid; carpels subglabrous. Monocarps and seeds not seen.

Distribution - Amazonian Peru, only known from the type collected in the Yurimaguas region.

Habitat \& Ecology - In forest. Elevations from 155-210 m. Flowering: October.

Note - Pseudoxandra williamsii is only known from one very poor collection, consisting of a leafy branch and some detached flowers. Its closest ally seems to be P. acreana, from which it differs by lack of the curly hairs on the lamina and by smaller sepals. From P. duckei (occurring in Central Amazonian Brazil, near Manaus) it differs by its somewhat larger leaves; moreover the angle of secondary veins with the primary vein is somewhat larger in $P$. duckei $\left(50-65^{\circ}\right.$ vs. $45-50^{\circ}$ in $P$. williamsii).

\section{INSUFFICIENTLY KNOWN SPECIES}

\section{Pseudoxandra spec. A - Map 24}

Tree c. $6 \mathrm{~m}$ tall, diameter unknown; young twigs glabrous. Leaves: petiole $2-3 \mathrm{~mm}$ long, c. $0.5 \mathrm{~mm}$ diam.; lamina narrowly ovate, $10-12$ by $1.5-1.7 \mathrm{~cm}$ (leaf index $5.3-8$ ), chartaceous, not verruculose, not shiny, dark brown above, pale brown below, glabrous above, sparsely covered with appressed hairs up to $1 \mathrm{~mm}$ long when young below, very soon glabrous, base obtuse, in some leaves acute, with 2 angular to toothlike projections on either side, apex gradually and long-acuminate (acumen 15-30 mm long, hardly measurable), secondary veins very indistinct, straight, c. 20 (hardly countable, 18-23

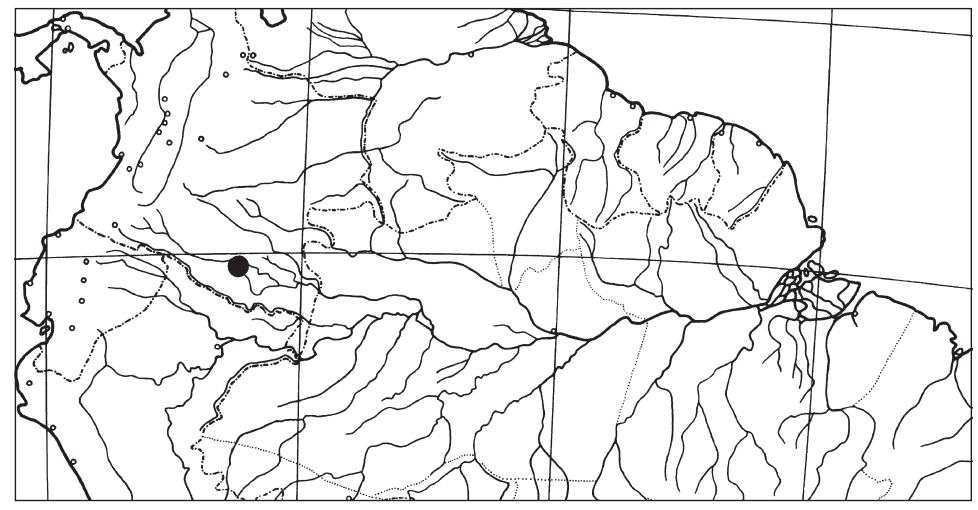

Map 24. Distribution of Pseudoxandra spec. A. 
according to Murillo-A.) on either side of primary vein, flat above, angles with primary vein $75-80^{\circ}$, smallest distance of marginal vein from margin $<1 \mathrm{~mm}$. Inflorescences, monocarps, and seeds not seen.

Distribution - Amazonian Colombia.

Habitat \& Ecology - In non-inundated forest, on clayey soil. At low elevations. Only vegetative collections seen.

Vernacular names - Colombia: Carguero, 'J+rida iviniai'.

Notes - Two distinctive specimens with very narrow leaves (to $1.5 \mathrm{~cm}$ wide) resemble those of Oxandra xylopioides quite a bit. Because of the presence of a marginal vein we have included the material in Pseudoxandra so far. The venation in the lamina is very obscure and it is hardly possible to count the veins (cf.P.obscurinervis). Formal description must wait until fertile material becomes available for study.

This species is cited as "Pseudoxandra sp A" in Murillo-A. \& Restrepo (2000). According to them the lamina is verruculose ("abundantamente verrucosa"), but the present authors could not observe any warts, despite the lamina having some rough appearance.

\section{Specimens examined:}

Colombia. Caquetá: Araracuara, trail to Río Yarí, Murillo-A. \& Román O.582, 616 (U), 11 July 1996.

\section{ACKNOWLEDGEMENTS}

We thank all curators of herbaria who made material available to us. We are indebted to Mr. Hendrik Rypkema (Utrecht) who made the drawings and the final version of the distribution maps. We are greatly indebted to Mr. Dew Makhan (Utrecht) who gave us valuable assistance during the initial sorting of the material and who set up a database of all collections. Our thanks also go to Mr. Philip Silverstone-Sopkin (CUVC) and Mr. José Murillo (COL) for providing information on some Colombian specimens. Dr. Antonio Webber (HUAM) supplied us with flowering material in spirit of $P$. obscurinervis. Dr. Jifke Koek-Noorman (Utrecht) is gratefully acknowledged for her useful suggestions and critical reading of the manuscript for the chapter on leaf anatomy. The SEM photographs were made by C.J.W. Hesse and B.J. van Heuven (Nationaal Herbarium Nederland, Universiteit Leiden branch).

\section{REFERENCES}

Chatrou, L.W. 1998. Changing genera. Systematic studies in Neotropical and West African Annonaceae. PhD thesis. Utrecht.

Diels, L. 1905. In: R. Pilger, Beiträge zur Flora des Hylaea nach den Sammlungen von E. Ule. Verh. Bot. Vereins Prov. Brandenburg 47: 125-136.

Diels. L. 1931. Anonaceae novae. Notizbl. Bot. Gart. Berlin-Dahlem 11: 73-86.

Doyle, J.A., P. Bygrave \& A. le Thomas. 2000. Implications of molecular data for pollen evolution in Annonaceae. In: M.M. Harley, C.M. Morton \& S. Blackmore (eds.), Pollen and spores: morphology and biology: 259-284. Royal Botanic Gardens, Kew.

Fries, R.E. 1931. Revision der Arten einiger Anonaceen-Gattungen II. Acta Horti Berg. 10: 129-341.

Fries, R.E. 1934. Revision der Arten einiger Anonaceen-Gattungen III. Acta Horti Berg. 12: $1-220$.

Fries, R.E. 1937. Revision der Arten einiger Annonaceen-Gattungen IV. Acta Horti Berg. 12: 222-231.

Fries, R.E. 1959. Annonaceae. In: H. Melchior (ed.), Die Natürlichen Pflanzenfamilien ... begründet von A. Engler und K. Prantl, ed. 2, 17aII: 1-171. Duncker \& Humblot, Berlin. 
Maas, P.J.M. 1996. Studies in Annonaceae XXX. Monograph of Duguetia: preliminary notes. Bot. Jahrb. Syst. 118: 187-227.

Maas, P.J.M. 1999. Studies in Annonaceae XXXVII. Monograph of Duguetia: preliminary notes II. Bot. Jahrb. Syst. 121: 465-489.

Maas, P.J.M., E.C.H. van Heusden, J. Koek-Noorman, A.K. van Setten \& L.Y.Th. Westra. 1986. Studies in Annonaceae VII. New species from the Neotropics and miscellaneous notes. Proc. Kon. Ned. Akad. Wetensch. C. 89: 249-278.

Maas, P.J.M. \& L.Y.Th. Westra. 1989. Studies in Annonaceae XI. Monograph of Rollinia: preliminary notes. Proc. Kon. Ned. Akad. Wetensch. C. 92: 297-324.

Maas, P.J.M., L.Y.Th. Westra \& Collaborators. 1992. Rollinia (Annonaceae). Flora Neotropica Monograph 57: 1-188. The New York Botanical Garden, New York.

Maas, P.J.M., L.Y.Th. Westra \& L.W. Chatrou. In press. Duguetia (Annonaceae). Flora Neotropica Monograph.

Metcalfe, C.R. \& L. Chalk. 1979. Anatomy of the Dicotyledons. Vol. 1. Second edition. Oxford University Press.

Metcalfe, C.R. \& L. Chalk. 1983. Anatomy of the Dicotyledons. Vol. 2. Second edition. Oxford University Press.

Murillo-A., J. \& D. Restrepo. 2000. Las Anonáceas de la región de Araracuara. Estudios en la Amazonia Colombiana XX: 143. Tropenbos Colombia.

Ribeiro, J.E.L.S., P.J.M. Maas, H. Maas, J.M. Miralha \& A.C. Webber. 1999. Annonaceae. In: J.E.L.S. Ribeiro et al. (eds.), Flora da Reserva Ducke. Guia de identificação das plantas vasculares de uma floresta de terra-firme na Amazônia Central: 121-135, 751. Instituto Nacional de Pesquisas da Amazônia, Department for International Development, Manaus.

Van Heusden, E.C.H. 1992. Flowers of Annonaceae: Morphology, classification, and evolution. Blumea Supplement 7: 1-218.

Van Setten, A.K. \& J. Koek-Noorman. 1986. Studies in Annonaceae VI. A leaf anatomical survey of genera of Annonaceae in the Neotropics. Bot. Jahrb. Syst. 108: 17-50.

Van Setten, A.K. \& J. Koek-Noorman. 1992. Fruits and seeds of Annonaceae: Morphology and its significance for classification and identification. Biblioth. Bot. 142: 1-101.

Vásquez M., R. 1997. Flórula de las Reservas Biológicas de Iquitos, Perú. Monogr. Syst. Bot. Missouri Bot. Gard. 63: 104-112, 870.

Walker, J.W. 1971. Pollen morphology, phytogeography, and phylogeny of the Annonaceae. Contr. Gray Herb. 202: 1-132.

\section{IDENTIFICATION LIST}

The abbreviations behind the collector numbers refer to the following taxa:

Pseudoxandra
acr $=$ acreana
atr $=$ atrata
bah $=$ bahiensis
bor $=$ borbensis
cau $=$ cauliflora
cus $=$ cuspidata
duc $=$ duckei
lei $=$ leiophylla
lon $=$ longipes
luc $=$ lucida
obs $=$ obscurinervis

$\begin{aligned} \text { pac } & =\text { pacifica } \\ \text { pap } & =\text { papillosa } \\ \text { par } & =\text { parvifolia } \\ \text { pil } & =\text { pilosa } \\ \text { pol } & =\text { polyphleba } \\ \text { rev } & =\text { revoluta } \\ \text { rio } & =\text { rionegrensis } \\ \text { scl } & =\text { sclerocarpa } \\ \text { spA } & =\text { spec. } A \\ \text { spi } & =\text { spiritus } \text {-sancti } \\ \text { val } & =\text { vallicola } \\ \text { wil } & =\text { williamsii }\end{aligned}$

Aguilar \& Castro 613: luc - Albuquerque \& Paula 67-16: duc - Amaral et al. 190: luc; 576: lei; 725: pol - Amorim et al. 388: bah; 795: bah; 1193: bah; 2042: bah - Anderson 11913: pol E. Arévalo 446: pol; 590: rev - N. Arévalo et al. 60: luc; 68: sp. indet.; 74: rev - Arroyo et al. 463: luc - Assunção 425: obs - Ayala et al. 4248: luc; 4283: luc; 5676: luc; 5736: luc. 
Bahia 23: cus - Belém \& Pinheiro 3252: bah - Benko-Iseppon 73: pol - Berg et al. 757: cus; P18462: luc - Bernardi 10687: val - Berry et al. 5449: lei; 6196: par; 6261: par — Boom et al. 8636: obs - Bordenave 2582: cus - Brand et al. 1504: cau - Breteler 4849: luc.

Campbell et al. 14485: cus - Capucho 560: cus - Cárdenas L. et al. 2591: scl; 4235: pol - Cardona 1302: luc; 1642: luc; 2560: luc - A.M.V. Carvalho et al. 3349: bah; 3601: bah; 3627: bah; 4592: bah - V. Carvalho et al. 120: obs - Chatrou et al. 212: luc; 213: luc; 448: luc; 449: luc - Cid et al. 30: obs; 1922: cus aff.; 3378: pol; 3390: pol; 3699: pap; 3745: lei; 3781: pap; 3921: obs; 3962: obs; 5274: pol; 5538: luc; 6934: luc; 7168: lei; 7423: luc?; 7576: obs; 8045: luc; 8151: luc; 9878: acr; 9925: pil; 10447: acr; 10570: acr - Clark 7432: lei - Clarke et al. 3069: luc; 3302: luc; 3336: luc; 4573: luc; 5024: cus; 6595: luc; 7689: luc; 7755: luc; 7778: luc; 8778: luc L. Coêlho et al. INPA3416: pol; INPA3455: pol; INPA16784: luc - L.S. Coêlho et al. 257: luc - Cogollo et al. 226: scl; 284: scl; 599: scl; 1206: scl; 3815: scl - Costa et al. 690: duc - Croat 18858: pol; 18893: pol; 19130: pol; 19243: luc - Cuatrecasas 7296: lei; 16399: lon - Cunha et al. 222: pol; 284: cau.

Daly et al. 893: pol; 3785: cus; 4424: cau; 5767: luc; 7995: pol - Davidse et al. 26804: lei; 27587: lei; 27838: lei — Davidson \& Jones 9492: pol; 9506: luc; 9617: pol; 9905: pol — Davis 102 (=Forest Dep. Brit. Guiana 2093): luc; 143: lei - Defler 19: pol; 20: pol - Devía et al. 2816: lon; 2831: lon; 2842: lon; 3242: lon; 4037: pac - C. Díaz et al. 454: luc; 656: pol — P. Díaz et al. 4: luc - Dionizia et al. 30: luc?; 191: luc - Duque-Jaramillo 2034: luc.

Espina M. \& García C. 1535: pac.

Faber-Langendoen et al. 246: val; 386: pac?; 501: lon; 507: lon; 1826: lon - Farney et al. 2018: luc - Fernández et al. 6155: cus?; 7980: luc - Ferreira 97: pol; 298: pol - Figueiredo et al. 774: pol - Foldats \& Velazco 9583: lei - Forero et al. 1347: pac; 9638: pac - Forest Dep. Brit. Guiana 2093: luc - Foster et al. 114: pol; 166: pol - Fróes 22477: pol; 26448: pol.

García C. et al. 91: pac - Garnier 6: cus - Gentry et al. 18499: pol; 18544: luc; 20332: pol; 20523: luc; 24870: luc; 24880: luc; 24908: luc; 25152: luc; 25296: atr; 28807: pol; 28941: luc; 30158: pac; 30200: pac; 30319: pac; 35509: pac; 38150: luc; 39391: pol; 40279: pac; 43103: pol; 47386: lei; 48357: val; 51554: luc; 56242: rev; 54548: pol; 57955: luc; 61898: atr; 62951: lon; 65554: lon - Gomes \& Miranda 213: luc; 501: luc - Gottsberger \& Döring 113-31186: pol; 116-12286: pol - Grández et al. 314: luc; 535: luc; 1174: luc; 1688: luc; 1878: luc; 2157: cau; 2796: cau; 5238: luc? - Grenand 951: cus; 1423: cus; 2864: cus.

Henderson et al. 355: bor; 401: pol - Henkel et al. 3147: luc; 4787: luc; 5098: luc; 5116: luc - Hernández \& Hoyos 318: scl - Hoyos et al. 304: scl; 446: scl; 448: scl; 998: scl.

Idrobo 4680: val - Irwin et al. 47819: cus; 47855: cus.

Jansen-Jacobs et al. 1660: luc; 2895: luc; 5752: luc - Jardim et al. 173: bah; 352: bah — Juncosa 2137: val.

Killeen 4459: luc - Knob et al. 509: obs - Kollmann et al. 721: spi; 911: spi; 1257: spi; 1744: spi; 1831: spi - Krukoff 4882: pol; 8131: luc; 8409: pol - Kuhlmann $463=$ RB24264: luc; $556=$ RB3421: pol; RB24252: pol.

Larazin INPA93676: obs - Lemos 4: obs - Liesner 17113: lei - Lima \& Santos 147: bah — Lister \& Colchester 678: pol - Lleras et al. P16938: luc - Loureiro et al. INPA37575: pol; INPA39564: obs.

Maas et al. 6289: luc; 6300: luc; 6338: rev; 6352: rev; 6910: rio; 7000: bah; 8215: luc; 8227: luc; 8293: luc; 8297: pol; 8833: spi; 8835: spi - Maciel et al. 379: cus; 423: cus - Maguire et al. 36523: lei - Martins et al. 15: obs - Maytahuari 793-6H: luc - McDaniel et al. 18379: pol; 20676: luc; 29894: pol - Mexia 6416: pol - Miller \& Davidse 1657: lei - Miranda et al. 448: cus - Monsalve B. 168: val; 303: lon; 464: lon; 1073: lon; 1168: lon - Monteiro 28: obs - Montero \& Divico 201: luc - Morawetz 21-18883: pol; 23-30883: pol - Mori et al. 9805: bah; 10240: bah; 10304: bah; 10309: bah; 10827: bah; 12051a: bah; 15677: cus; 15894: cus; 16197: cus; 17190a: cus; 17234: cus; 18561: cus; 24376: luc - Murillo-A. et al. 534: pol; 582: spA; 616: spA.

Oliveira et al. 424: obs; 1402: obs; 1712: obs.

T.D. Pennington et al. 16671: luc; 17137: rev - Perry et al. 624: pol - Peters 36: luc; 84-016: luc - Pipoly et al. 12942: luc; 14839: luc - J.M. Pires et al. 7926: lei?; 50444: cus - O. Pires 82: obs - Plowman et al. 2386: pol; 12350: pol - Poeppig 2638: luc; 2687: pol — Poole et al. 1969: 
luc - Prance et al. 2776: pol; 2897: pol; 2948: pol; 3511: pol; 6699: pol; 6748: pol; 6841: pol?; 11265: pol; 11468: obs; 14161: pol; 58673: cus; 58734: cus - Prévost \& Sabatier 2227: cus.

Quevedo et al. 2343: luc.

Rainer 316: luc - Ramírez \& Cárdenas L. 159: scl; 424: scl; 928: scl; 1170: scl; 1373: scl; 1472: scl; 1785: scl; 1837: scl - Ramírez C. 1095: luc - Rentería A. \& Cogollo 2710: scl - Restrepo \& Matapi 634: pol - Revilla et al. 356: luc; 1160: luc; 2490: luc; 2552: luc; 2999: luc; 3696: rev; 3754: rev - Ribamar \& Ramos 341: obs - Rimachi Y. 2310: luc; 2519: luc; 2527: pol; 2548: luc; 3283: pol; 4462: acr - J.S. Rodrigues 13: pol - W.A. Rodrigues et al. 320: luc; 738: pol; 803: pol; 1925: luc; 2271: obs; 2474: luc; 5208: obs; 5661: duc; 5916: duc; 6837: obs; 7083: duc; 7775: pol; 7815: duc; 8425: pol; INPA4430: luc - Rosa \& Santos 1788: cus; 2054: luc - Rosales \& Dezzeo 835: luc - Rosário \& das Graças 1257: pol - J.C. Ruíz et al. 1314: rev; 1440: pol; 1582: luc - Rylands 44/1980: bah.

Sabatier \& Prévost 1837: cus - Sanchez S. et al. 1393: luc - Sanoja et al. 2941: cus? - Sant'Ana et al. 555: bah - J.U. Santos et al. 217: luc - M.P.S. Santos et al. 20: pol - M.R. Santos 1: pol; 54: pol - T.S. Santos et al. 4180: bah; 4237: bah - Schultes \& Cabrera R. 17009: pap - Setz 298: obs - A.S.L. Silva et al. P25777: pol - L.A.M. Silva et al. 952: bah; 2593: bah; 4180: bah - M. Silva 793: pol - M.F. Silva et al. 1315: luc - M.G. Silva \& Bahia 3556: cus A.C. Smith 2665: luc - M.A.D. Souza et al.302: obs - S.A.M. Souza et al. 366: luc - Spichiger \& Encarnación 1163: luc - Spruce 2473: lei; 3353: lei - Stergios \& Aymard 7537: lei Stevenson et al. 898: rio - Steyermark \& Delascio C. 129373: luc.

Tavares et al. 466: obs - Thomas et al. 3496: lei; 5087: luc?; 5433: luc; 7046: bah; 7299: bah; 7359: bah; 10682: bah; 11509: bah; 12172: bah — Thomaz 785: spi; 1289: spi; 1846: spi.

Ule 5004: pol; 5007: pol; 5628: pol - Urrego G. et al. 1040: atr; 1371: lei.

Van der Werff et al. 10065: luc; 15457: luc - Van Dulmen et al. 5: pol; 61: pol; 282: lei - Van Rooden et al. 565: pac? - Vásquez et al. 119: luc; 284: pol; 2177: rev; 4110: luc; 4302: luc; 4373: luc; 5389: luc; 6674: luc; 7359: luc; 7495: luc; 7988: luc; 10013: rev; 10240: luc; 10340: pol; 11727: pol; 12501: luc; 14419: atr; 16172: pol; 16888: atr - Velazco 1720: par - Vicentini et al. 703: obs - Vinha \& Pinheiro 79: bah.

Webber et al. 747: pol - Ll. Williams 113: luc; 3960: wil - Wurdack \& Adderley 43264: lei; 43492: lei.

Yanez 505: luc.

Zarucchi 2155: lei.

\section{INDEX TO SCIENTIFIC NAMES}

Accepted taxa are in roman type, new taxa in bold and synonyms in italics. Numbers refer to the species number as used in this revision.

Cremastosperma guianense R.E. Fr. 10 polyphleba (Diels) R.E. Fr. 16

williamsii R.E. Fr. 22

Malmea cuspidata Diels 10

Pseudoxandra R.E. Fr. [p. 205]

acreana Maas 1

atrata Maas 2

bahiensis Maas 3

borbensis Maas 4

cauliflora Maas 5

coriacea R.E. Fr. 8

cuspidata Maas 6

duckei Maas 7

guianensis (R.E. Fr.) R.E. Fr. 10

leiophylla (Diels) R.E. Fr. 8

longipes Maas 9

lucida R.E. Fr. 10
(Pseudoxandra)

obscurinervis Maas 11

pacifica Maas 12

papillosa Maas 13

parvifolia Maas 14

pilosa Maas 15

polyphleba (Diels) R.E. Fr. 16

revoluta Maas 17

rionegrensis Maas 18

sclerocarpa Maas 19

spiritus-sancti Maas 20

vallicola Maas 21

williamsii (R.E. Fr.) R.E. Fr. 22

spec. A 23

Unonopsis leiophylla Diels 8

polyphleba Diels 16 